ASD Techntcal Report 61-233

\title{
HIGH TEMPERATURE OXIDATION RESISTANT COATINGS FOR TANTALUM BASE ALLOYS
}

\author{
Dean D. Lawthers \\ L. Sama \\ Sylcor Division
}

sylvania Electric Products, Inc.

Directorate of Materials and Processes Contract No, AF 33(616)-7462

Project No. 7351

Task No。 73512

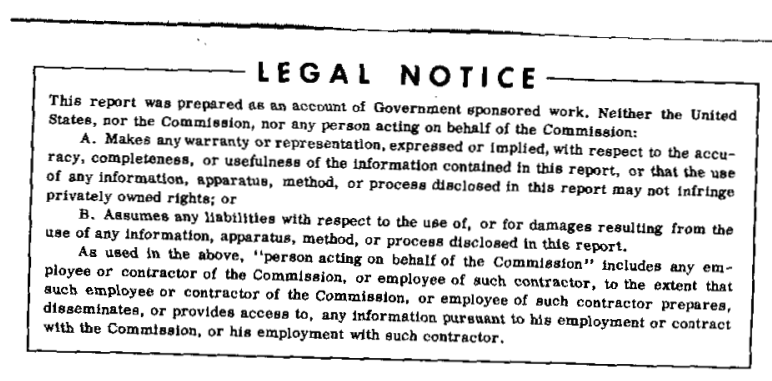

AERONAUT ICAL SYSTEMS DIVIS ION

AIR FORCE SYSTEMS COMMAND

UNITED STATES AIR FORCE

WR IGHT-PATTERSON AIR FORCE BASE, OHIO 


\section{DISCLAIMER}

This report was prepared as an account of work sponsored by an agency of the United States Government. Neither the United States Government nor any agency Thereof, nor any of their employees, makes any warranty, express or implied, or assumes any legal liability or responsibility for the accuracy, completeness, or usefulness of any information, apparatus, product, or process disclosed, or represents that its use would not infringe privately owned rights. Reference herein to any specific commercial product, process, or service by trade name, trademark, manufacturer, or otherwise does not necessarily constitute or imply its endorsement, recommendation, or favoring by the United States Government or any agency thereof. The views and opinions of authors expressed herein do not necessarily state or reflect those of the United States Government or any agency thereof. 


\section{DISCLAIMER}

Portions of this document may be illegible in electronic image products. Images are produced from the best available original document. 


\section{FOREWORD}

This report was prepared by Sylcor Division, Sylvania Electric Products, Inc. under USAF contract No. AF33(616)-7462. This contract was initiated under Project No. O(7-7351), Task No. 73512. The work was administered under the direction of the Directorate of Materials and Processes, Deputy for Technology, Aeronautical Systems Division, with Mr. N. M. Geyer acting as project engineer.

This report covers work conducted from 1 June 1960 to 31 May 1961。

The program was carried out under the direction of Mr. L. Sama. The work was supervised by Mr. D. D. Lawthers. The aluminum coating phase was performed by Mr. G. T. Pepino, Jr., beryllium coating phase by Mr。D. Melone, hardness and flame oxidation testing by Mr. O. Haines, and metallography by Mr. H. Woods。 
Aluminide and beryllide coatings were investigated for pure tantalum, a commercial Ta-lo W alloy, and a ternary alloy under development。 Coatings were applied by dipping, packing, cold spraying, and vapor deposition. Oxidation resistance was evaluated by furnace testing, resistance heating, and flame testing. Internal hardening and diffusion effects were also studiedo A Sn-Al coating was developed, which has excellent oxidation resistance for lo hours to at least $3000^{\circ} \mathrm{F}$. Evaluation was successfully extended to arcplasma tests which also showed the feasibility of protecting molybdenum and tungsten. A similar but minor effort investigation was performed with a columbium alloy which could be protected to $2500^{\circ} \mathrm{F}$ for at least 10 hours. 
TABLE OF CONTENTS

PAGE

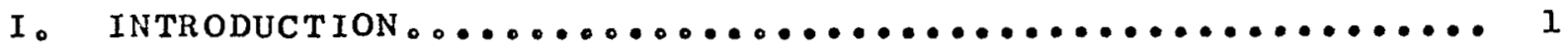

A. Materials............................... 2

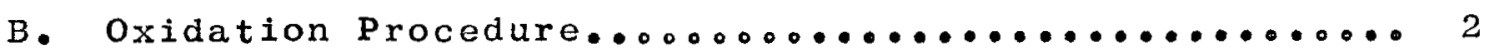

C. Coating Techniques......................... 6

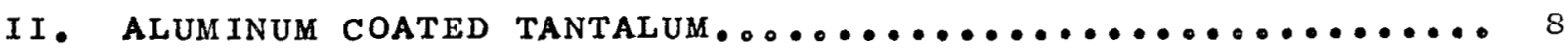

A. Compound studies.......................... 20

B. Oxidation Results............................. 21

C. Metallographic Results on Al Coatings............ 23

III。 TIN-ALUMINUM COATINGS........................ 28

A. Dip Coating................................ 23

B. Spray coating............................. 36

C. Battelle Alloys.............................. 40

D. Bend Ductility and Diffusion Rates..............4 40

E. Oxidation Rates............................. 45

F. Electrically Heated Oxidation Data............. 53

G. Creep Oxidation............................ 53

H. Flame Oxidation Tests...................... 53

I. Arc Plasma Tests............................ 56

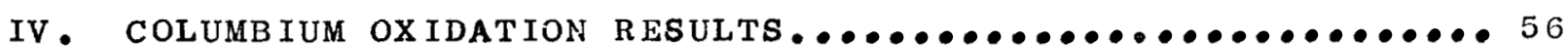

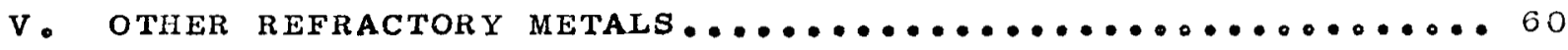

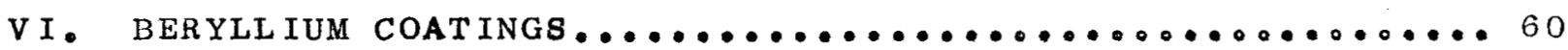

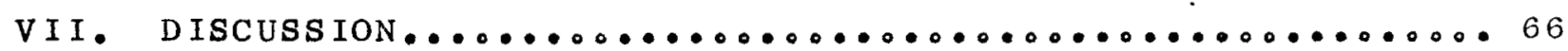

VIII. SUMMARY $\ldots \ldots \ldots \ldots \ldots \ldots \ldots \ldots \ldots \ldots \ldots \ldots \ldots \ldots \ldots \ldots \ldots \ldots \ldots \ldots \ldots \ldots \ldots \ldots \ldots \ldots . \ldots 72$

IX. REFERENCES ................................ 73 


\section{IST OF F IGURES}

F IGUR E

PAGE

1 Direct resistance tensile specimen ...............

2 Electrically heated oxidation test apparatus.........

3 Schematic of electrically heated oxidation test

apparatus................................... 5

4 Flame oxidation test rig $\ldots \ldots \ldots \ldots \ldots$

5 Aluminum coated tantalum sheet as dipped 1 minute

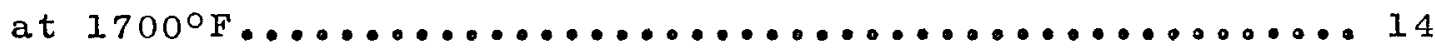

6 Aluminum coated tantalum sheet dipped for 1 minute at $1700^{\circ} \mathrm{F}$, vacuum diffused....................15

7 Aluminum coated tantalum sheet dipped 1 minute at

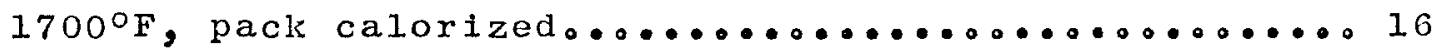

8 Aluminum coated tantalum sheet dipped for 1 minute at $1700^{\circ} \mathrm{F}$, pack calorized...................... 17

9 Effect of oxidation time and temperature on 90 A1-

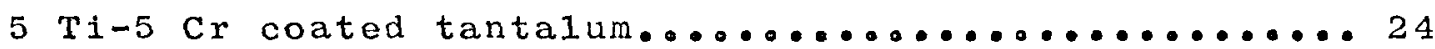

$9 b \quad$ Oxidized 10 hours at $2500^{\circ} \mathrm{F} \ldots \ldots \ldots \ldots$

9c Oxidized 10 hours at $2700^{\circ} \mathrm{F} \ldots \ldots \ldots \ldots \ldots \ldots$

9d Oxidized 10 hours at $2800^{\circ} \mathrm{F} \ldots \ldots \ldots \ldots \ldots$

10 Effect of time on core thickness and internal hardening of samples dip coated with Al-5 Cr-5 Ti....... 29

$1190 \%$ tin-10\% (AI-10 Si) coated tantalum after oxi-

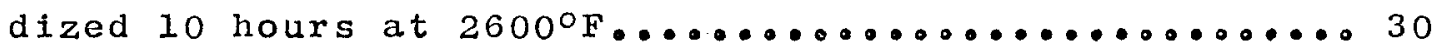

12 Effect of diffusion temperature on $90 \%$ tin-10\%

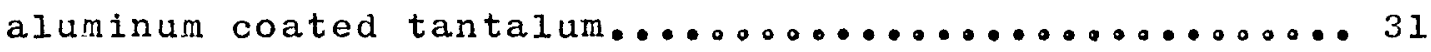

$1390 \% \mathrm{sn}-10 \%$ AI coated tantalum twisted into a knot..... 32 


\section{LIST OF FIGURES (Cont $\left.{ }^{2} \mathrm{~d}_{\bullet}\right)$}

F IGURE

PAGE

14 Effect of time on core thiclness and internal

hardening of samples dip coated with sn-lo Al....... 34

15 Spray coated four times and vacuun diffused

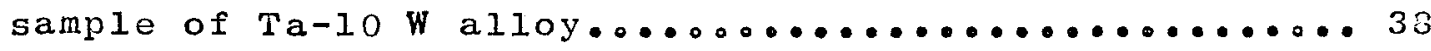

16 As coated and oxidized 10 hours at $2700^{\circ} \mathrm{F}$. Sample

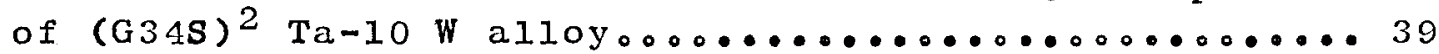

17 Overall view of bend area, oxidized sixteen hours at $2600^{\circ} \mathrm{F}$ - Coating Sn-10 Al dip...............45

13 Weight gains of $34 \mathrm{~S}$ coated Ta-10 W alloy samples

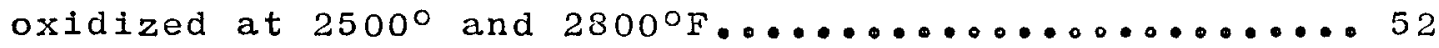

19 Beryllium coated samples after oxidation for ten hours................................... 70 


\section{LIST OF TABLES}

TABLE

PAGE

1 Thickness of Aluminum Coatings on Tantalum Sheet...... 9

2

Coating Compositions.......................... 18

Thickness of Sprayed and Diffused Sn-Al Coating on

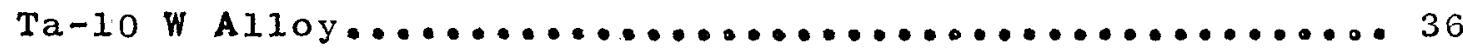

4 Furnace Oxidation Results on Multi-Sprayed Sn-Al

Coated Ta-10 W Alloy at $2600^{\circ} \mathrm{F} \ldots \ldots \ldots \ldots \ldots \ldots \ldots \ldots \ldots \ldots \ldots$

5 Furnace Oxidation Results on 34 S Coated Ta-10 W Alloy。. 41

6 Furnace Oxidation Results on Coated Battelle Alloy

sheet.................................... 44

7 Diffusion Effects on G21 Coated Tantalum Materials_o.. 47

8 Diffusion Effects on 348 Coated Tantalum Materials.... 49

9 Oxidation Weight Change of 34 S Coated Ta-10 W Alloy.... 51

10 Direct Resistance Heated Oxidation Results on $34 \mathrm{~S}$

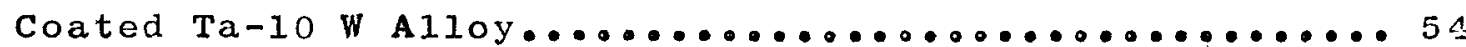

11 Creep Results on Coated Ta-10 W Alloy.............. 55

12 Flame Oxidation Test Results on Coated Ta-10 W Alloy...57

13 Arc-Plasma Test Schedule on 348 Coated Ta-10 W Alloy... 59

14 Oxidation Results on Coated Columbium Alloys........61

15 Oxidation Results on Coated Molybdenum and Tungsten....63

16 Metallographic Thickness of Beryllide Coatings.......664

17 Growth of Tantalum Beryliides................... 65

18 Furnace Oxidation Results on Beryllide Coated

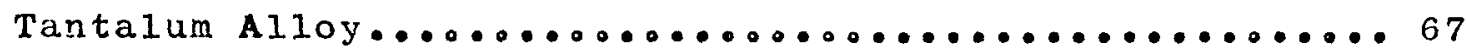

vi i 


\section{HIGII TEMPERATURE OXIDATION RESISTANT COATINGS FOR TANTALUM BASE ALLOYS}

\section{INTRODUCTION}

The development of tantalum base alloys with attractive high temperature mechanical properties has been quite recent( 1 ) and begins to make tantalum and its alloys appear promising for high temperature use, such as re-entry vehicles. Its high cost and density are somewhat offset by excellent ductility and fabricability. As with the other refractory metals tantalum has poor elevated temper ature oxidation resistance(2), especially in the range $2000^{\circ}-3400^{\circ} \mathrm{F}$ where it may be expected to be useful. Therefore, the need for protective coatings is evident.

The program was intended to approach coating development from a fundamental viewpoint. Since tantalum alloys are contemplated for use in a variety of applications, coatings were not to be developed for any specific utilization, but rather to be sufficiently characterized to perint evaluation for the several potential applications. The capabilities of all experimental coatings were to be determined by subjecting coated tantalum specimens to at least the following evaluation tests:

1. Continuous isothermal exposure in air at temperatures from $2500^{\circ}$ to $2800^{\circ} \mathrm{F}$ for a minimum of 10 hours.

2. Withstand at least 10 cycles during 10 hours in an air blast between test temperature (25000 to $\left.2800^{\circ} \mathrm{F}\right)$ and ambient.

3. The coating had to withstand $2 \%$ deformation at terperature without causing oxidation failure.

The specific approach to be employed in developing oxidation resigtant coatings was to base such coatings on intermetallic compounda of tantalum. Aluminides and berylifies were known to have this required oxidation resistance( 3$)$ and the intent was to meet the objectives by producing a two mil (0.002") coating of these compounds on the surface.

Another requirement was to use gimple coating techniques since complex shapes or large pieces might be required in practical applications.

Manuscript released by authors August 1901 for publication as an AsD Technical Report. 
A. Materials

Coatings were evaluated on three tantalum base alloys: (1) pure tantalum; (2) a commercial Ta-lo $\mathrm{W}$ alloy; and (3) $\mathrm{Ta}-10$ Hf-5 W alloy which was produced by Battelle Memorial Institute. since some re-entry vehicles require thin sheets and to magnify diffusion effects, $0.010^{\prime \prime}$ thick sheet was used for the investigation. Alloys were coated in the steel grit-blasted, cold rolled, as-received condition. The corners and edges of the sample were not rounded. Several size samples were used for different testing techniques.

\section{B. Oxidation Procedure}

To obtain oxidation results three different methods of heating were used. The most used technique was by electrically heating by direct resistance, sheet tensile type samples as shown in Figure 1. one of the four heating units is shown in Figure 2, and a schematic sketch in Figure 3. Current was fed to the sample through copper clamps. The lower clamp makes contact in a pool of mercuryo Maximum current was 55 amperes for these units and the standard $2500^{\circ} \mathrm{F}$ test only requires about 100 watts. The temperature was measured with an optical pyrometero oxidation tests could be made either isothermally or by thernal cycling to room temperature with an air blast flowing, both under tensile loads. All compositions are given in weight percent in this report. The standard test sample was measured for width and thickness, the length between holes recorded to 0.0001" for strain purposes (length of hot zone was $\left.0.40^{\prime \prime}\right)$, and the testing units programed for 10 hours oxidation time with 55 minutes between cycles (could be varied between 1 and 60 minutes).

A cycle consists of turning the power off and having the air blast hitting the sample for ten seconds before the current comes back on. This time could and was varied up to 30 seconds with no difference noted on oxidation behavior. Therefore, a ten second interval was arbitrarily selected. If the sample failed prematurely, a microswitch was actuated and shuts all power off. A normal 12 hour clock indicates the time of failure。

It is known that this type of heating has certain inherent disadvantages such as:

1. The inside is hotter than the surface, 
c

$+1$

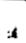

4

c

$\omega$

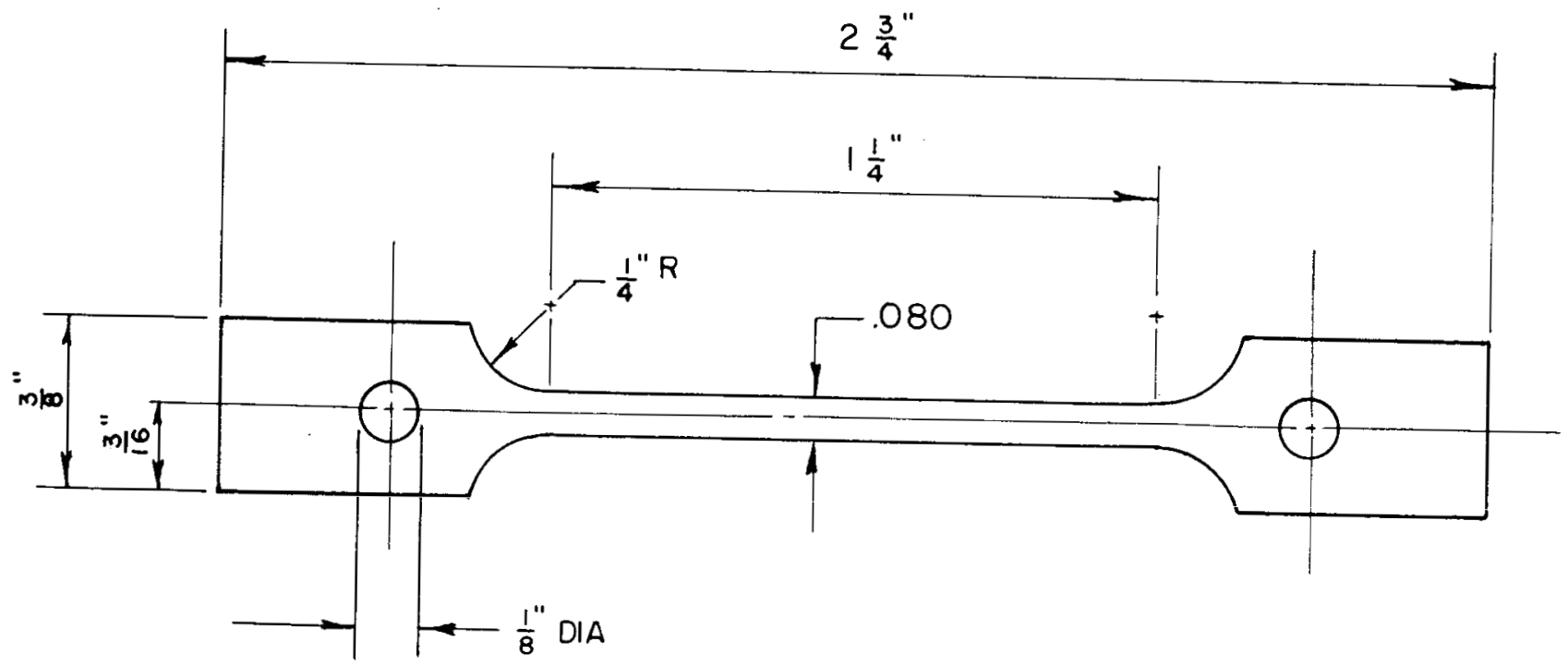

$F$

Scale $2 x$

Fig 。 1. Direct resistance tensile spocimon。 


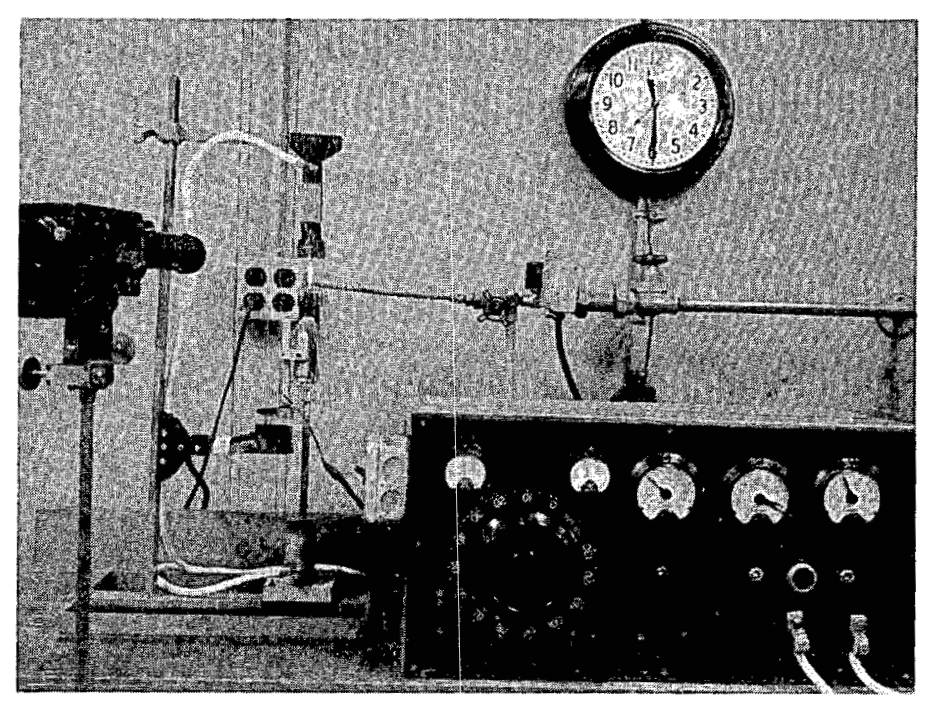

Fig. 2. Electrically heated oxidation test apparatus. 

(A) HR. CLOCK
(E) AMMETER
(1) STRAIN INDICATOR
(B) MIN. CLOCK
(F) VARIAC
(C) SEC.CLOCK
(G) SWITCHES
(D) VOLTMETER
(H) AIR BLAST
(J) WEIGHT PAN
(k) SAMPLE
(L) CLAMPS

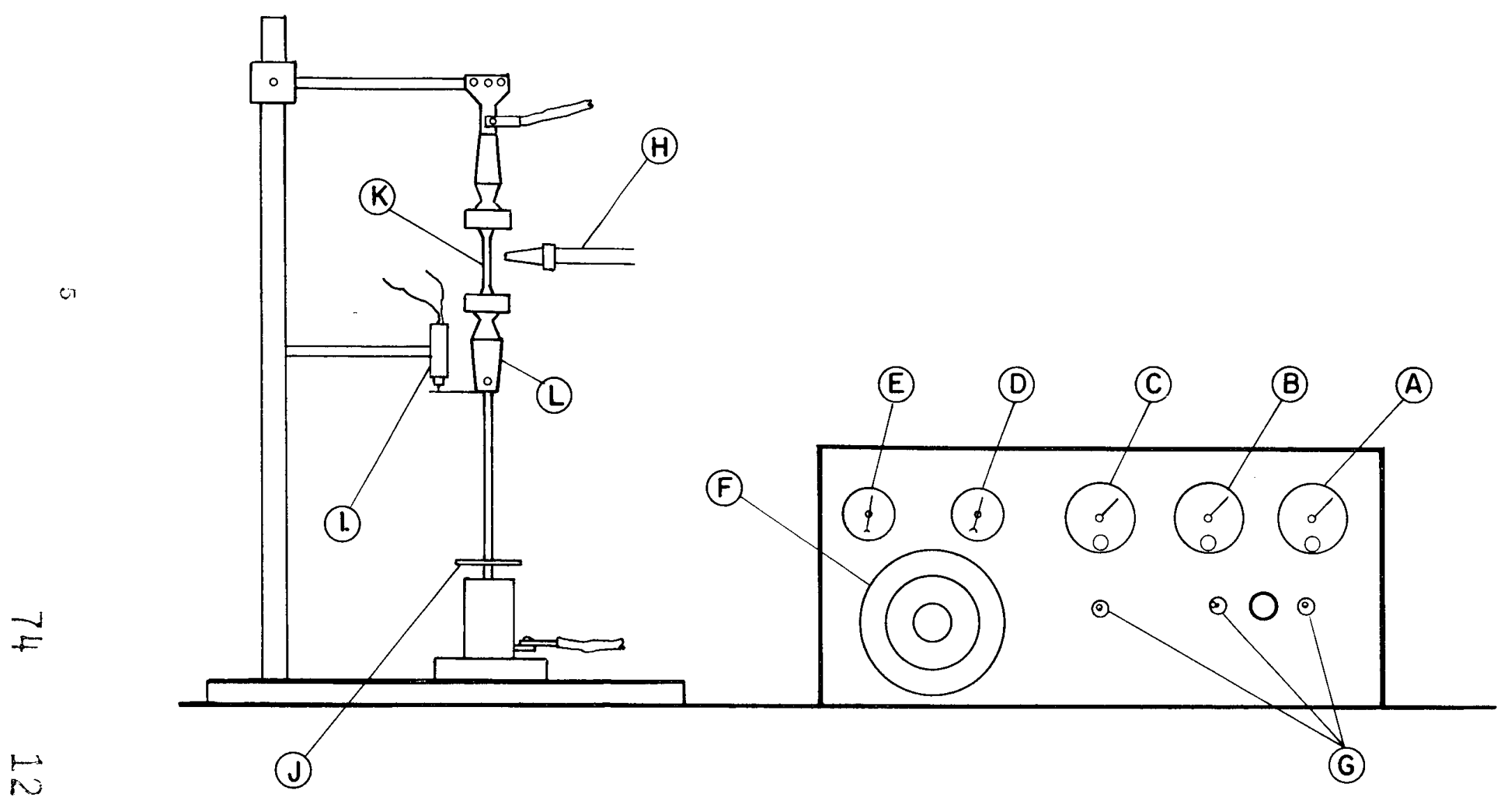


2. The emissivity of the surface can change as a function of
time,

3. Any change that decreases current carrying area increases temperature and accelerates oxidation, and

4. Heating is from the inside out rather than from the outside as would be the case in actual use.

However, if good correlation could be found between furnace tests and direct resistance heating results, the advantage of economy, ease and flexibility of testing, visual observation of oxidation, and multiplicity of results from one test clearly outweigh the disadvantages. This type of oxidation test procedure gave a comparable evaluation of different coatings.

The second method of oxidation testing was to heat a 2 " long $x I^{\prime \prime}$ wide $x$ 0.010" thick piece of coated tantalum in an oxygen-gas flame. Again the temperature was measured by an optical pyrometer. The sample was cycled in an air blast. A sketch of the apparatus is given in Figure 4 。

The third and most conventional manner of oxidation testing used was with coated 3/4" $x 1 / 2 " x 0.010 "$ coupons in a furnace with slowly moving air. The samples could be removed periodically for thermal cycling and visual observation.

\section{Coating Techniques}

Tantalum aluminide type coatings were produced by a number of different techniques as follows:

1. Vacuum or argon pack calorized using fine elemental powders, $\mathrm{Al}_{2} \mathrm{O}_{3}$, with or without a carrier such as $\mathrm{NH}_{4} \mathrm{Cl}$;

2. Dipping in a molten aluminum alloy bath with or without a subsequent pack calorizing heat treatment;

3. Slurry painting with metal powders in a nitro-cellulose lacquer followed by a vacuum diffusion heat treatment;

4. Spraying the slurry followed by vacuum heat treatment; or

5. Combinations of the above。 

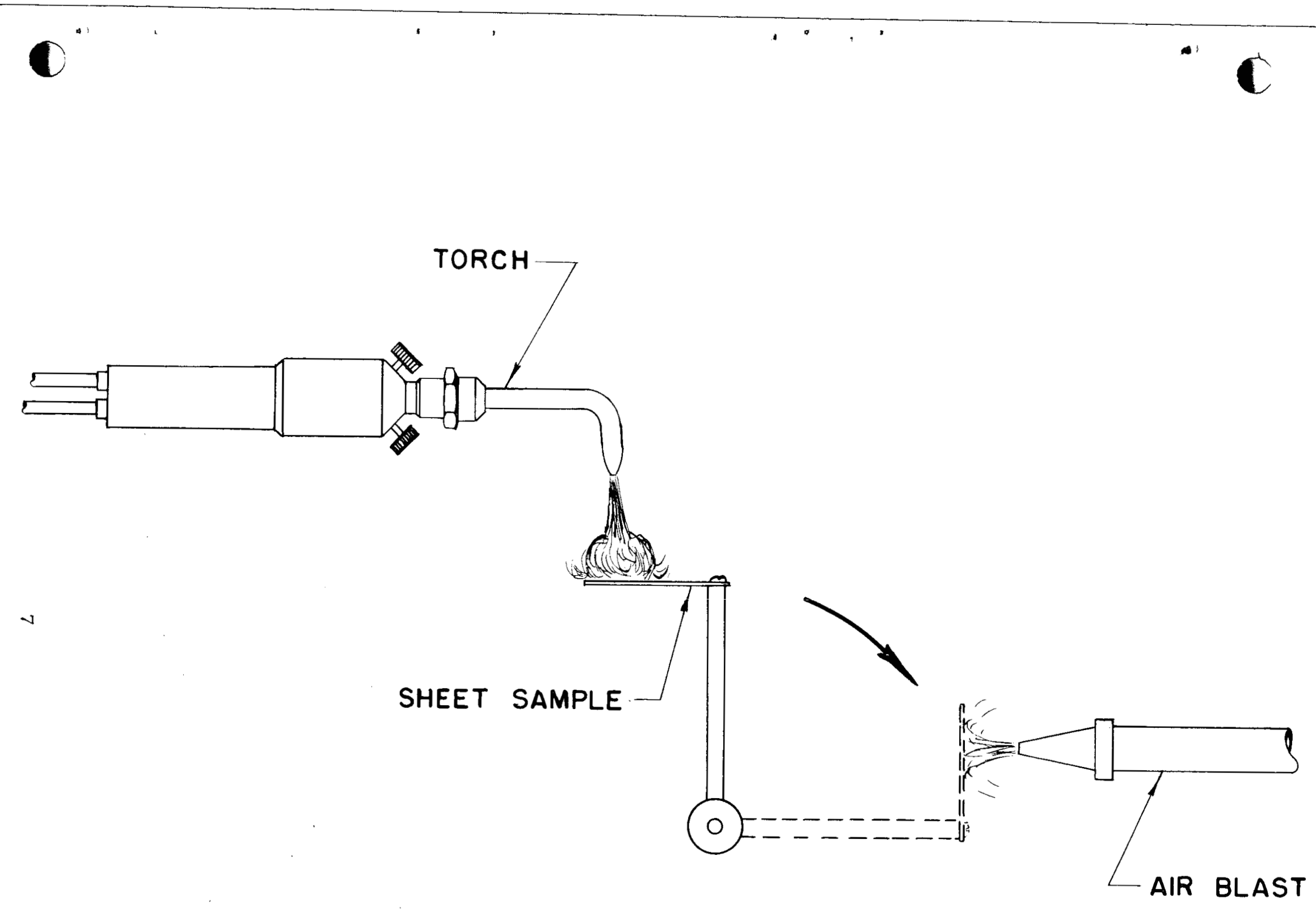

$\stackrel{1}{F}$

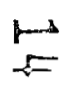

Fig。 4. Flame oxidation test rig. 
It must be emphasized that coating compositions were varied mainly to suit a particular method of application and to obtain maximum oxidation characteristics. In all cases the end product desired was the tri-aluminide or aluminide plus excess tin coating.

\section{I • ALUMINUM COATED TANTALUM}

Tine first step in the program was to investigate the formation of tantalum aluminide by hot dipping in molten aluminum and aluminum base alloys with and without subsequent reaction-diffusion treatment at elevated temperatures in inert atmospheres.

To determine the effect of dipping variables on coatings, the following program was established:

1. Dip in molten aluminum and aluminum alloys at $1700^{\circ}$ and $2100^{\circ} \mathrm{F}$ for 1,2 , and 5 minutes followed by

2. A vacuum diffusion heat treatment, or

3. A pack calorizing heat treatment in Al or Al alloy plus $\mathrm{Al}_{2} \mathrm{O}_{3}$ powders at $1900^{\circ}$ and $2200^{\circ} \mathrm{F}$ for $\mathrm{I}$ and 4 hours。

All results on pure tantalum were obtained using annealed sheet. The test coupons were $0.5^{\prime \prime} \times 0.75^{\prime \prime} \times 0.010^{\prime \prime}$ 。

Samples were dipped in four baths: G3 pure aluminum, G4 A1-11 Si, G5 Al-10 Si-10 Cr, G6 Al-25 Si. The effect of test variables on coating thickness and solution of the tantalum core is given in Table 1. All measurements were made on metallographic samples. The original thickness of the tantalum sheet is $9.7 \mathrm{mils}\left(0.0097^{\prime \prime}\right)$. The following statements can be nade based on these results:

1. Using an aluminum bath, varying dipping time and temperature has no significant effect on the thickness of coating, which was one mil per side, but the tantalum core was dissolved away rapidly with increasing time and temperature.

2. A vacuum heat treatment cannot be used on dipped tantalum specimens because of the rapid vaporization of free aluminum before the intermetallic tantalum aluminide is formed. 
TABLE I.

TH ICKNESS OF ALUMINUM COATINGS ON TANTALUM SHEET

Dipping

Temper

1700
1700
1700
2100
2100

Time, Mine

Thickness in mils

\section{Pure Aluminum Dip. As Dipped}

Coating Total

$\begin{array}{rrrr}1 & 1.3 & 9.3 & 11.9 \\ 2 & 1.3 & 9.1 & 11.7 \\ 5 & 1.2 & 8.9 & 11.3 \\ 1 & 1.7 & 8.6 & 12.0 \\ 2 & 1.2 & 6.3 & 3.7\end{array}$

Vacuum Diffused $1900^{\circ} \mathrm{F} \quad 1$ hour

$\begin{array}{rrrrrr}1700 & 1 & 1.4 & 8.4 & 1.7 & 11.5 \\ 1700 & 2 & 1.4 & 8.4 & 1.6 & 11.4 \\ 1700 & 5 & 1.2 & 7.6 & 1.2 & 10.7 \\ 2100 & 1 & 1.1 & 7.6 & 1.2 & 9.9 \\ 2100 & 2 & 1.3 & 7.3 & 1.3 & 9.9\end{array}$

Vacuum Diffused $1900^{\circ}$ F 4 hours

$\begin{array}{rrrrrr}1700 & 1 & 1.2 & 8.3 & 1.2 & 10.7 \\ 1700 & 2 & 1.2 & 8.3 & 1.2 & 10.7 \\ 1700 & 5 & 1.2 & 8.3 & 1.2 & 10.7 \\ 2100 & 1 & 1.0 & 7.8 & 1.2 & 9.8 \\ 2100 & 2 & 0.62 & 7.1 & 1.2 & 8.3\end{array}$

Vacuum Diffused $2200^{\circ} \mathrm{F} \quad 1$ hour

1700

1700

1700

2100

2100

1700

1700

1700

2100

2100
1.1

1.1

1.1

0.99

0.76

2
$8 \cdot 4$

8.4

8.4

$7 \cdot 7$

6.4
10.6

10.6

10.6

9.7

$7 \cdot 6$

Vacuum Diffused $2200^{\circ} \mathrm{F}$ 4 hours

$\begin{array}{llllr}1 & 1.0 & 8.2 & 1.0 & 10.3 \\ 2 & 1.0 & 8.4 & 0.74 & 10.1 \\ 5 & 0.74 & 8.2 & 0.49 & 9.4 \\ 1 & 0.49 & 7.9 & 0.44 & 8.8 \\ 2 & 0.45 & 6.9 & 0.45 & 7.8\end{array}$


TABLE 1 (Cont $\left.{ }^{2} \mathrm{~d}_{\bullet}\right)$

THICKNESS OF ALUMINUM COATINGS ON TANTALUM SHEET

Dipping

Temper of Time

1700
1700
1700
2100
2100

Thickness in mils

Coating Core coating Total

Pack Calorized $1900^{\circ} \mathrm{F}$ I hour

1

2

5

1

2

Pack Calorized $1900^{\circ} \mathrm{F}$ \& hours

1700

1700

1700

2100

2100

1700

1700

1700

2100

2100

1700

1700

1700

2100

2100
1

2

5

1

2
1.9
2.1
2.1
1.9
2.5

8. 1

7.9

7.8

7.4

6.2

7.7

7.8

7.9

7.4

6.8
Pack Calorized $2200^{\circ} \mathrm{F}$ I hou

$\begin{array}{lll}1 & 1.6 & 7.8 \\ 2 & 1.7 & 7.7 \\ 5 & & 7.7 \\ 1 & & 7.2 \\ 2 & & 5.8\end{array}$

Pack Calorized $2200^{\circ} \mathrm{F} 4$ hours
1. 9

1. 7

1. 7

2.0

2. 2
11.9

11.7

11.6

11.3

10.9

$\begin{array}{rrrrr}1 & 1.7 & 7.4 & 2.0 & 11.1 \\ 2 & 2.0 & 7.3 & 1.9 & 11.2 \\ 5 & 1.4 & 7.7 & 1.4 & 10.5 \\ 1 & 1.4 & 6.9 & 1.6 & 9.9 \\ 2 & 1.7 & 6.2 & 1.7 & 9.6\end{array}$

A1-11 Si Dip Vacuum Diffused $1900^{\circ} \mathrm{F}$ I hour

1700

1700

1700

2000

2000

1
2
5
0.5
1

1

\begin{abstract}
1.7
0.74

0.37

1.4

2.1
\end{abstract}

10
$2 \cdot 0$

11.8

10.9

10.3

10.2

9.4

. 6

1. 3

.


TABLE 1 (Cont'd.)

THICKNESS OF ALUM INUM COATINGS ON TANTALUM SHEET

Dipping

\begin{tabular}{|c|c|c|c|c|c|}
\hline \multicolumn{2}{|r|}{$\mathrm{ng}$} & \multicolumn{4}{|c|}{ hickness in mils } \\
\hline Temper $O F$ & Time, Mine & Coating & Core & Coating & Total \\
\hline \multicolumn{6}{|c|}{ Vacuum Diffused $1900^{\circ} \mathrm{F}$ 4 hours } \\
\hline 1700 & 1 & 1.3 & 8.3 & 1.0 & 10.6 \\
\hline 1700 & 2 & 0.49 & 8.2 & 0.49 & 10.1 \\
\hline 1700 & 5 & 0.4 & $8 \cdot 7$ & 0.4 & 9.5 \\
\hline 2000 & 0.5 & 1.6 & $7 \cdot 7$ & 1.4 & 10.1 \\
\hline 2000 & 1 & 0.3 & 6.9 & 2.7 & $12 \cdot 6$ \\
\hline
\end{tabular}

Vacuug Diffused $2200^{\circ} \mathrm{F} \quad 1$ hour

$\begin{array}{llllll}1700 & 1 & 1.0 & 8.1 & 1.0 & 10.1 \\ 1700 & 2 & 1.0 & 8.2 & 1.0 & 10.2 \\ 1700 & 5 & 1.1 & 8.4 & 1.0 & 10.5 \\ 2000 & 0.5 & 1.4 & 8.2 & 1.2 & 10.8 \\ 2000 & 1 & 2.6 & 7.1 & 2.5 & 12.2\end{array}$

Vacuum Diffused 2200F 4 hours

$\begin{array}{rllllr}1700 & 1 & 2.0 & 7.2 & 2.0 & 11.2 \\ 1700 & 2 & 1.2 & 8.1 & 2.1 & 11.4 \\ 1700 & 5 & 0.74 & 8.3 & 0.74 & 9.7 \\ 2000 & 0.5 & 1.2 & 7.8 & 1.2 & 10.2 \\ 2000 & 1 & & 9.1 & & \end{array}$

Pack_Calorized 1900

$\begin{array}{llllll}1700 & 1 & 1.9 & 7.6 & 1.9 & 11.4 \\ 1700 & 2 & 2.2 & 7.4 & 2.1 & 11.7 \\ 1700 & 5 & 2.2 & 7.4 & 2.0 & 11.6 \\ 2000 & 0.5 & 2.0 & 7.8 & 1.9 & 11.7 \\ 2000 & 1 & 2.0 & 7.4 & 1.9 & 11.3\end{array}$

Pack Calorized $1900^{\circ} \mathrm{F} 4$ hours

$\begin{array}{llllll}1700 & 1 & 2.5 & 7.4 & 2.0 & 11.9 \\ 1700 & 2 & 2.2 & 7.7 & 2.0 & 11.9 \\ 1700 & 5 & 1.9 & 7.7 & 1.4 & 11.0 \\ 2000 & 0.5 & 1.4 & 7.8 & 1.7 & 10.9 \\ 2000 & 1 & 2.7 & 6.8 & 3.0 & 12.5\end{array}$


TABLE I (Cont'd.)

THICKNESS OF ALUMINUM COATINGS ON TANTALUM SHEET

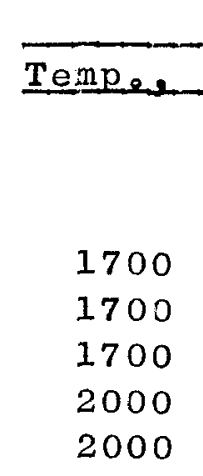

1700

1700

1700

2000

2000
Dipping OF
Time, Mine
Thickness in mils

Coating core coating Total

Pack Calorized $22000^{\circ} \mathrm{F}$ I hour

$\begin{array}{lllll}1 & 2.9 & 7.4 & 3.0 & 13.3 \\ 2 & 5.2 & 5.0 & 5.1 & 15.3 \\ 5 & 2.2 & 7.4 & 2.2 & 11.8 \\ 0.5 & 1.4 & 7.6 & 1.2 & 10.2 \\ 1 & 1.9 & 7.2 & 2.0 & 11.1\end{array}$

Pack Calorized 2200\% 4 hours

$\begin{array}{lllll}1 & 2.5 & 7.2 & 2.4 & 12.1 \\ 2 & 2.9 & 6.7 & 2.7 & 12.3 \\ 5 & 2.5 & 6.3 & 2.5 & 11.8 \\ 0.5 & 2.5 & 7.0 & 2.4 & 11.9 \\ 1 & 2.6 & 6.5 & 2.5 & 11.6\end{array}$

Al-10 \&1-10 Cr Dip, Pack Calorized 1900\% 1 hour

1700

1700

2000

2000

1700

1700

2000

2000

$\begin{array}{ll}1 & 2.0 \\ 2 & 2.6 \\ 0.5 & 1.7 \\ 1 & 3.7\end{array}$

2.0

1.7

3.7

1

$\begin{array}{lll}1 & 2.2 & 6.8 \\ 2 & 1.6 & 6.8 \\ 0.5 & 2.0 & 7.4 \\ 1 & 3.3 & 6.2\end{array}$

7 . 4

7.4

7.4

5.7

1.9

0.49

1.4

4.0

11.3

10.5

10.5

13.4

\section{Al-25 Si Dip, Pack Calorized 1900대 hour}


3. Therefore, a pack calorizing heat treatment in argon, for example, must be used in order to form tantalum aluminide $\left(\mathrm{TaAl}_{3}\right)$ on the surface。 Pack calorizing consists of placing the dipped sample in a powder mixture of $10 \mathrm{Al}$, balance $\mathrm{Al}_{2} \mathrm{O}_{3}$, heating to some temperature, say $1900^{\circ} \mathrm{F}$, for 1 hour in an argon atmosphere to react and diffuse free aluminum to form $\mathrm{TaAl}_{3}$ type compounds.

4. Dipping in AI-1I Si results in a better coating than Al. The reaction rate was much faster than with $A I$ and the growth rate of the aluminide coating is time and temperature dependent.

5. A 2 mil coating seems to be needed for oxidation resistance under the test conditions. This will be discussed further。

Photomicrographs and hardness values for aluminum coated tantalum samples dipped for 1 minute at $1700^{\circ} \mathrm{F}$ with various diffusion treatments are given in Figures 5 to 8 . Ideally under equilibrium conditions there should be three intermetallic compounds in the $\mathrm{Ta}-\mathrm{Al}$ system, $\mathrm{TaAl}_{3}$ on the outer surface, then $\mathrm{Ta}_{2} \mathrm{AI}$ and $\mathrm{Ta}{ }_{3} \mathrm{AI}$ adjacent to the tantalum core. The latter two compounds cannot be easily separated in the microstructure. Microstructures using other dipping baths of aluminum alloys are very similar. Figure 5 shows the unreacted aluminum on the tantalum surface. There is an unresolved zone of $\mathrm{TaAl}_{3}$ between the tantalum and the aluminum coating. Figures 6 to 8 reveal the growth of Ta-Al compounds as a function of time, temperature, and type of heat treatment. parts of Figures 7 and 8 were taken under polarized light to show how optically active $\mathrm{TaAl}_{3}$ is. It became known from subsequent work that $\mathrm{TaAl}_{3}$ must be present initially to confer elevated temperature oxidation resistance。

A total of over 50 different aluminum compositions and/or application methods were investigated in this study. These are listed in Table 2 . One general conclusion can be made at this point which will be proved by experimental eyidence: only those aluminum compositions that contain tin will form the most satisfactory protective oxidation resistant coatings on tantalum. A double coating-diffusion process is also necessary for maximum protection.

Of all of the tin-free aluminum compositions probably only one could have practical significance. That would be the 90 AI-5 Ti-5 


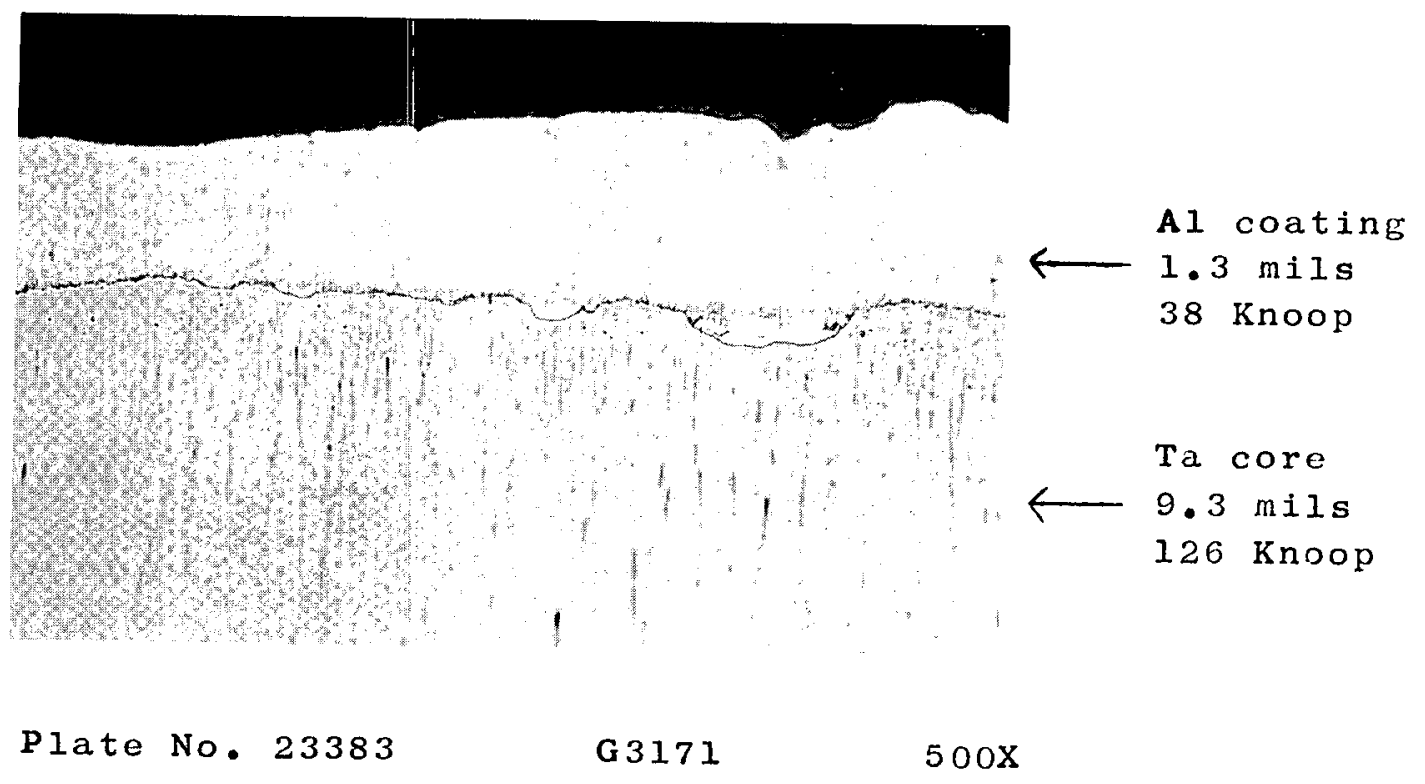

Fig. 5. Aluminum coated tantalum sheet as dipped 1 minute at $1700^{\circ} \mathrm{F}$. 


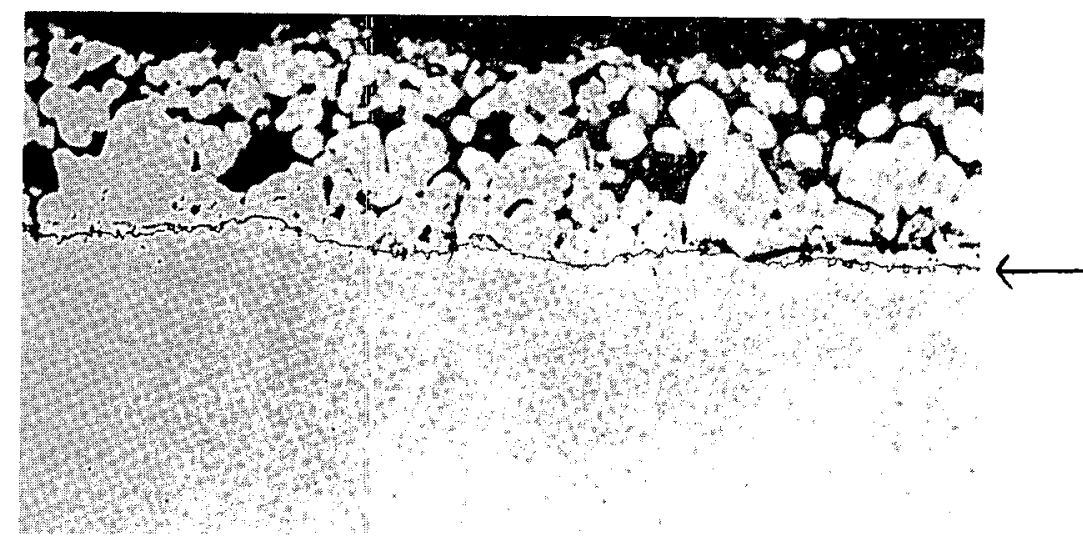

Al coating

$1.7 \mathrm{mils}$

$535 \mathrm{Knoop}$

717 Knoop

Ta $\operatorname{core}$

$8.4 \mathrm{mils}$

\section{Plate No. 23401. \\ G3171VD191 \\ $500 x$}

Vacuum diffused $1900^{\circ} \mathrm{F} \quad 1$ hour

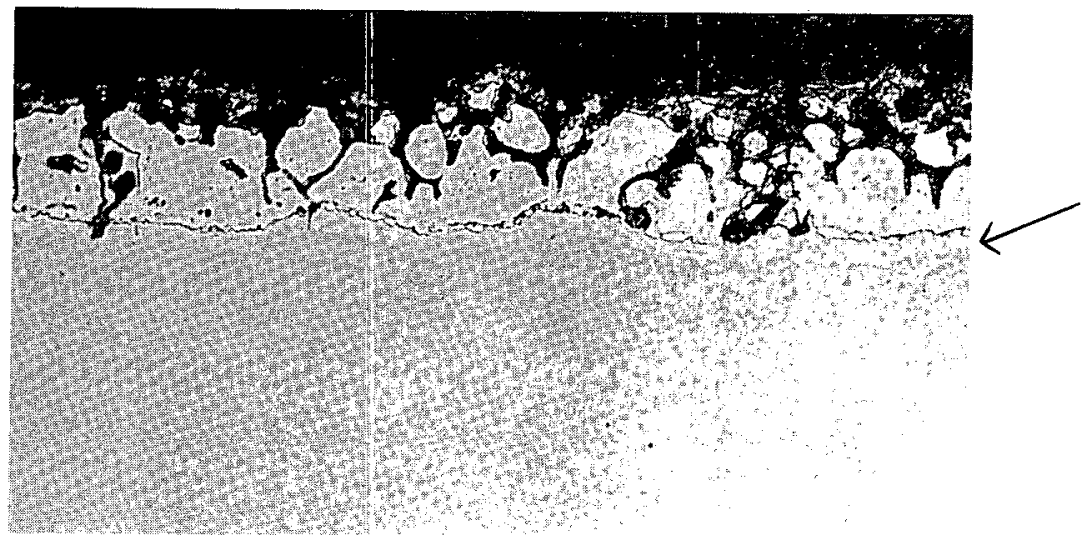

Al coating $1.2 \mathrm{mils}$ $480 \mathrm{Knoop}$

Ta core

$8.3 \mathrm{mils}$

Plate No. 23382

G317IVD194

$500 x$

Vacuum diffused $1900^{\circ} \mathrm{F} 4$ hours

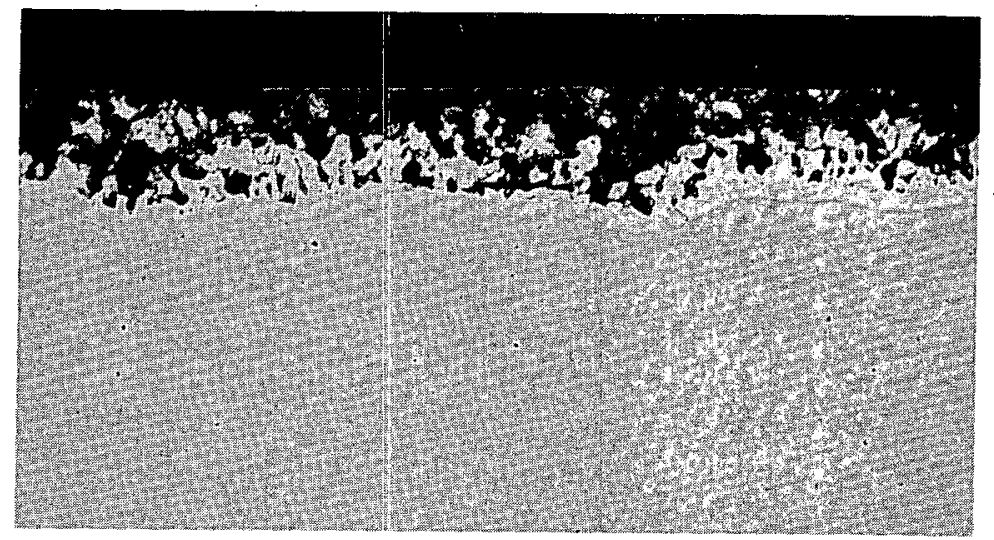

Al coating $1 \mathrm{mil}$

$719 \mathrm{Knoop}$

Ta core

8. 2 mils

$114 \mathrm{Knoop}$

Plate No. 23384

G 317 IVD 224

$500 x$

Vacuum diffused $2200^{\circ} \mathrm{F} 4$ hours

Fig. 6. Aluminum coated tantalum sheet dipped for 1 minute at $1700^{\circ} \mathrm{F}$, vacuum diffused. 


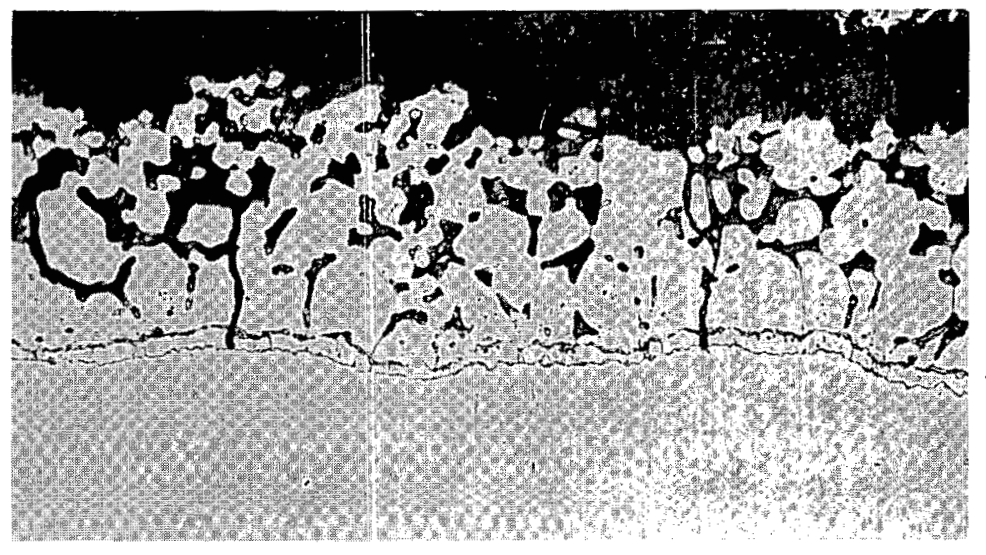

\section{Al coating \\ $1.9 \mathrm{mils}$ \\ 465 Knoop \\ 678 Knoop \\ Ta core \\ $8.1 \mathrm{mils}$ \\ $118 \mathrm{Knoop}$}
Plate No. 23397
G $3171 \mathrm{PC} 191$
$500 x$
Pack calorized $1900^{\circ} \mathrm{F} 1$ hour

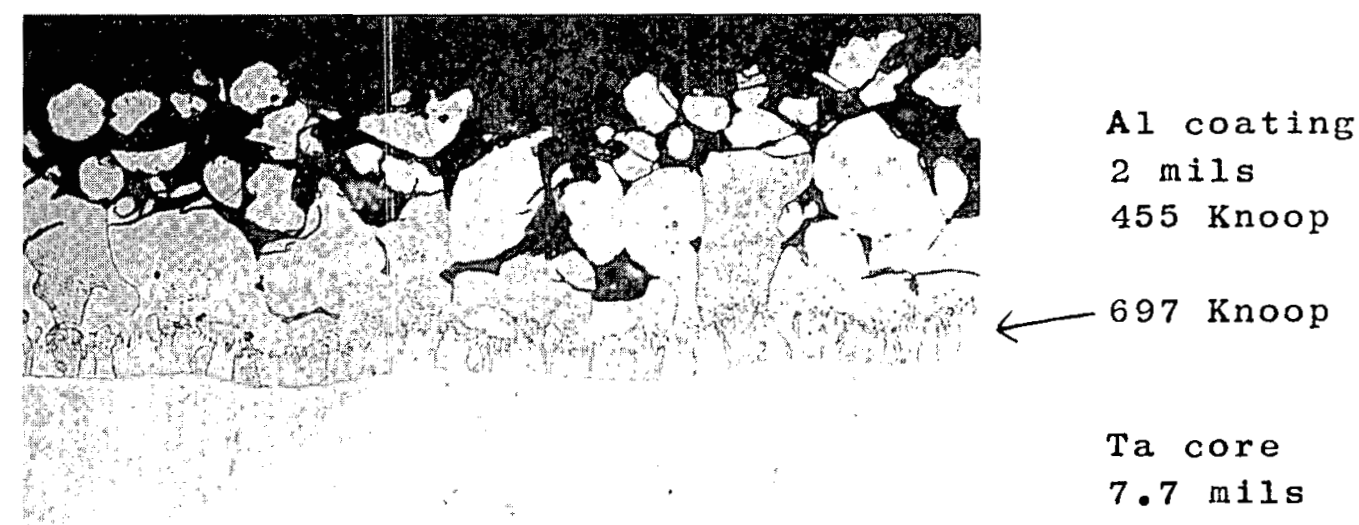
Plate No. 23381 G3171PC194 500X
Pack calorized $1900^{\circ} \mathrm{F} 4$ hours

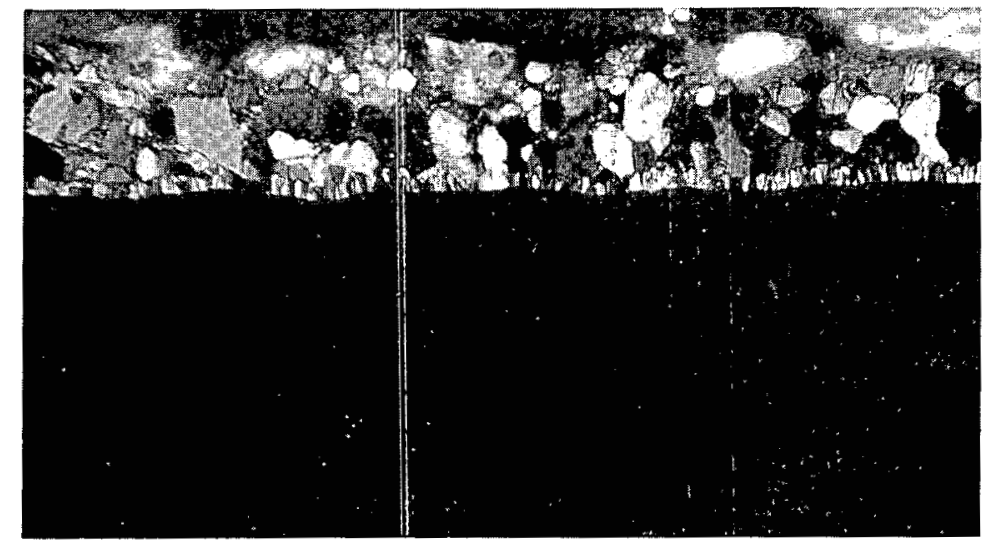
Plate No. 23387
G $31.71 \mathrm{PC} 194$
$500 x$
Pack calorized $1900^{\circ} \mathrm{F} 4$ hours polarized light

Fig. 7. Aluminum coated tantalum sheet dipped

I minute at $1700^{\circ} \mathrm{F}$, pack calorized 


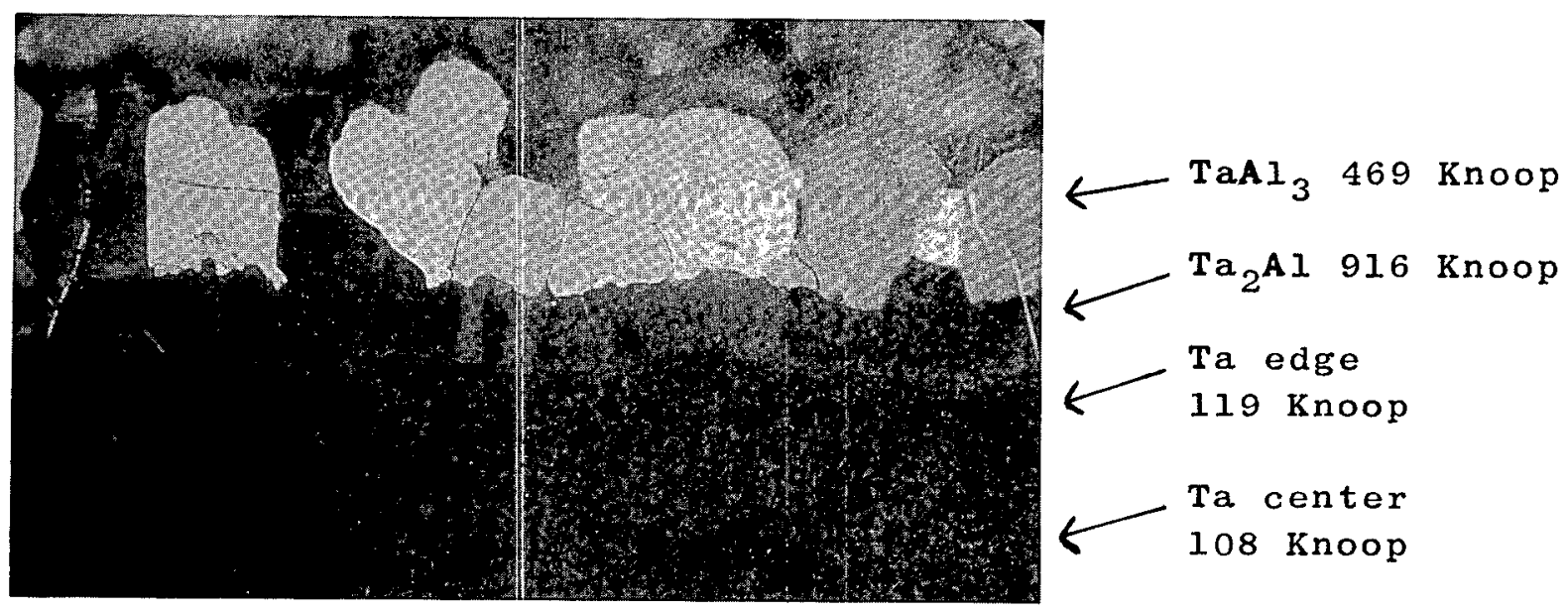

Plate No. 23677

$500 x$

Sample G3171PC221

Pack calorized $2200^{\circ} \mathrm{F} 1$ hour, polarized light.
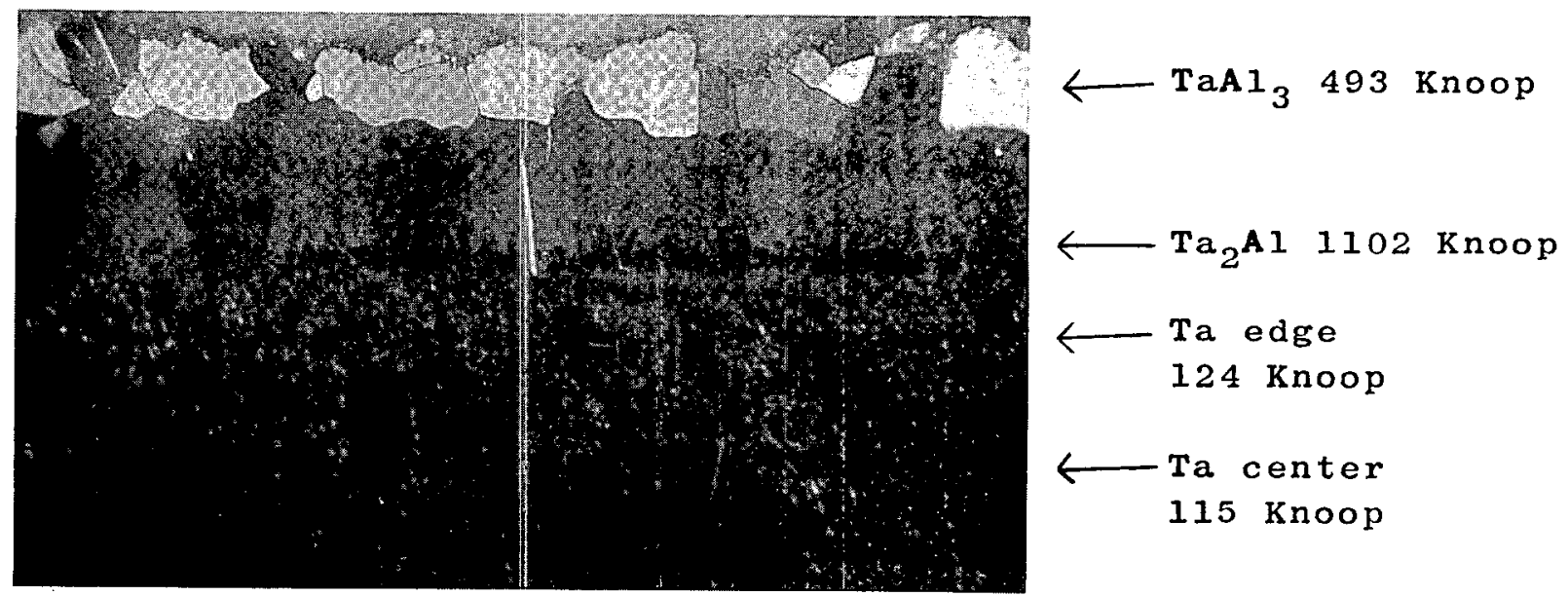

Plate No. 23676

$500 x$

Sample G3171PC224

Pack calorized $2200^{\circ} \mathrm{F} 4$ hours, polarized light.

Fig. 8. Aluminum coated tantalum sheet dipped for 1 minute at $1700^{\circ} \mathrm{F}$, pack calorized. 
TABLE 2

COATING COMPOSITIONS

Code

Identi-

fication

G 3

G 4

G5

G6

G 7

G 8

G9

G 10

G 11

G 12

G 13

G 14

G 15

G 16

G 17

G 18

G 19

G 20

G 21

$\mathrm{G} 22$

G 23

G 24

G 25

G 26

G 27

G 28

G 29

G 30

G 31

G 32

G 33

G 34

G 35

G 36

G 37

G 38

G 39

\section{Composition, \%}

Pure aluminum

A I-11 Si

A 1-10 Si-10 Cr

Al-25 Si

84.5 Al 10.5 Si $5 \mathrm{Y}$

$71 \mathrm{Al} 15 \mathrm{Cr} 9 \mathrm{Si} 5 \mathrm{sn}$

$90 \mathrm{Sn} 10$ (A1-10 $\mathrm{Bi}$ )

$\begin{array}{llllllll}71 & \mathrm{~A} & 15 & \mathrm{Cr} & 9 & \mathrm{Si} & 5 & \mathrm{Y}\end{array}$

$66 \mathrm{AI} 15 \mathrm{Cr} 9 \mathrm{Si} 5 \mathrm{Y} 5 \mathrm{sn}$

$90 \mathrm{Cu} 10$ (A1-10 Si)

$72 \mathrm{Cu} 22 \mathrm{Sb} 6 \quad(\mathrm{Al}-10 \mathrm{Si})$

$90 \mathrm{Al} 5 \mathrm{Cr} 5 \mathrm{Ti}$

95 AI $5 \mathrm{Cr}$

95 A. 5 Ti

95 (AI-10 Si) $5 \mathrm{Ti}$

90 (Al-10 Si) $5 \mathrm{Cr} 5 \mathrm{Ti}$

$80 \mathrm{Al} 13 \mathrm{Cr} 4 \mathrm{Sn} 3 \mathrm{Ti}$

$58.4 \mathrm{Cu} 34.4 \mathrm{Sb} 7.2(90 \mathrm{Al}-5 \mathrm{Ti}-5 \mathrm{Cr})$

$90 \mathrm{Sn} 10 \mathrm{Al}$

90 Al 5 Cr $5 \quad \mathrm{TiH}_{2}$

$85 \mathrm{Al} 10 \mathrm{Ti} \mathrm{H}_{2} 5 \mathrm{Cr}$

83 Al 10 Ti $H_{2} 5$ Cr 2 Ta

$30 \mathrm{AI} 10 \mathrm{TI} \mathrm{H}_{2} 5 \mathrm{Cr} 5 \mathrm{Sn}$

$90 \mathrm{Sn} 10\left(90 \mathrm{Al}-5 \mathrm{Ti} \mathrm{H}_{2} 5 \mathrm{Cr}\right)$

85 A $110 \mathrm{Cr} 5 \mathrm{Ti} \mathrm{H}_{2}$

85 AI 5 Cr 5 Ti $\mathrm{H}_{2} 5 \mathrm{Sn}$

89 Al $5 \mathrm{Sn} 3 \mathrm{Ti} \mathrm{H}_{2} 3 \mathrm{Cr}$

$85 \mathrm{Al} 5 \mathrm{Sn} 5 \mathrm{Cr} 5 \mathrm{Ti}$

85 Al 5 Sn 5 Cr 5 Ti $H_{2}$

94 AI 3 Ti $3 \mathrm{Cr}$

85 Al 5 Ti 5 Cr 5 Y

$50 \mathrm{AI} 50 \mathrm{Sn}$

$10 \mathrm{Al} 90 \mathrm{sn}$

$50\left(90 \mathrm{Al}-5 \mathrm{TiH}_{2}-5 \mathrm{Cr}\right) 50 \mathrm{Sn}$

35 Al 5 TI 5 Cr 5 La

$80\left(90 \mathrm{Al}-5 \quad \mathrm{TiH}_{2}-5 \mathrm{Cr}\right) 20 \quad \mathrm{Al}_{2} \mathrm{O}_{3}$

$\begin{array}{llllll}40 & \mathrm{Al} & 58 & \mathrm{Al}_{2} \mathrm{O}_{3} & 2 & \mathrm{NH}_{4} \mathrm{Cl}\end{array}$
Method of

Application

Molten Dip

Molten Dip

Molten Dip

Molten Dip

Molten Dip

Molten Dip

Molten Dip

Molten Dip

Molten Dip

Molten Dip

Molten Dip

Molten Dip

Molten Dip

Molten Dip

Molten Dip

Molten Dip

Molten Dip

Molten Dip

Molten Dip

Paint

Paint

Paint

Paint

Paint

Paint

Paint

Paint

Molten Dip

Paint

Molten Dip

Molten Dip

Paint or spray

Paint

Paint or spray

Molten Dip

Vacuum Pack Calorized

Argon Pack Calorized 
TABLE 2 (Cont* $\left.\mathrm{d}_{0}\right)$

COATING COMPOSITIONS

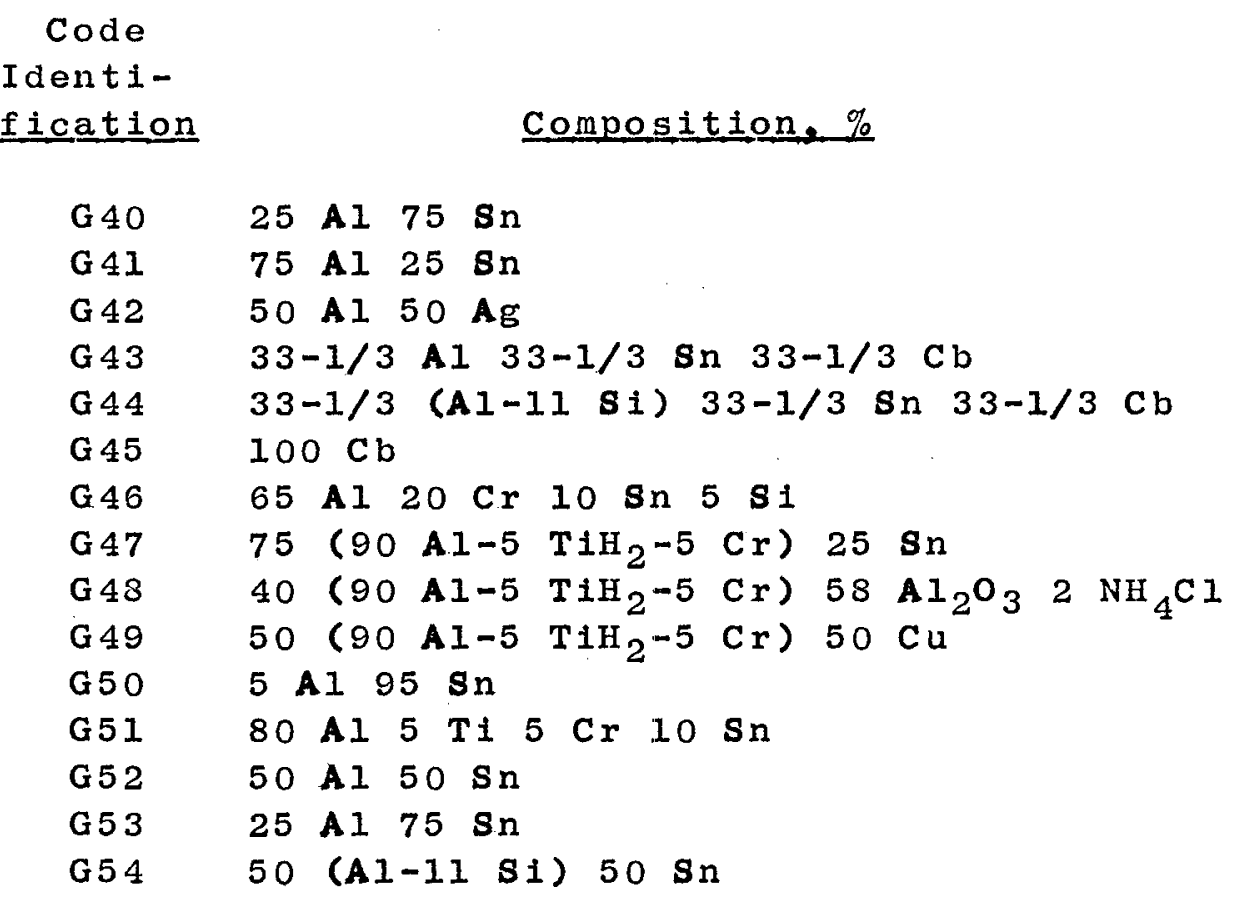

Method of Application

Paint or Spray Paint or Spray Paint Paint Paint Spray Paint Paint or Spray Argon Pack Spray Molten Dip Molten Dip Molten Dip Molten Dip Paint 
Cr composition (G14) applied by hot dipping at $1900^{\circ} \mathrm{F}$ for 30 seconds followed by an argon diffusion treatment of 1 hour at $1900^{\circ} \mathrm{F}$ in a powder mixture of $10 \mathrm{Al}$ and $90 \mathrm{Al}_{2} \mathrm{O}_{3}$ 。 But, as with all other tin-free aluminum compositions investigated in this program, the G14 coating has poor low temperature oxidation resistance in the range from $1100^{\circ}$ to $1800^{\circ} \mathrm{F}$ and has poor thermal cycling oxidation resistance between test temperature $\left(2500^{\circ}\right.$ to $\left.2800^{\circ} \mathrm{F}\right)$ and ambient.

\section{A. Compound Studies}

Therefore, it was decided to obtain base line data on the oxidation characteristics of various compositions in the Ta-Al system. Arc-melted samples of $\mathrm{TaAl}_{3}$, "TaAl", $\mathrm{Ta}_{2} \mathrm{~A} \mathbf{I}, \mathrm{Ta}_{3} \mathrm{~A} \mathrm{I}_{\text {, }}$ and $\mathrm{Ta}_{0.9}$

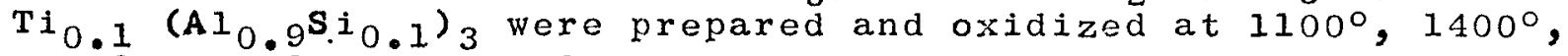
$1800^{\circ}, 2300^{\circ}$, and $2500^{\circ} \mathrm{F}$.

The following conclusions can be made:

1. The oxidation results vary with location of coupon taken from the arc-melted sample.

2. None of these materials is single-phase as melted, probably caused by aluminum loss during arc-melting. It is known that there is no intermetallic compound of the conposition $\operatorname{TaA}(4)$ 。

3. $\mathrm{Ta}_{2} \mathrm{Al}$ and $\mathrm{Ta}_{3} \mathrm{Al}$ are not oxidation resistant at any temperature tested。

4. TaAl 3 and the particular alloyed compound tested are not oxidation resistant at $1400^{\circ} \mathrm{F}$ but do have satisfactory potential at $2500^{\circ} \mathrm{F}$.

This information helps to explain the low temperature anomaly and gives an indication of what to expect with tantalum aluminide type coatings. The $1400^{\circ} \mathrm{F}$ rapid oxidation was expected from later work on the columbium-aluminum system. But it was also assumed that tantalum trialuminide $\left(\mathrm{TaAl}_{3}\right)$ would be more stable than columbium trialuminide $\left(\mathrm{CbAl}_{3}\right) \cdot \mathrm{CbAl}_{3}$ was still present after 10 hours of air oxidation at $2600^{\circ} \mathrm{F}$ with aluminum coated columbium materials. The same was not true with aluminum coated tantalum materials. In fact times of less than one hour at temperatures as low as $2000^{\circ} \mathrm{F}$ in any atmosphere, under certain conditions, are enough to convert the $\mathrm{TaAl}_{3}$ coating phase on tantalum to $\mathrm{Ta}_{2} \mathrm{Al}$ and $\mathrm{Ta}_{3} \mathrm{Al}$. The effect 
is shown in Figures 7 and 3 comparing a s-hour difiusion heat treatment at $1900^{\circ}$ and $2200^{\circ} \mathrm{F}$. At the lower temperature the coating consists of almost entirely $\mathrm{TaAl}_{3}$ but at $2200^{\circ} \mathrm{F}$ little is left.

The TaAl 3 phase must be present to form an oxidation resistant coating. This phase is reduced by the oxygen in the air at test temperature to form the protective $\mathrm{Al}_{2} \mathrm{O}_{3}$ outer layer and $\mathrm{Ta} \mathrm{A}^{\mathrm{A} I}$ and Ta ${ }_{3} \mathrm{Al}$. Without going into detail at this point of the discussion the foregoing should give an idea of the problems to be met and solved to produce aluminum type coatings on tantalum that will protect it for at least 10 hours with a minimum of 10 thermal cycles under mechanical stress at test temperatures up to $2800^{\circ} \mathrm{F}$.

\section{B. Oxidation Results}

Since hundreds of oxidation tests have been run the individual results of such tests would fill dozens of tables and might prove tedious for the reader to cover. It appears preferable to give a concise appraisal and comparison of the general trends in oxidation behavior for the numerous combinations of coatings listed in Table 2 。

Hot dipping in small aluminum alloy baths was used initially for screening purposes because of the ease of changing compositions, temperature, and time of coating. Later other application techniques were used. Post coating diffusion heat treatments were also investigated.

It was found that a $1700^{\circ} \mathrm{F}$ dipping temperature was too low to give the required oxidation protection at $2500^{\circ} \mathrm{F}$ to tantalum when dipped into (a) pure aluminum (G3), (b) Al-1ISi (G4), (c) Al-ll Si$5 \mathrm{Y}$ (G7), or (d) Al-25 Si (G6). Tantalum samples dipped into pure aluminum (G3) at $2100^{\circ} \mathrm{F}$ without a diffusion heat treatment would withstand 4 hours at $2500^{\circ} \mathrm{F}$ isothermally。 Failure occurred at longer times. Al-1I Si-5 Y coated samples (G7) dipped at $2000^{\circ} \mathrm{F}$ for 1 minute followed by a pack calorizing diffusion heat treatment of 1 hour at $1900^{\circ} \mathrm{F}$ increased oxidation protection to at least 8 hours at $2500^{\circ} \mathrm{F}$ but failure always occurred after 1 cycle to room temperature and reheating to $2500^{\circ} \mathrm{F}$. The addition of $25 \mathrm{si}$ to the aluminum bath (G6) resulted in a non-adherent scale when oxidized at 2500 $\mathrm{F}$. The Al-10 Si-10 Cr composition (G5) gave little added improvement in oxidation protection. The AI-15 Cr-9 Si-5 Sn composition (Go) would give 10 hours protection at $2500^{\circ}$ and $2600^{\circ} \mathrm{F}$ with a few thermal cycleso All of these coating compositions would fail in a few hours if oxidized at $1100^{\circ}$, $1400^{\circ}$, or $1800^{\circ} \mathrm{F}$. 
The mechanism for this anomalous behavior is not known. However, it is postulated that the major factor is an expansion mismatch between the original $\mathrm{TaAl}_{3}$ intermetallic and the alloy substrate, the former having the higher coefficient, on cooling from the formation temperature to ambient temperatures the brittle surface compound is put in tension and cracks。 Upon reheating to temperatures below the formation temperature the cracks do not close up and the substrate with its poor oxidation resistance is severely attacked. If the material is heated above its formation temperature the cracks close up and the surface is put in compression. There is also the possibility that diffusion of aluminum is not rapid enough at lower temperatures for the protective oxide film to repair itself or that a nonprotective porous film is formed at lower temperatures.

The beneficial effect of $t$ in additions to aluminum alloy compositions as applied to tantalum was first shown with the Al-15 Cr9 Si-5 Sn composition (G8)。 Yttrium was added to this composition with and without tin ( $G 10$ and $G 11$ ) but no improvement in oxidation behavior was obtained. The $90 \mathrm{sn}-10$ (Al-11 $\mathbf{S i}$ ) composition (G9) caused a major breakthrough in oxidation protection. It will be discussed in a later section. substituting copper or copper and antimony (GI2 and G13) for $t$ in as the diluent did not show too much promise.

The Gl4 composition, 90 Al-5 Ti-5 Cr, was the best tin free aluminum alloy found for protecting tantalum and the Ta-10 W alloy in the temperature range of $2500^{\circ}$ to $2800^{\circ} \mathrm{F}$. Over 150 samples of tantalum materials were oxidation tested in a furnace or by resistance heating. Samples electrically heated could take 10 hours and 10 cycles at $2500^{\circ}, 2600^{\circ}$, and $2700^{\circ} \mathrm{F}$ under a stress to produce from 2 to $14 \%$ elongation without oxidation failure. Samples could also withstand 10 hours at $2800^{\circ} \mathrm{F}$ but cycling greatly reduced its Iife. Although furnace tested samples would last 10 hours at $2500^{\circ}$ and $2600^{\circ} \mathrm{F}$ with cycles, behavior was more erratic. This was probably caused by sintering of the $\mathrm{Al}_{2} \mathrm{O}_{3}$ in the coating to the recrystallized alumina boats with resultant rupturing of this oxide coating when handled for inspection. The time and temperature of use was increased by supporting the samples with platinum wires. In fact one sample lasted 308 hours at $2500^{\circ} \mathrm{F}$ 1sothermally without fallure. This also points up the increased life without thermal cycling. This same coating applied by painting on the metal powders followed by a vacuum diffusion heat treatment (G22) had similar oxidation properties. Coating thickness was 1.5 mils. 
Effort was spent in varying the basic composition of G14 to try to improve properties. The addition of $5 \%$ tin seemed to increase the strength by reducing the alloy core loss in thickness as a function of time and temperature. In general, no improvement was found in any other composition change from 90 Al-5 Ti-5 Cr. This statement rules out coating composition and/or method of application G15, 16, 17, 18, 19, 20, 23, 24, 25, 27, 28, 29, 30, 31, 32, 33,37 , and 51. In any case the G14 composition also suffers from reduced low temperature oxidation resistance. This is not meant to rule out any aluminide composition as having poor high temperature oxidation behavior because Gl4 does have very good properties. But once again it must be reaffirmed that the Sn-Al coatings are much easier to apply and use for practical applications without any peculiar anomalies, at least on certain tantalum alloys。

Three coatings were applied by pack calorizing techniques. The samples were heated in a powder mixture for four hours at $1900^{\circ} \mathrm{F}$ (G38, 39, and 48). Samples would last for 16 hours at $2500^{\circ}$ and $2600^{\circ} \mathrm{F}$ without iailure but one thermal cycle was enough to cause failure. A second coating overlay of $\mathrm{Sn}-\mathrm{Al}$ improves cyclic behavior but not enough to warrant additional work at this time.

Because of the rapid dissolution of $\mathrm{TaAl}_{3}$ and the known stability of $\mathrm{CbAl}_{3}$, attempts were made to apply $\mathrm{Cb}-\mathrm{Al}-\mathrm{Sn}$ coatings directly to tantalum ( $\mathrm{G} 43$ and $\mathrm{G} 44$ ) or to put a $\mathrm{Cb}$ layer on the $\mathrm{Ta}$ (G45) and coat. The first technique did not work and the second idea might work with more effort. This would involve finding more successful coatings for columbium which is not believed to be as practical as coating tantalum at this time.

\section{Metallographic Results on Al Coatings}

Metallography has been a valuable tool in the present coating work. Microstructures together with Knoop hardness values (25 gram load) graphically show movements of compound interiaces, solution of tantalum, oxide growth, and serve to identify intermetallic compounds. The effect of oxidizing time and temperature on Gl4 coated pure tantalum are shown in Figure 9. After only one hour of oxidation at $2500^{\circ} \mathrm{F}$, the $\mathrm{TaAl}_{3}$ has disappeared. Hereafter, the major portion is $\mathrm{Ta}_{2} \mathrm{~A} 1$ which contains considerable porosity with the $\mathrm{Ta}_{3} \mathrm{Al}$ thickness increasing with time. The dense $\mathrm{Al}_{2} \mathrm{O}_{3}$ film can be seen and it can be noted that the oxide layer is thin and grows very slowly. The sintering of the porous $\mathrm{Ta}_{2} \mathrm{Al}$ at higher temperatures and longer times is also noteworthy. Although tantalum is being dissolved, the rate is relatively slow. Oxidation times of 


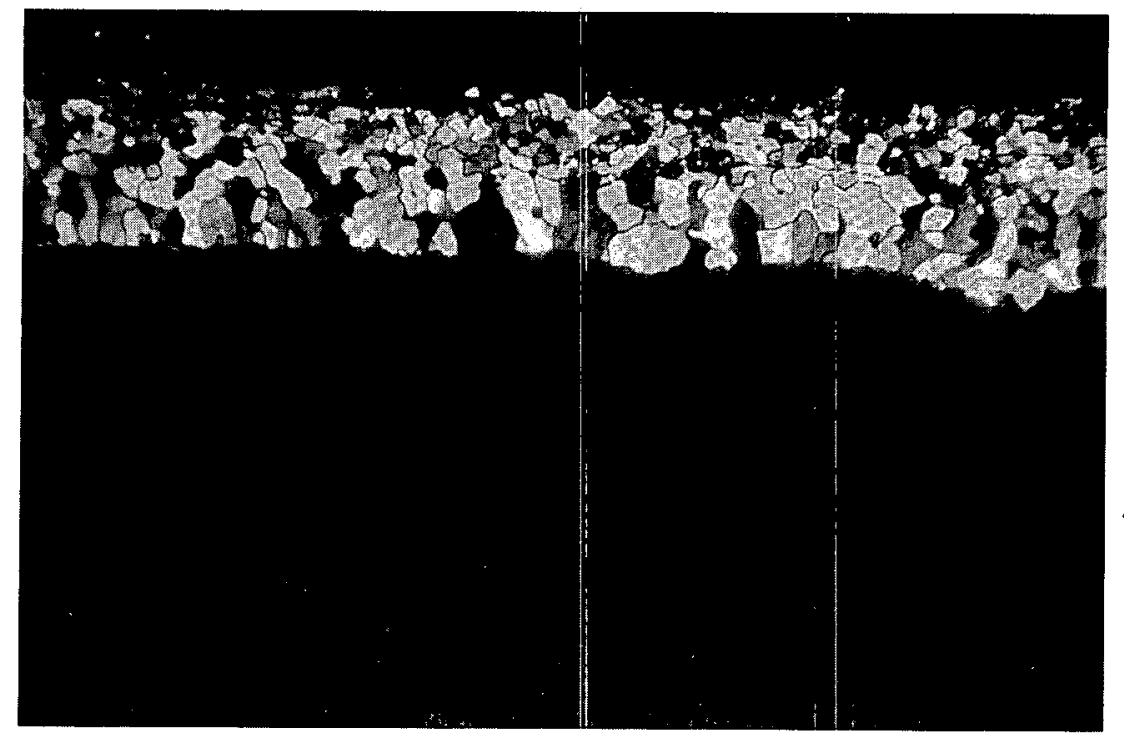

Knoop

Mils

$\leftarrow \operatorname{TaAl}_{3}$

559

3.2

$\longleftarrow$ Ta $\begin{gathered}\text { Edge } \\ \text { Center }\end{gathered}$

130

TOTAL

129

9.9

16.1

Plate No. 23667 Sample G14B19-1/2PC191 $250 \mathrm{X}$

Polarized light diffused 1 hour $1900^{\circ} \mathrm{F}$

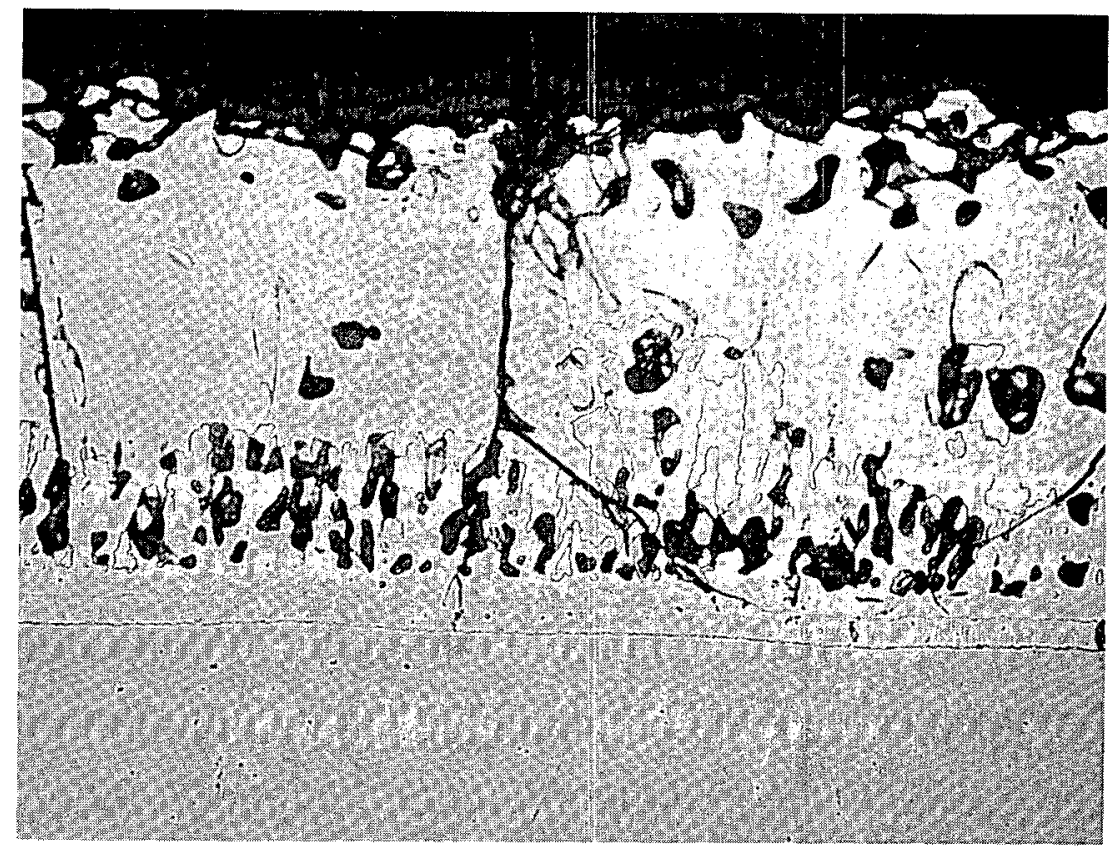

$\leftarrow_{2} \mathrm{Ta}_{1}$

1120

$4 \cdot 2$

$\leftarrow \mathrm{Ta}_{3} \mathrm{AI}$

1160

$\leftarrow^{\text {Tadge }}$ Center

141

TOTAL

6.9

16.0

Plate No. 23680 Sample G14B19-1/2PC191-44500X

Bright field oxidized 1 hour $2500^{\circ} \mathrm{F}$

Fig. 9a. Effect of oxidation time and temperature on $90 \mathrm{Al}-5 \mathrm{Ti}-5 \mathrm{Cr}$ coated tantalum. 


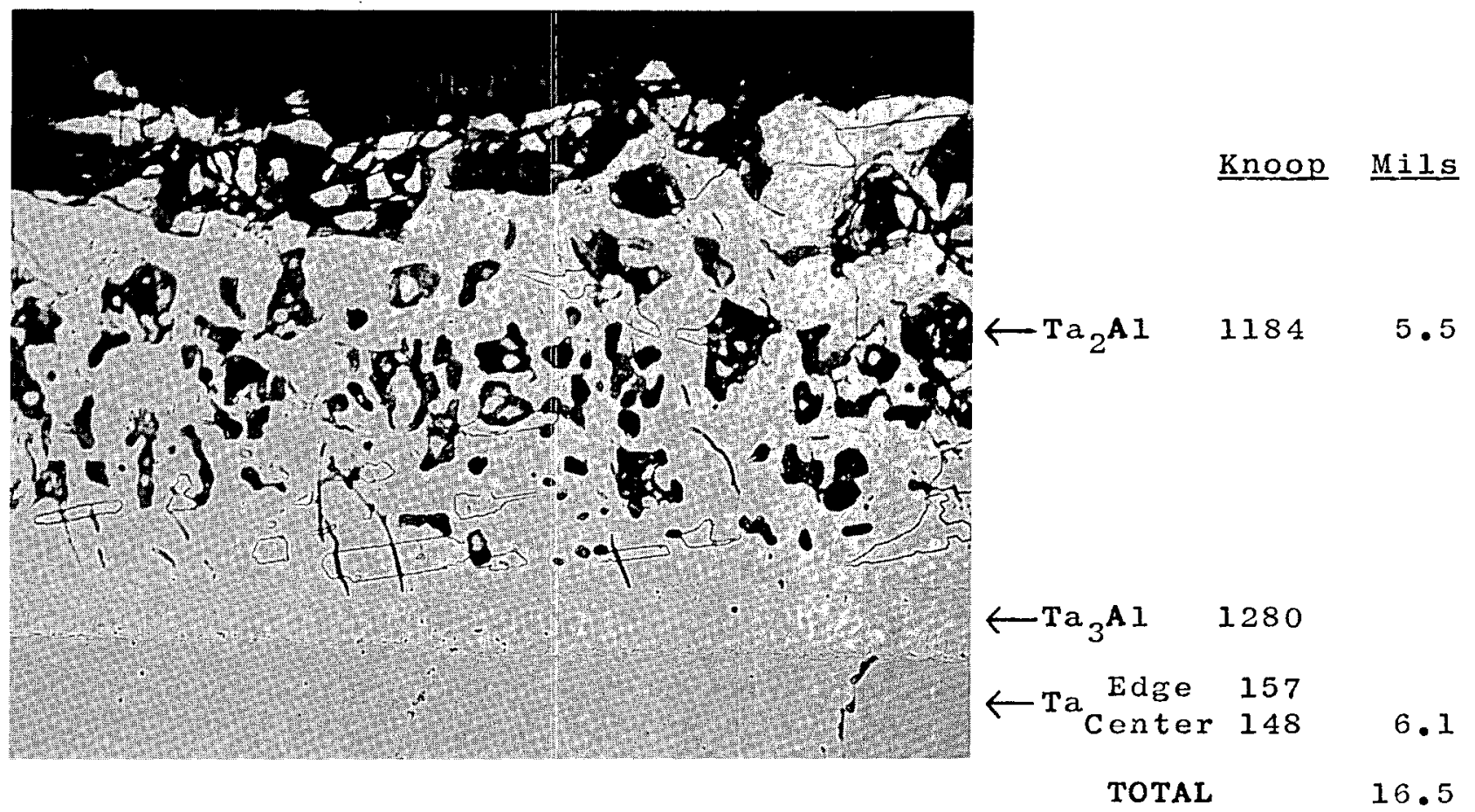

Plate No. 23679

$500 x$

Sample G14B19-1/2PC191-52

Fig. 9b. Oxidized 10 hours at $2500^{\circ} \mathrm{F}$. 


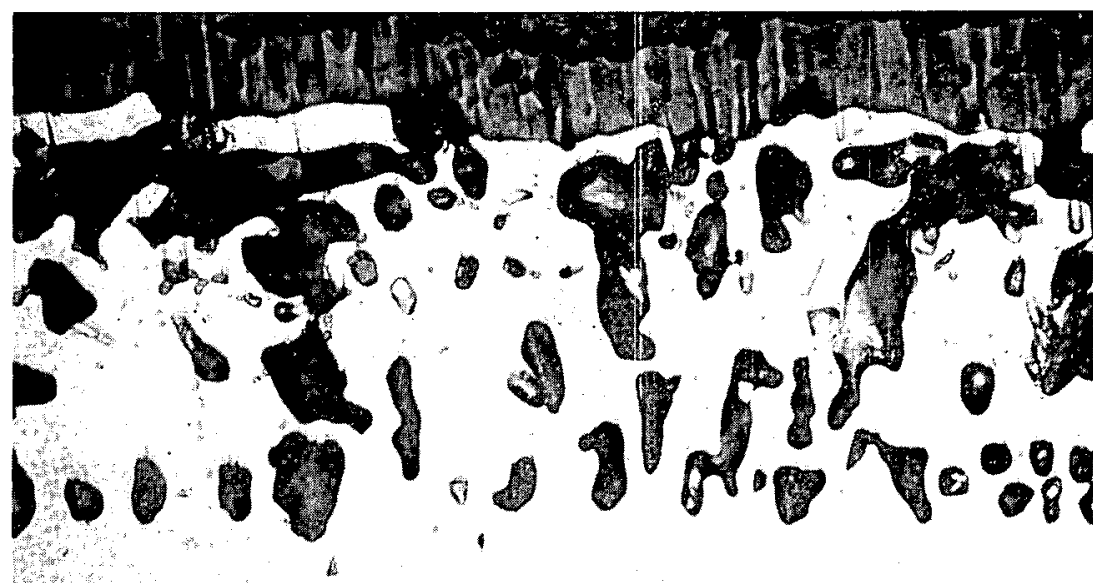

Knoop Mils

$\leftarrow \mathrm{Al}_{2} \mathrm{O}_{3} \quad 4630$

$\longleftarrow \mathrm{Ta}_{2} \mathrm{Al} \quad 1648$

$5 \cdot 8$

$$
\longleftarrow \operatorname{Ta}_{3} \mathrm{Al} \quad 1352
$$

$\frac{1}{4}$

and

Plate No. 23666

Sample G14B19-1/2PC191-51

Fig. 9c. Oxidized 96 hours at $2500^{\circ} \mathrm{F}$.

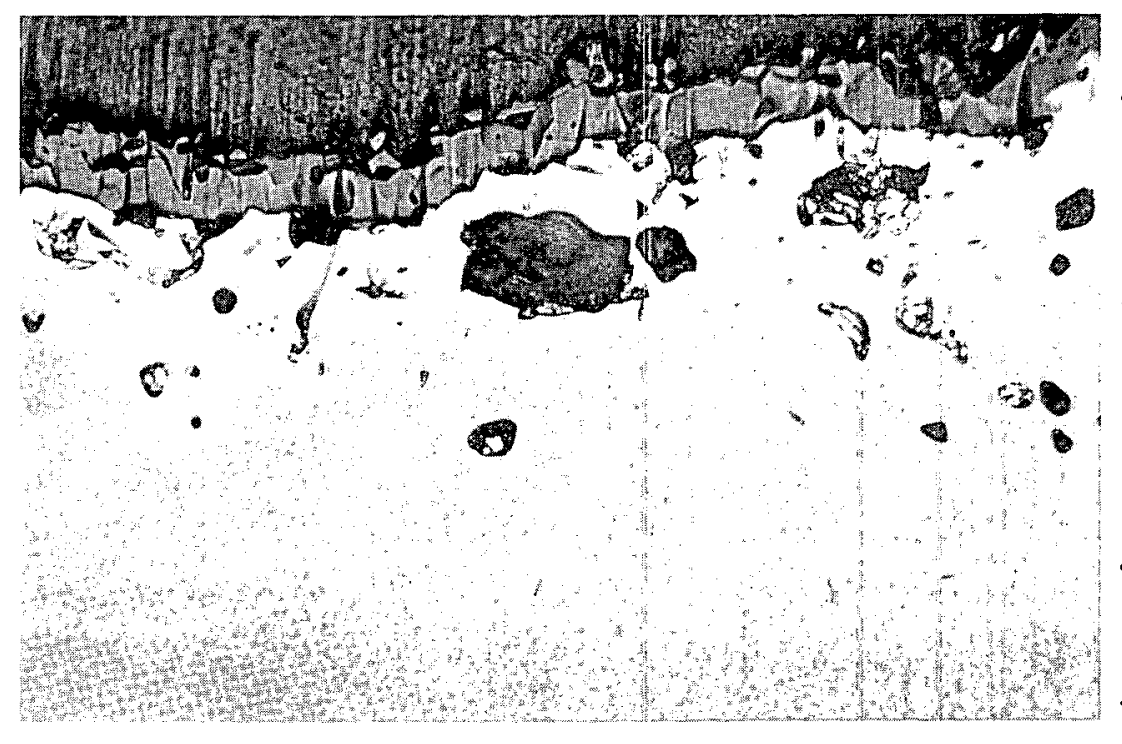

Plate No. 23709

Sample G14A19-1/2PC191-29 $\leftarrow \mathrm{Al}_{2} \mathrm{O}_{3}$

0.46
4.9

16.9

$500 x$

TOTAL

Fig. 9c. Oxidized 10 hours at $2700^{\circ} \mathrm{F}$. 
Knoop Mils

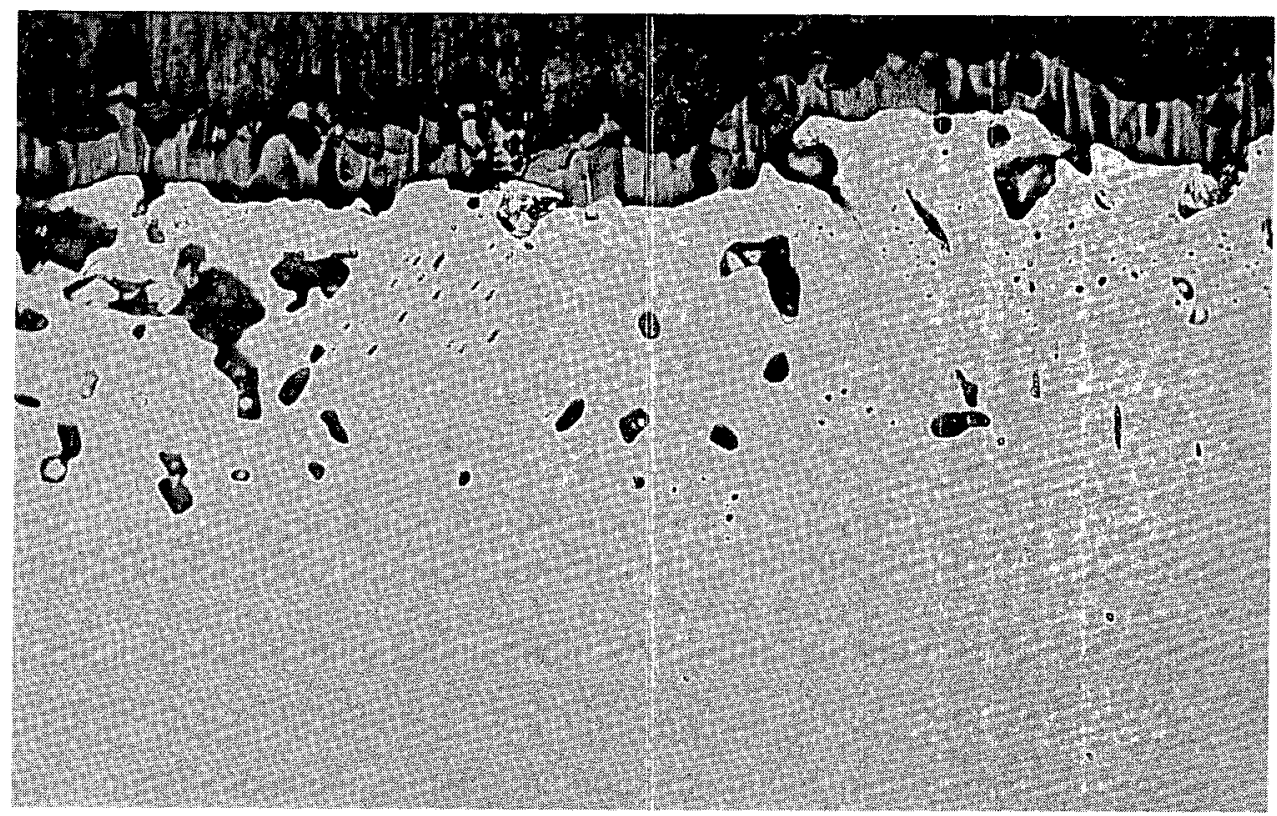

Plate No. 23707

Sample G14191PC191-20 $\leftarrow \mathrm{Al}_{2} \mathrm{O}_{3}$

$\leftarrow \mathrm{Ta}_{2} \mathrm{~A} 1 \quad 1106$

$\leftarrow \mathrm{Ta}_{3} \mathrm{Al} \quad 1142$

$\leftarrow$ Ta Edge 188

Center 153

TOTAL
0.49

$3 \cdot 7$

Fig. 9d. Oxidized 10 hours at $2800^{\circ} \mathrm{F}$. 
ten hours at $2800^{\circ} \mathrm{F}$ have only reacted with 2 to 2.5 mils per side. Microhardness tests indicate some internal hardening although it does not appear too serious. The maximum core hardness increases from 130 kHN for the as-received cold worked tantalum to 230 KIN arter oxidation. The effect of oxidation time at $2500^{\circ} \mathrm{F}$ on reaction rates and hardness is plotted in Figure 10. Metallographic examination revealed no evidence of internal second phase precipitation.

\section{TIN-ALUMINUM COATINGS}

\section{A. Dip Coating}

Coating thickness can usually be controlled by adjusting temperature and time but, with $1900^{\circ} \mathrm{F}$ or so, dipping temperature times are in seconds. To obtain better control of time, tin was added to the aluminum alloy compositions to act as a diluent and reduce the aluminum concentration. The first composition tried was 90 sn-10 (A1-11 Si) (G9). Dipping time was 10 minutes at $1900^{\circ} \mathrm{F}$ following by a 1 hour pack calorizing heat treatment at 1900\%. After this processing schedule the coating was 2 mils $\left(0.002^{\prime \prime}\right)$ thick per side, $1 \mathrm{mil}$ of $\mathrm{TaAl}_{3}$ and 1 mil of unreacted Sn-Al alloy, with only 0.5 mil core regression per side. Shorter dipping times gave a nonuniform coating thickness with variable oxidation results。 Longer dipping times at lower temperatures did not give any better results, in fact poorer. Figure 11. shows the microstructure of an oxidized sample.

Silicon additions to aluminum compositions did not improve oxidation behavior. Therefore, the $90 \mathrm{sn}-10$ Al (G21) composition was tried next. The effect of diffusion heat treatment is given in Figure 12. This coating on tantalum will withstand considerable abuse, in fact it shows some self-healing abilities. Tensile samples have been abraded into the tantalum core, Vickers hardness impressions put into the composites, twisted, bent $90^{\circ}$ over a $0.020^{\circ}$ die radius, in fact twisted into a knot and then electrically lieated to $2600^{\circ} \mathrm{F}$ for 10 hours with 10 cycles without oxidation failure. A picture of the knot sample after test is given in Figure 13.

Using tensile type direct resistance heated samples for oxidation testing, the following statements can be made about the $G 9$ and G21 compositions: 

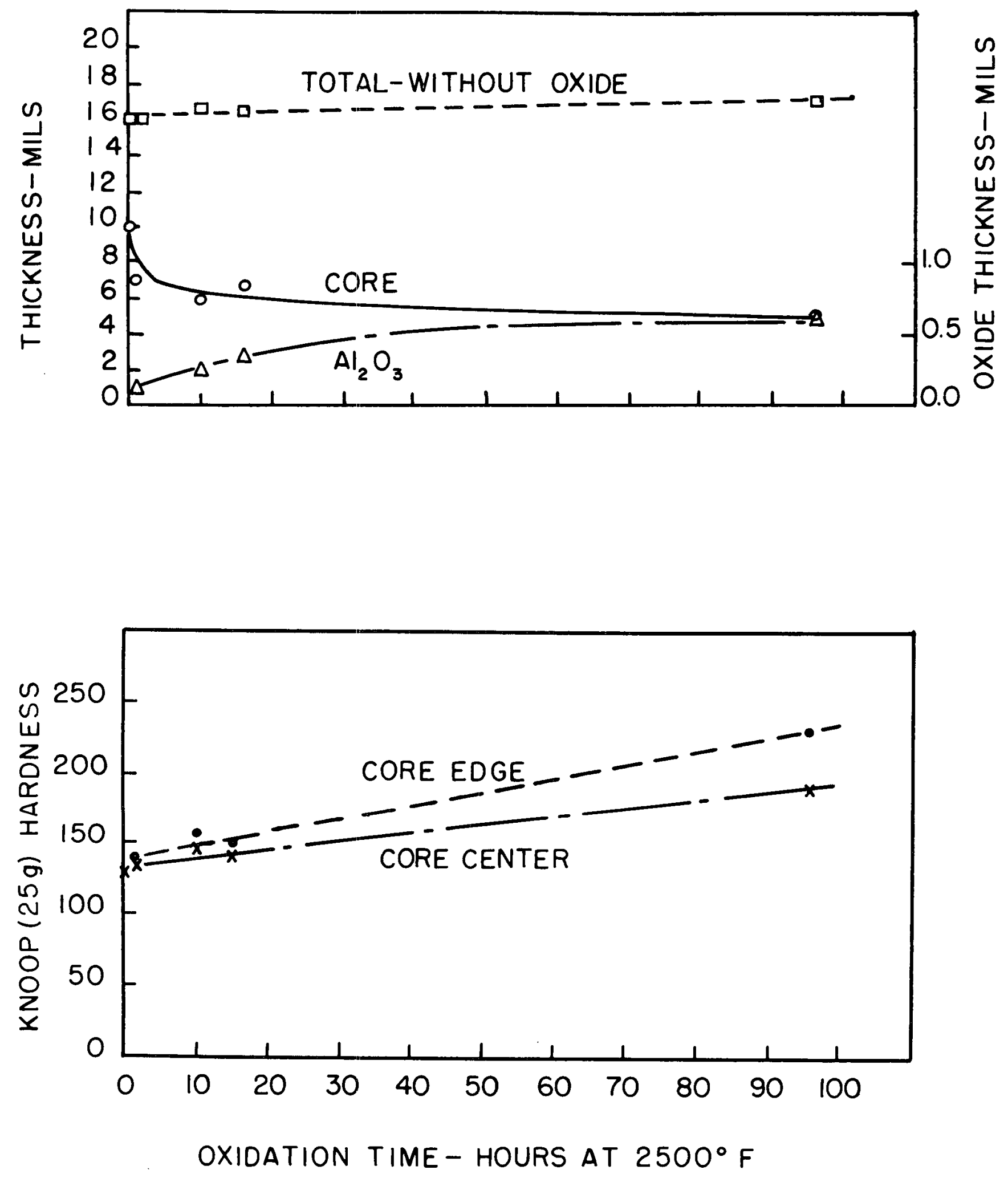

Fig. 10. Effect of time on core thickness and internal hardening of samples dip coated with Al-5 Cr5 Ti. 


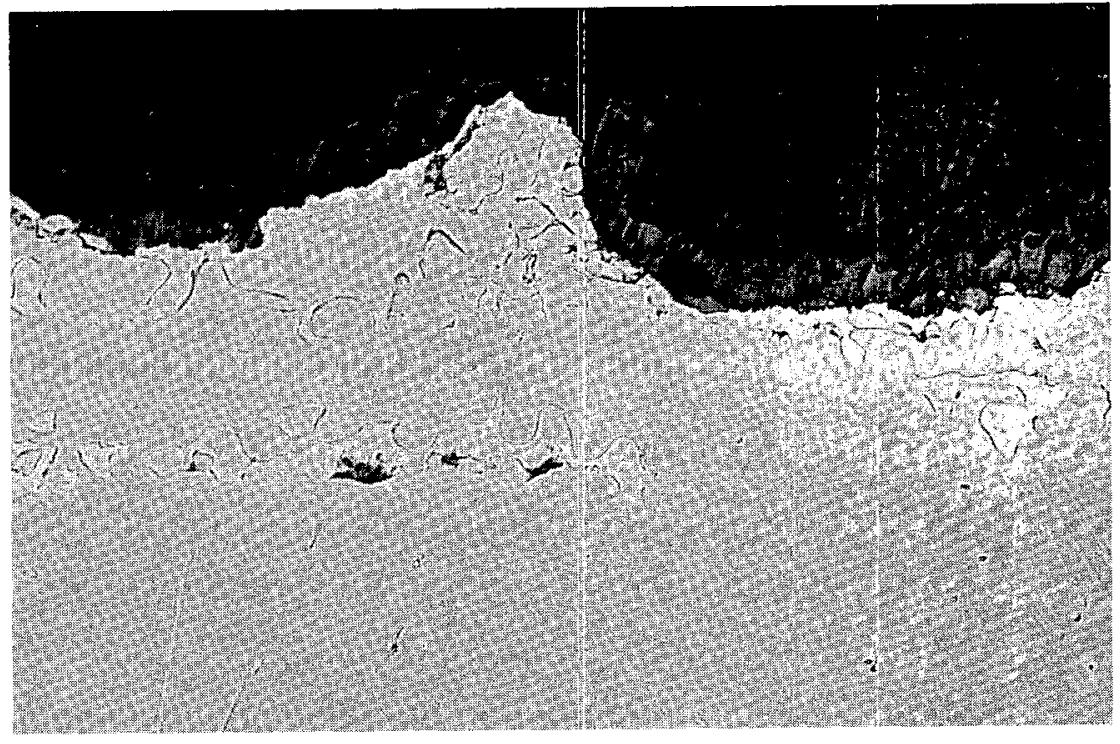

$\leftarrow$ coating

$\leftarrow$ Ta $\begin{array}{r}\text { Edge } \\ \text { Center }\end{array}$

TOTAL
Knoop

Mils

1101

1.2

Plate No. 23678

Sample G91910PC191-21

$$
\text { Bright field. }
$$

Fig. 11. 90\% tin-10\% (AI-10 Si) coated tantalum after oxidized 10 hours at $2600^{\circ} \mathrm{F}$. 


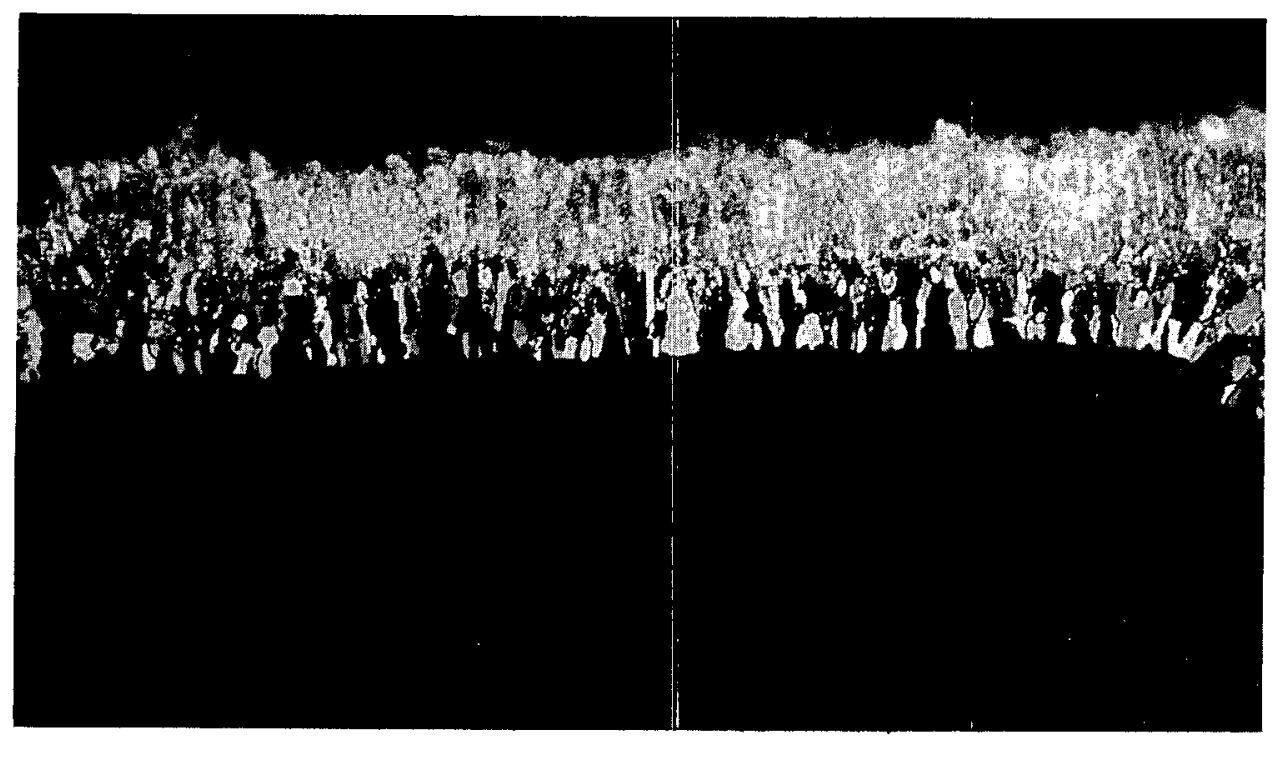

Knoop Mils

$\leftarrow$ Unreacted

$1 \cdot 2$

$\leftarrow \mathrm{TaAl}_{3}$

609

$\longleftarrow$ Tacenter

117

TOTAL

114

8.9

$15 \cdot 4$

Plate No. 23670

Sample G211910PC191

$500 x$

1 hour $1900^{\circ} \mathrm{F}$

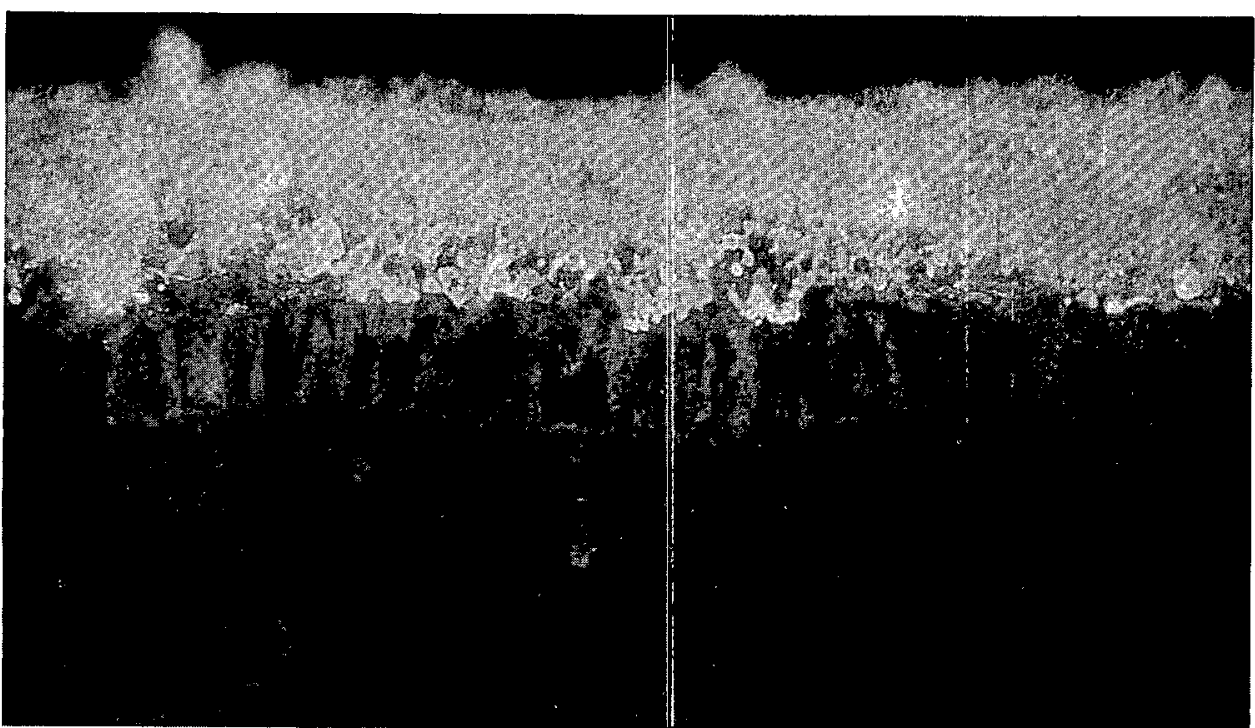

$\leftarrow$ Unreacted

$\leftarrow \operatorname{TaAl}_{3}$

$\kappa_{\text {TaAl }_{2}}$

1034

$\leftarrow \mathrm{Ta} \begin{gathered}\text { Edge } \\ \text { Center }\end{gathered}$

TOTAL

115

$1 \cdot 3$

$9 \cdot 7$

14.2

Plate No. 23671

Sample G211910PC221

$500 x$

1 hour $2200^{\circ} \mathrm{F}$

Fig. 12. Effect of diffusion temperature on $90 \%$ tin-10\% aluminum coated tantalum. 


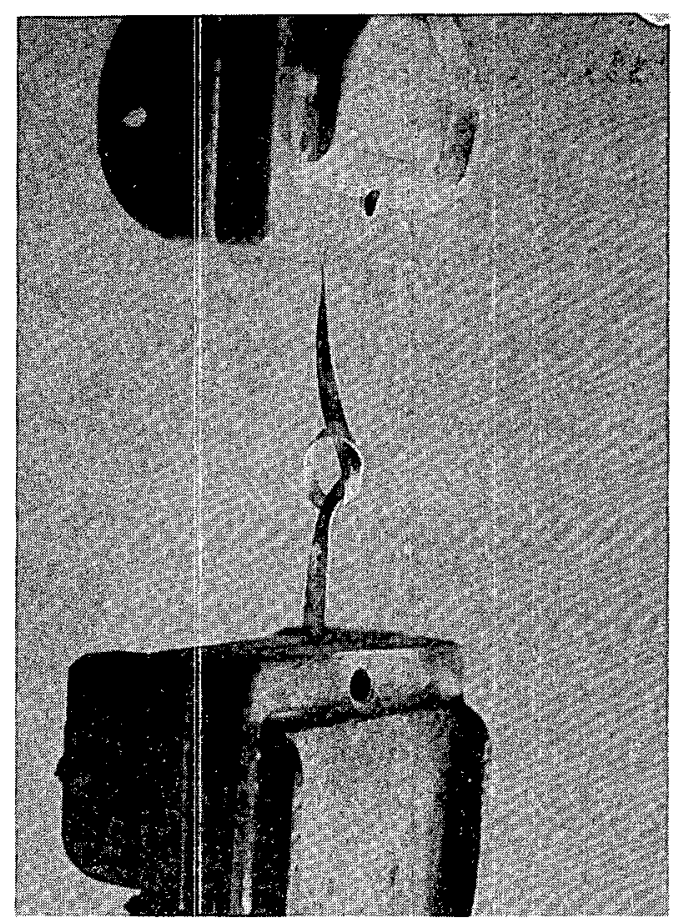

Fig. 13. $90 \% \mathrm{Sn}-10 \%$ Al coated tantalum twisted into a knot. 
1. Dipped and diffused samples will consistently withstand under stress ten hours and ten cycles (to sixty) to room temperature in an air blast at $2500^{\circ}$ and $2600^{\circ} \mathrm{F}$ without any oxidation failure。

2. Samples were heated to $2700^{\circ} \mathrm{F}$ for ten hours without failure but this and higher temperatures seem to be beyond their capabilities since these compositions will not withstand thermal cycling as well as other compositions.

3. As-dipped samples of G2l will readily withstand ten hours and ten cycles at $2500^{\circ}$ and $2600^{\circ} \mathrm{F}$ successfully. Diffusion treatment seems to be detrimental as compared to asdipped samples。

Notwithstanding these results, it is important to note that samples using G9 or G2l will not take furnace oxidation at $2500^{\circ} \mathrm{F}$ for ten hours with cycling to room temperature. G2l coated Ta-lo W alloy samples would consistently withstand 16 hours isothernally at $2500^{\circ}, 2600^{\circ}$, and $2700^{\circ} \mathrm{F}$ in a furnace. Most samples fail in 2 to 7 hours with hourly cycles to room temperature。 cyclic failure was probably caused by reaction of the coating with the ceramic boats. The effect of oxidation time at $2500^{\circ} \mathrm{F}$ on reaction rates and hardness is given in Figure 14。 The Ta-10 W alloy recrystallized during oxidation causing a softening effect. The decrease in hardness of the $S n-A I$ phase was caused by the reaction of $A l$ with Ta, reducing the Al concentration to a minimum and the hardness to that of almost pure tin. No hardness increase was found after oxidation with the pure tantalum core. Lower temperature oxidation behavior of these tin-aluminum coatings was better than the tin-free aluminum compositions. It was good enough for ten hour service but still not satisfactory by the arbitrary standards imposed here.

Different ratios of tin and aluminum were tried. A molten dip of $99 \mathrm{Sn}-1$ Al would not wet the tantalum surface to produce a $\mathrm{TaAl}_{3}$ coating. At least $3 \mathrm{Al}$ was needed to wet the surface. The $95 \mathrm{Sn}-$ 5 Al bath (G50) would give the proper coating with no gain in oxidation resistance. Coating behavior was different when the Sn-Al powders were painted on, followed by a vacuum diffusion heat treatment for $1 / 2$ to 1 hour。A $90 \mathrm{Sn}-10$ Al powder mix (G26 and G35) would not wet satisfactorily. The 50 Sn-50 Al alloy coatings (G34 and G36) did wet all surfaces of either pure Ta or the Ta-low alloy. Silver and copper powders have been substituted for tin to act as the diluent (G42 and $G 49$ ) and the Cu-Al composition shows 

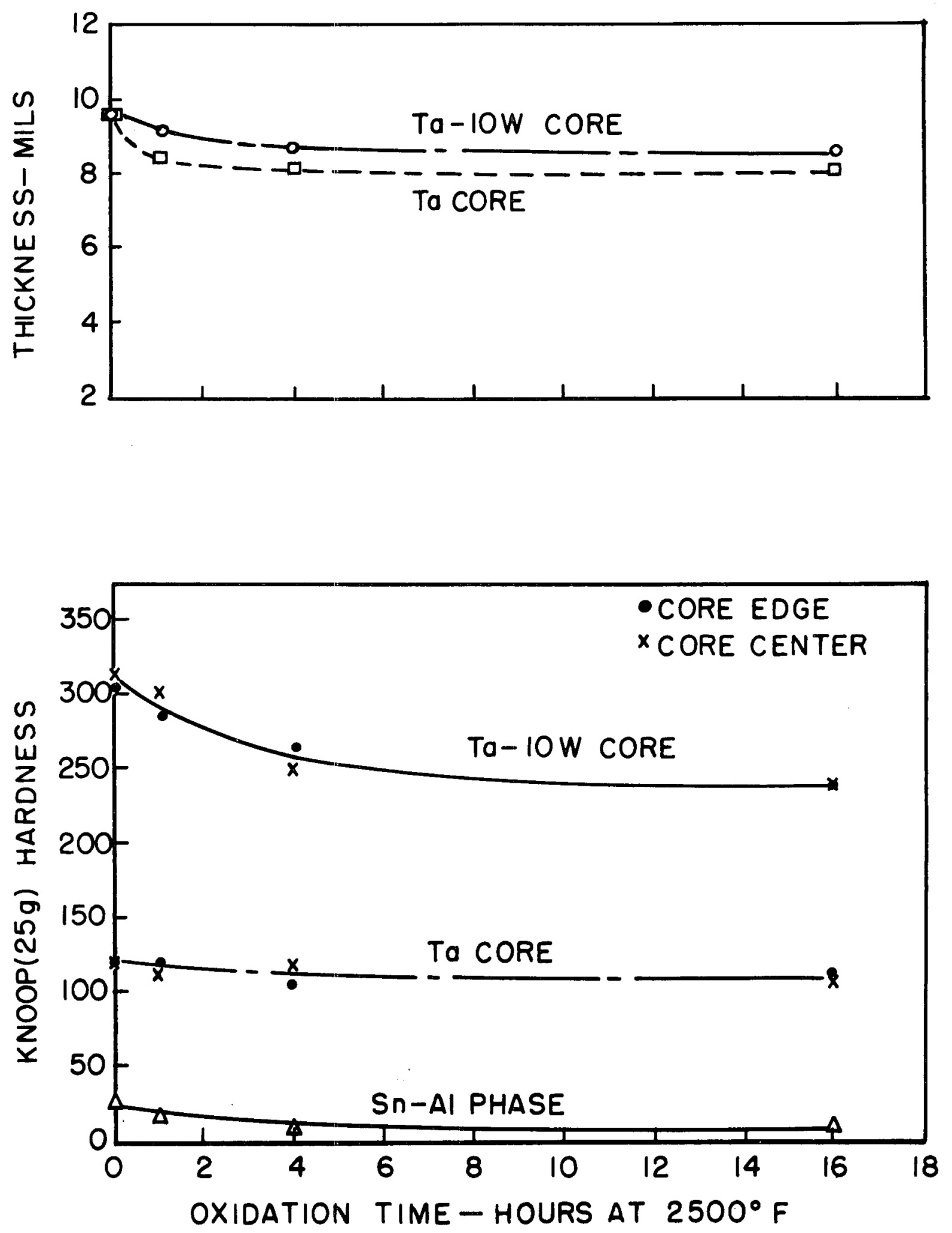

Fig. 14. Effect of time on core thickness and internal hardening of samples dip coated with Sn-10 Al. 
enough merit to warrant more work. One advantage that copper has over tin is its solubility for other metals such as titanium and chromium.

\section{B. Spray Coating}

Since dipping in a molten bath has many obvious practical limitations, other coating techniques were tried. Pack calorizing has already been discussed but no advantage could be seen by this process to produce tin-aluminum type coatings. Painting and spraying techniques look attractive. It is hard to visualize a simplex method. To concentrate effort on one composition the $50 \mathrm{tin}-50$ aluminum powder mixture using a nitrocellulose carrier was selected (G34). Preliminary oxidation results on painted and vacuum diffused samples, 1 hour at $1900^{\circ} \mathrm{F}$, showed some promise but were not outstanding. During this time period initial work was started on spraying. The effect of a number of spray passes over the sheet sample on the coating thickness followed by a vacum diffusion heat treatment after the final. spray is given in Table 3 . Furnace oxidation results at $2600^{\circ} \mathrm{F}$ on these samples are given in Table 4. Four passes give the best cyclic oxidation behavior. The microstructure of a sprayed sample is given in Figure 15. The optically active $\mathrm{TaAl}_{3}$ compound is visible on the Ta-lo W alloy substrate with a thin layer of $s n-A 1$ on the outer surface. Extreme run-ofi of molten Sn-Al alloy occurs during vacuum diffusion heat treatment which agglomerates and remains on the sample whether applied by painting or spraying techniques. This either runs off and disappears when put into the oxidation furnace or flows back onto the coated surface. Evidence of both has been detected. The samples are suspended vertically during heat treatment. Apparently surface tension holds enough coating alloy on the tantalum surface to form the required two mil coating of $\mathrm{TaAl}_{3}$ •

The next logical step was to spray with one pass of the spray gun, react by vacuum diffusion for $1 / 2$ hour at $1900^{\circ} \mathrm{F}$, respray and rediffuse. For simplicity this coating procedure is identified as 34S. Microstructures of an as-coated sample and one that had been oxidized for 10 hours with 9 cycles at $2700^{\circ} \mathrm{F}$ in a furnace without failure are shown in Figure 16. The edge of the as-coated sample shows how $\mathrm{TaAl}_{3}$ grows perpendicular to the alloy surface leaving a large void which the Sn-Al alloy fills in. All samples of either pure tantalum or Ta-10 W alloy oxidized for any time or temperature above $2000^{\circ} \mathrm{F}$ look exactly alike. The voids in the $\mathrm{Ta}_{2} \mathrm{Al}$ are filled with essentially pure tin with a dense impervious outer $\mathrm{Al}_{2} \mathrm{O}_{3}$ layer. Thermally cycled samples have the rough surface as shown by the 
TABLE 3

THICKNESS OF SPRAYED AND DIFFUSED Sn-AI

COATING ON Ta-10 W ALLOY

Thickness in mils (0,001")

\begin{tabular}{|c|c|c|c|c|}
\hline & & \multirow[b]{2}{*}{ Core } & \multirow[b]{2}{*}{ Coating } & \multirow[b]{2}{*}{ Total } \\
\hline Passes & Coating & & & \\
\hline 1 & 2.1 & 9.1 & 2.1 & 13.3 \\
\hline 2 & 2.1 & 8.9 & 2.1 & 13.1 \\
\hline 3 & 2.2 & 8.9 & 2.2 & 13.3 \\
\hline 4 & 2.5 & 8.7 & 2.5 & 13.7 \\
\hline
\end{tabular}

Samples were vacuum diffused for 1 hour at $1900^{\circ} \mathrm{F}$ after the number of passes。 
TABLE 4

FURNACE OXIDATION RESULTS ON MULTI-SPRAYED

Sn-AI COATED Ta-10 W ALLOY AT $2600^{\circ} \mathrm{F}$

Time,

Passeg

Hours

Cycles

Remarks

1

16

Good

2

$<16$

Failed

3

16

Good

4

16

Good

1

2

$I$

Failed

2

2

1

3

3

Failed

3

8

7

Failed

Good 


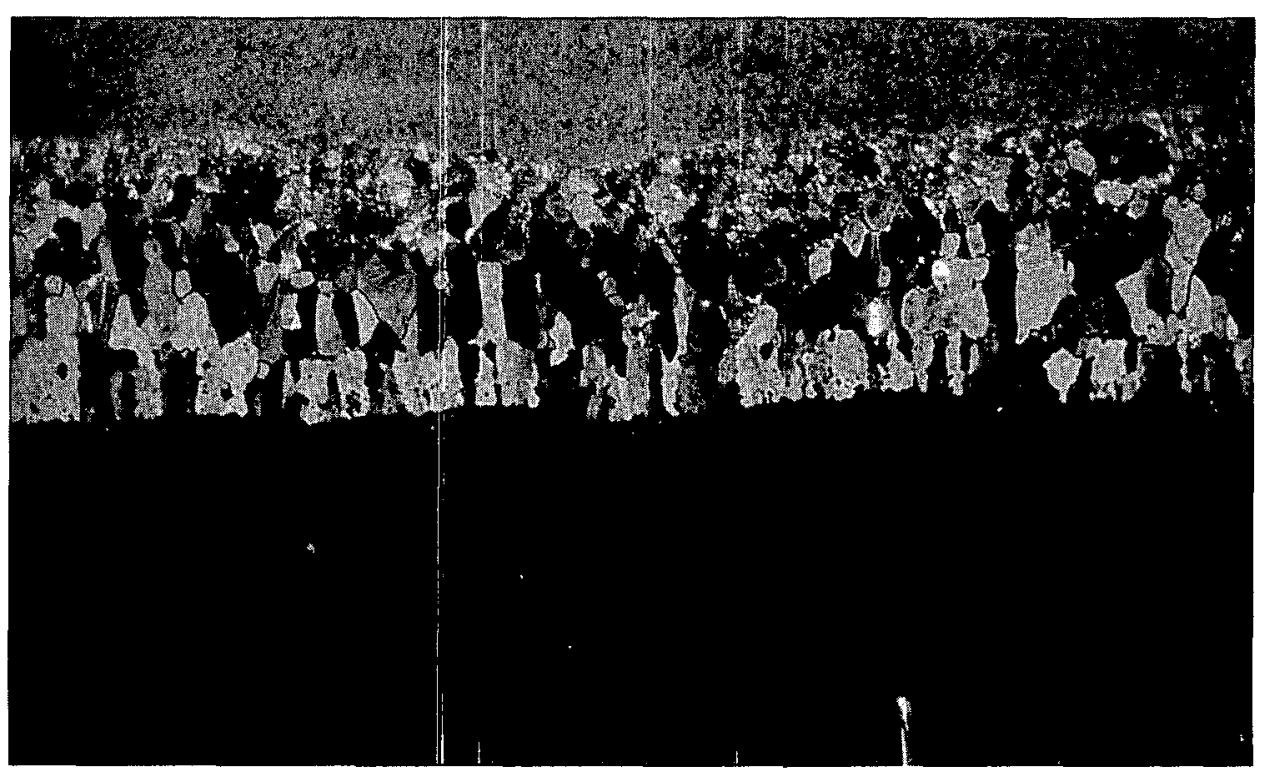

Plate No. 23941 Polarized light 500X

Sample 4TG34SVD191

Fig. 15. Spray coated four times and vacuum diffused sample of Ta-10 W alloy. 


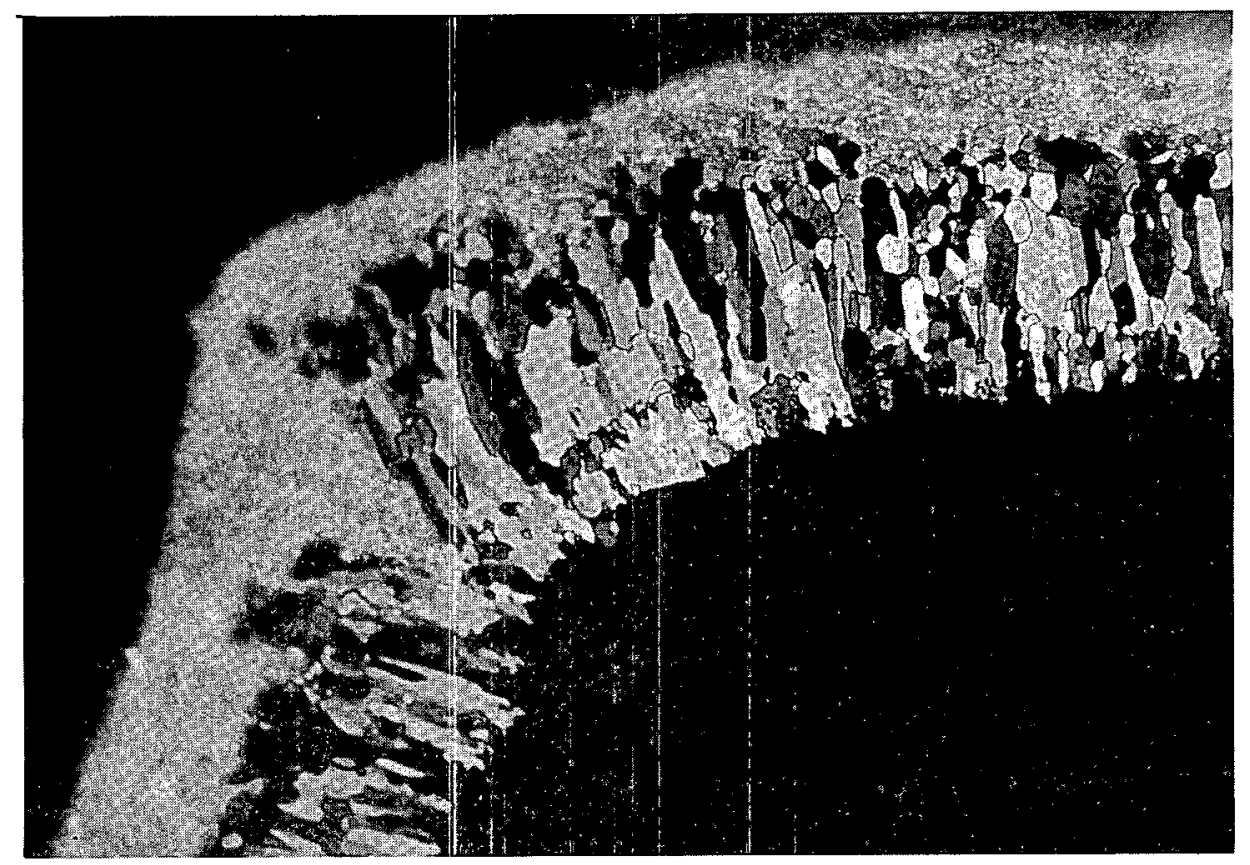

Plate No. 24025 Polarized light sample $($ TG34SVD19-1/2) 2

$500 x$

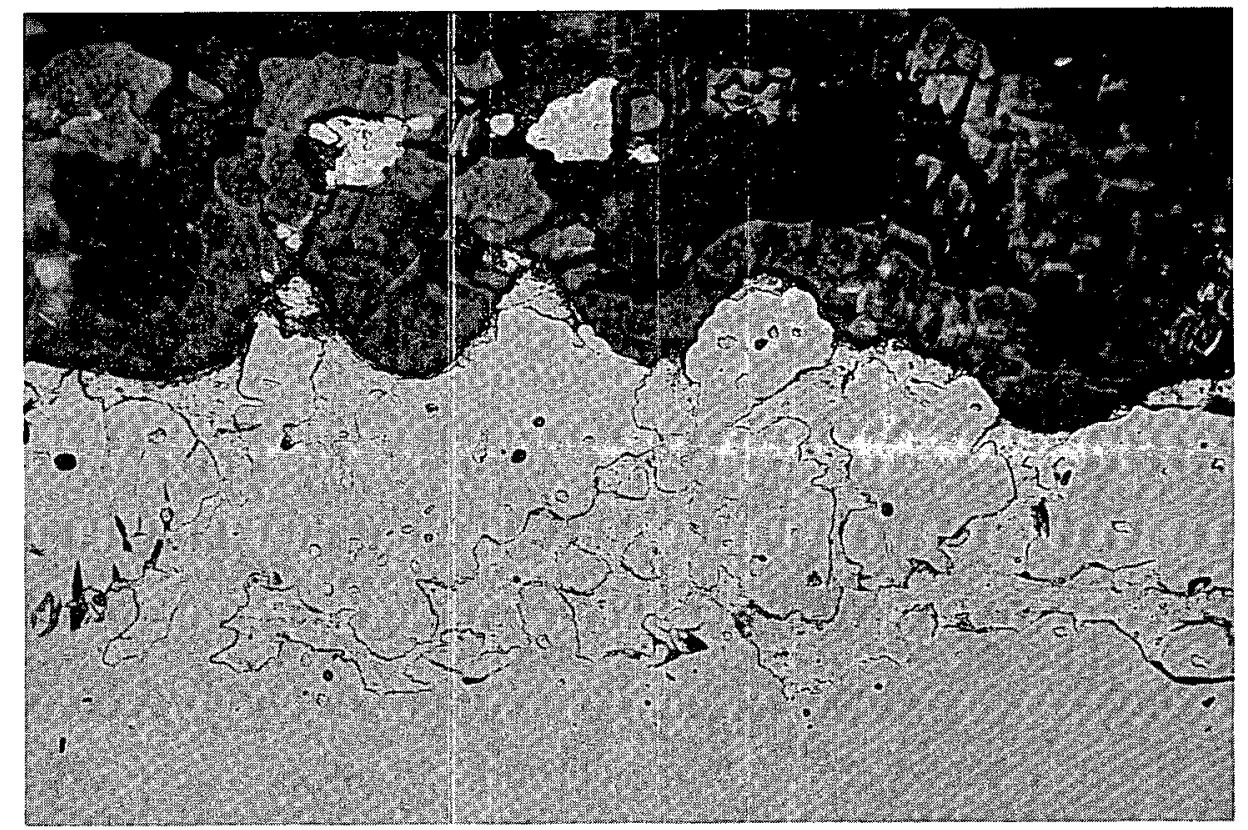

Plate No. 24026

Sample (TG34SVD19-1/2)2-23

Fig. 16. As coated and oxidized 10 hours at $2700^{\circ} \mathrm{F}$. Sample of (G34S) ${ }^{2} \mathrm{Ta}-10 \mathrm{~W}$ alloy. 
oxide contour。 This is caused by the different thermal expansion coefficients of the various components and the fact that the molten tin can relieve strains until it freezes at about $450^{\circ} \mathrm{F}$. Samples oxidized isothermally have a smooth oxide surface。

All of the furnace oxidation test results using the $34 \mathrm{~S}$ composition are given in Table 5. This coating system meets all of the requirements of oxidation protection for lo hours with a minimum of 10 thermal cycles in the temperature range of $2500^{\circ}-2800^{\circ} \mathrm{F}$ quite easily. A more reasonable evaluation is 100 hour life at any temperature or any combination of temperatures between $-320^{\circ} \mathrm{F}$ to $2800^{\circ} \mathrm{F}$ for the Ta-10 W alloy. Oxidation results up to $2950^{\circ} \mathrm{F}$ are also noteworthy. Coated samples were cooled to $-320^{\circ} \mathrm{F}$ for 1 hour, oxidized for 4 hours at $2800^{\circ} \mathrm{F}$, kept at $-320^{\circ} \mathrm{F}$ for 16 hours and reoxidized for 4 hours at $2500^{\circ} \mathrm{F}$ without failure or any formation of "tin pest"。

\section{Battelle Alloys}

Battelle Memorial Institute has developed two tantalum base alloys which have certain advantages. One has lower density, Ta$30 \mathrm{Cb}-7.5 \mathrm{~V}$, and the second, $\mathrm{Ta}-10 \mathrm{H} \hat{x}-5 \mathrm{~W}$, has good elevated temperature properties. The first alloy was produced in button form at sylcor and cold rolled to $10 \mathrm{mil}$ thick sheet. Coated samples gave poor oxidation results which are given in Table 6. This alloy reacts faster with the aluminum than other tantalum materials and behaves more like a columbium alloy.

The second alloy was received from Battelle and cold rolled to $10 \mathrm{mil}$ thick sheet. The furnace oxidation results are also listed in Table 6. Initial work using the $34 \mathrm{~s}$ coating revealed an unknown added phase next to the core material. Reaction rates are faster also. These coated alloys will be discussed further in the next section.

\section{D。 Bend Ductility and Diffusion Rates}

To determine diffusion rates and effect of oxidizing conditions on bend ductility of coated tantalum materials, coupons of 10 and 25 mil thick pure tantalum sheet and 10 mil thick sheet of the Ta-10 W alloy and the two Battelle alloy compositions were coated with G 21 and 345 . Samples were oxidized for 1,5 , and 16 hours at $2500^{\circ}$ and $2600^{\circ} \mathrm{F}$. It was found that the coated Ta-lo W alloy would not take a bend without cracking through. This is indicative of a highly notch sensitive alloy since no internal hardening and little 
TABLE 5

FURYACE OXIDATIOIJ RESULTS ON $34 \mathrm{~S}$ COATED Ta-10 W ALLOY

$\begin{array}{ll}\text { Sime, } & \\ \text { Sample } & \text { Hoours }\end{array}$

$\underline{2} \underline{960^{\circ}} \underline{\text { Tiests }}$

$\begin{array}{crrr}34 & 3 & & \text { Good } \\ 162 & 6 & 5 & \text { Good } \\ 163 & 6 & 5 & \text { Good } \\ 36 & 3 & 7 & \text { Good } \\ \text { Flame sample } & 10 & 9 & \text { Failed at llole } \\ 35 \text { and 35A } & 16 & & \text { Good } \\ 130 & 64 & & \text { Good } \\ 131 & 64 & & \text { Good } \\ 158 & 65 & 65 & \end{array}$

$\underline{2 S 00^{\circ}}{ }^{\text {F Test }}$ S

\begin{tabular}{|c|c|c|c|}
\hline 26 & 6 & 5 & Failure Due to Mishandling \\
\hline 25 & 3 & 7 & Failure Due to Mishandling \\
\hline 70 & 10 & 9 & Good \\
\hline 71 & 23 & 22 & Good \\
\hline 33 & $>_{40}<44$ & 3 & Failed \\
\hline 54 & 52 & 6 & Failed \\
\hline 55 & 56 & 7 & Good \\
\hline 42 & 64 & & Good \\
\hline 67 & 65 & & Good \\
\hline 39 & $>80<96$ & 7 & Failed \\
\hline 77 & 112 & & Good \\
\hline
\end{tabular}

\section{0 $\underline{0}^{\circ}$ Tests}

\begin{tabular}{|c|c|c|c|c|}
\hline \multicolumn{2}{|c|}{23} & 10 & 9 & Good \\
\hline & 24 & 10 & 9 & Corner Failure \\
\hline & 27 & $<16$ & & Failed \\
\hline 28 & and 29 & 16 & & Good \\
\hline & 66 & 63 & 7 & Failed \\
\hline 30 & and 31 & 64 & & Good \\
\hline & 52 & 77 & 9 & Failed \\
\hline
\end{tabular}


TABLE 5 (Cont'd.)

FURNACE OXIDATION RESULTS ON 34 S COATED Ta-10 W ALLOY

\begin{tabular}{|c|c|c|c|}
\hline Sample & $\begin{array}{l}\text { Time, } \\
\text { Hours }\end{array}$ & Time, & Renaris \\
\hline \multicolumn{4}{|c|}{ 2700 $0^{\circ}$ Fests $\left(\right.$ Cont $\left.\mathrm{d}_{0}\right)$} \\
\hline 53 & 80 & 10 & Failed \\
\hline 64 & 95 & 6 & Failed \\
\hline 65 & 110 & 7 & Failed \\
\hline \multicolumn{4}{|c|}{$\underline{2600^{\circ}}{ }^{\mathrm{F} \text { Tests }}$} \\
\hline 22 & 5 & 4 & Good \\
\hline 21 & 16 & & Good \\
\hline 24 & 16 & & Good \\
\hline 62 & 100 & 10 & Failed \\
\hline 63 & 100 & 10 & Failed \\
\hline 68 & 120 & 12 & Failed \\
\hline 69 & 120 & 12 & Failed \\
\hline
\end{tabular}

$\underline{2500^{\circ} \mathrm{F} \text { Tests }}$

$20 \quad 16$

$49 \quad 80$

$50 \quad 92$

$32 \quad 112$

$40 \quad 152$

$94 \quad 188$

$56 \quad 203$

$41 \quad 216$

$57 \quad 256$

$51 \quad 368$

47

48

58

59
136

240

288

288

2
3
8
8
20
13
23
30

Good

Failed

Failed

Good

Failed

Good

Failed

Corner Failure

Failed

Failed

\section{$\underline{2} 200^{\circ}$ F Tests}


TABLE 5 (Cont'do)

FURNACE OXIDATION RESULTS ON 345 COATED Ta-10 W ALLOY

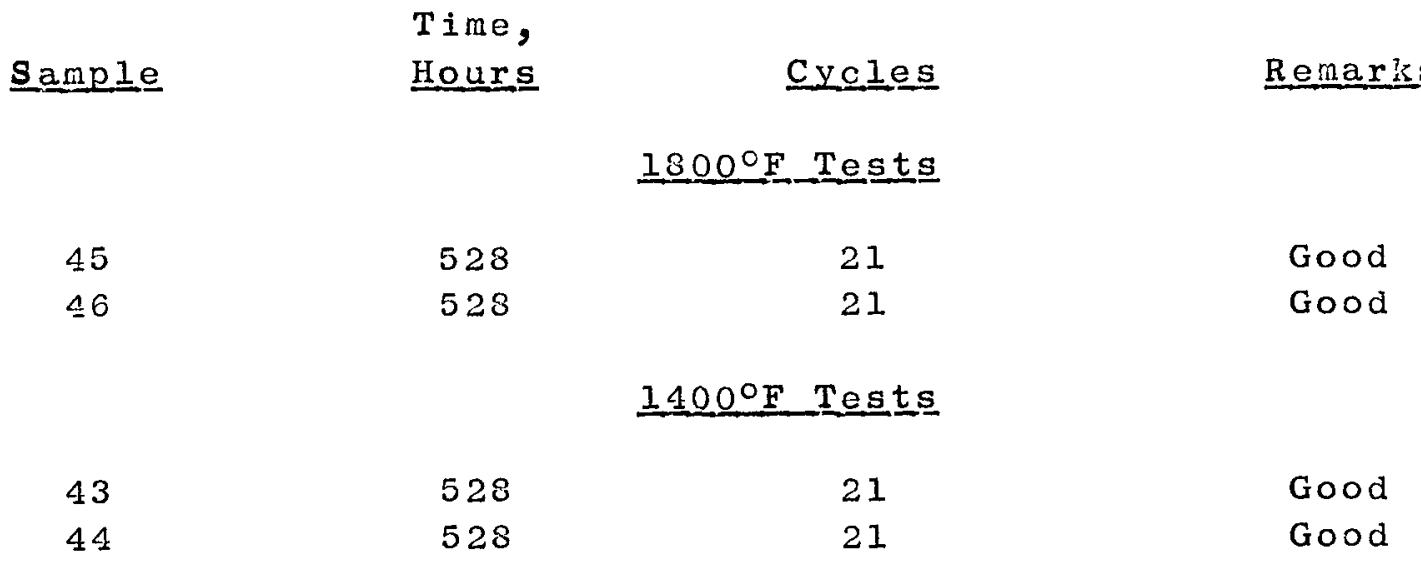


TABLE 6

FURNACE OXIDATION RESULTS ON COATED BATTELLE ALLOY SHEET

Coating

$\mathrm{Ta}-30 \mathrm{Cb}-7.5$ V A110y

G 21

G 21

G48 with G34 overlay

G 21

G 21

G 21

G21

G48 with G34 overlay

G 21

G 48 with G34 overlay

Ta-10 Hf-5 W

$36 S$

$36 \mathrm{~S}$

345

$34 \mathrm{~S}$

$34 \mathrm{~S}$

$36 \mathbf{S}$

$3 \pm S$

Time,

Hours

Cycles

$\underline{2500^{\circ} \mathrm{F} \text { Tests }}$

8
$<16$
10

1

9

26000F Tests

8
16
5
$<16$
$<16$

\section{$2700^{\circ} \mathrm{F}$ Tests}

3
$<7$

$2500^{\circ} \mathrm{F}$ Tests

33

64

10

38

88
1

4

2

Failed

Failed
Good Good

Failed

Failed

Failed

Good

Good

$2700^{\circ} \mathrm{F}$ Tests

12

6

10

12

10
Good Through Core Coating Diffused Good Good

Failed
$<16$

16
Failed

Failed 
diffusion takes place during coating. A sample of the alloy with the same heat treatment was found to bend without any change in hardness, $235 \mathrm{VPN}$. Bend ductility tests indicated little harmful effect of internal contamination with the G21 coating on 10 mil tantalum. They were ductile in a roon temperature bend of $90^{\circ}$ over a $4 \mathrm{~T}$ radius after up to 16 hours exposure at $2500^{\circ} \mathrm{F}$ and $2600^{\circ} \mathrm{F}$. The coating itself cracked but the crack did not propasate appreciably into the substrate. This is shown in Figure 17.

Reaction rates are given in Table 7 for most of the samples with the G2I coating. Thickness data with the G21 coating show little significant difference between Ta or Ta-10 W alloy. The metal reacts with all of the available aluninum with no additional decrease in core thickness. The effect of excess aluminum in the $34 \mathrm{~S}$ composition with the three tantalum materials is given in Table 8. With most oxidization conditions the Ta-10 If $-5 \mathrm{~W}$ alloy had no core left. The harmful effect of the run-off remaining on the samples is evident also. The area of the excess $S \mathrm{n}-\mathrm{Al}$ has reacted with all of the Ta-10 W alloy core in certain cases. Measurenents were made at the top of the sample, middle, and the bottom area with the run-off. Obviously the excess must be removed before test。 This can be done quite easily depending on the geometry of the sample. One way is to heat the sarple to a black heat, enoush to melt tin $\left(450^{\circ} \mathrm{F}\right)$, and shake or wipe it off。

\section{En Oxidation Rates}

Prior work has shown that the 34 S coating would meet the proposed oxidation requirenents and it was felt desirable to obtain weigint gain data as a funotion of time and temperature. Tests were conducted on coated Ta-lo $\mathrm{W}$ alloy at $1300^{\circ}, 2200^{\circ}, 2500^{\circ}$, and $2300^{\circ} \mathrm{F}$. The results are listed in Table 9 and plotted in Figure 18. Thermal cycling accelerates oxidation by a factor of two or more。 At $1800^{\circ}$ and $2200^{\circ} \mathrm{F}$ the samples lose weight because of the run-off of excess Sn-A1. But at $2500^{\circ}$ and $2800^{\circ} \mathrm{F}$ no loss in weight occurs, indicating that the excess coating runs back up onto the surfaces. With this coating, weight gain data gives no indication of protectiveness since the Ta-10 Hf-5 W alloy oxidizes at a lesser rate than the Ta-lo W alloy but has markedly poorer oxidation resistance; it fails sooner, presumably because of rapid diffusion. 


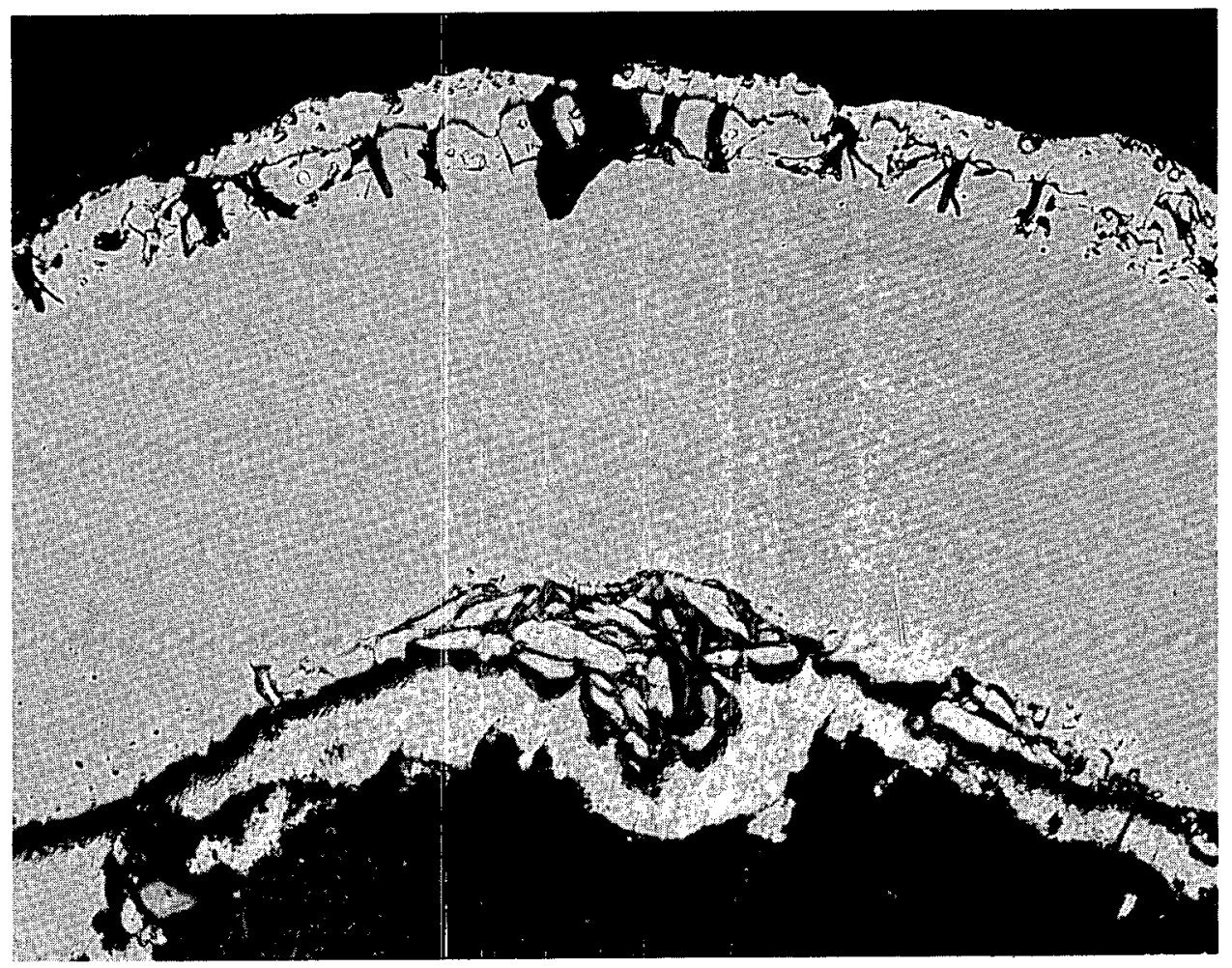

Plate No. 23985

Fig. 17. Overall view of bend area, oxidized sixteen lours at $2600^{\circ} \mathrm{F}$ - Coating Sn-10 Al dip. 
TABLE 7

DIFFUSION EFFECTS ON G21 COATED TANTALUM MATERIALS

Thiclsness in mils $(0,001 ")$

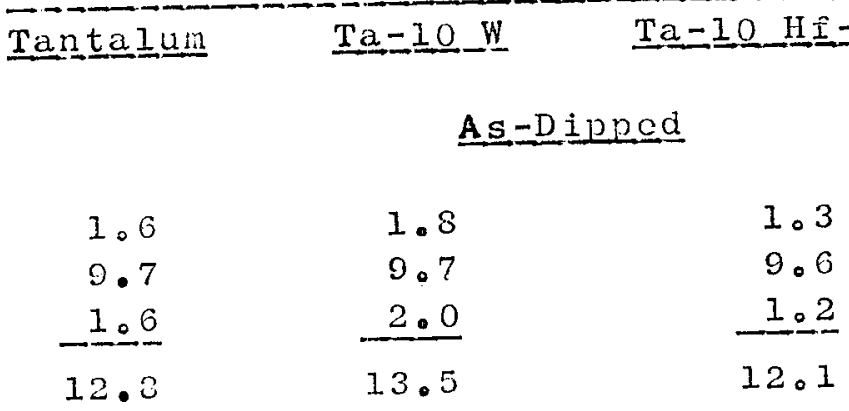

Coating

Core

coating

Total

I L LOU

Coating

core

$2 \cdot 1$

9.2

coatinc

$\underline{2.3}$

Total

13.6

$\begin{array}{r}2.0 \\ 3.4 \\ 3.0 \\ \hline 14.9\end{array}$

2.8

2.0

7.0

3.0

$2 \circ 7$

1409

13.4

\section{Hours 2500을}

Coatins

Core

2.7

8.7

coating

2.5

Total

13.0

2.3

2.6

3.1

7.4

2.0

2.7

13.5

12.7

16 Hours 2 므으요

Coatins

Core

2.6

3.7

3.3

3.1

Failed

Coating

2.5

$-3.5$

Total

13.3

$1 \approx 00$

\section{1 프으믄 2600음}

Coating

core

2.5

2.3

9.3

8.4

Failed

coating

Total

$\frac{2.9}{14.7}$

2.9

14.1 
TABLE 7 (Cont'd•)

DIFFUS ION EFFECTE ON G21 COATED TANTALUM MATER IALS

Thickness in mils $(0,001 ")$

Tantalum $\underset{\text { Ta-10 W }}{\text { Thours } 2600^{\circ} \mathrm{F}}$

$\begin{array}{lrr}\text { Coating } & 2.5 & 3.6 \\ \text { Core } & 8.7 & 8.4 \\ \text { Coating } & 2.8 & 3.4 \\ \text { Total } & 14.0 & 15.4\end{array}$

16 Hours $2600^{\circ} \mathrm{F}$

$\begin{array}{lrrr}\text { Coating } & 3.3 & 2.6 & 2.5 \\ \text { Core } & 8.4 & 8.2 & 6.7 \\ \text { Coating } & 3.8 & 2.8 & 2.2 \\ \text { Total } & 15.5 & 13.6 & 11.4\end{array}$


TABLE 8

DIFFUSION EFFECTS ON $34 \mathrm{~S}$ COATED TANTALUM MATERIALS

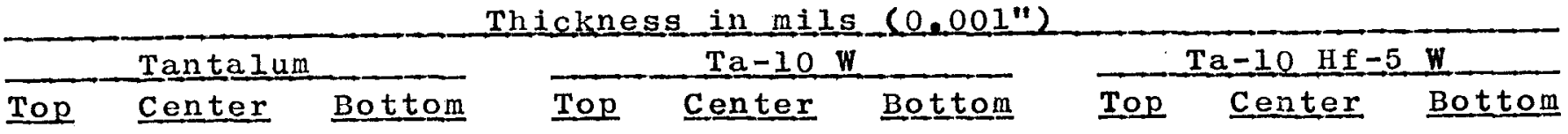

As Coated

Coating

\section{Core}

Coating

Total

$\overleftrightarrow{0}$

$\begin{array}{lrrr}\text { Coating } & 8.1 & 16.1 & 12.4 \\ \text { Core } & 21.0 & 19.0 & 16.0 \\ \text { Coating } & 8.7 & \frac{10.5}{45.6} & \frac{12.4}{40.8} \\ \text { Total } & 37.8 & \end{array}$

$\mp$

0

\begin{tabular}{rrrr}
3.5 & 3.7 & 6.2 & 3.2 \\
5.8 & 5.7 & 5.8 & 8.6 \\
3.2 & 3.7 & 6.2 & 3.0 \\
\hline 12.5 & 13.1 & 18.2 & 14.8
\end{tabular}

1 Hour $2500^{\circ} \mathrm{F}$

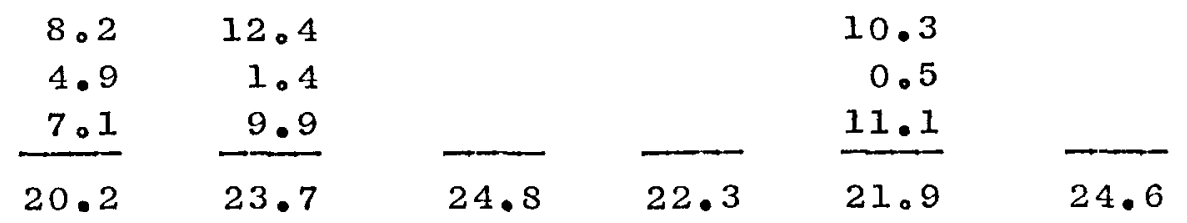

5 Hours $2500^{\circ} \mathrm{F}$

\begin{tabular}{|c|c|c|c|c|c|c|c|c|c|}
\hline coating & 14.8 & 17.6 & 16.8 & 5.7 & 10.0 & & & & \\
\hline Core & $12 \cdot 4$ & $12 \cdot 4$ & 12.4 & 4.6 & 1.0 & & & & \\
\hline Coating & 17.6 & 17.6 & 19.8 & 7.4 & 14.8 & & & & \\
\hline Total & 44.8 & $47 \cdot 6$ & 49.0 & $17 \cdot 7$ & 25.8 & 24.8 & 24.8 & 24.8 & 24.8 \\
\hline \multicolumn{10}{|c|}{16 Hours $2500^{\circ} \mathrm{F}$} \\
\hline Coating & 9.9 & 12.4 & 13.8 & 8.7 & 11.9 & & & & \\
\hline Core & 19.3 & 17.3 & 16.0 & 3.3 & 1.7 & & & & \\
\hline Coating & 9.9 & 11.6 & $\underline{12 \cdot 4}$ & 9.9 & $\underline{11.4}$ & - & & & \\
\hline Total & 39.1 & 41.3 & $42 \cdot 2$ & 21.9 & 25.0 & 25.0 & & & \\
\hline
\end{tabular}




\section{TABLE 8 (Cont'do)}

DIFFUS ION EFFECTS ON 345 COATED TANTALUM MATER IALS

\begin{tabular}{|c|c|c|c|c|c|c|c|c|}
\hline \multicolumn{3}{|c|}{ Tanta 1 um } & \multicolumn{3}{|c|}{$\mathrm{Ta}=10 \mathrm{~W}$} & \multicolumn{3}{|c|}{$\mathrm{Ta}-10 \mathrm{Hf}-5 \mathrm{~W}$} \\
\hline Top & Center & Bottom & Top & Center & Bottom & Top & Center & Bottom \\
\hline
\end{tabular}

\begin{tabular}{lrrrrrr} 
Coating & 7.4 & 9.2 & 9.9 & 10.8 & 12.4 & \\
Core & 20.4 & 19.8 & 18.6 & 3.0 & 2.0 & \\
Coating & 8.7 & 9.9 & 11.0 & 11.6 & 12.4 & \\
\cline { 2 - 4 } & 36.5 & 38.9 & 39.5 & 25.4 & 26.8 & 37.7
\end{tabular}

5 Hours $2600^{\circ} \mathrm{F}$

\begin{tabular}{|c|c|c|c|c|c|c|c|}
\hline \multirow{4}{*}{ gr } & Coating & 11.6 & 12.4 & 12.6 & 7.4 & 8.9 & 11.2 \\
\hline & Core & 19.8 & 18.6 & 16.0 & 6.0 & 4.9 & 1.2 \\
\hline & Coating & 9.9 & 11.9 & $12 \cdot 6$ & 5.7 & 8.8 & 12.4 \\
\hline & Total & 41.3 & 42.9 & 41.2 & 19.1 & 22.6 & 24.8 \\
\hline
\end{tabular}

16 Hours $2600^{\circ} \mathrm{F}$

$\begin{array}{lrrrrrr}\text { Coating } & 7.4 & 12.4 & 12.4 & 16.8 & 11.9 & \\ \text { Core } & 19.8 & 15.8 & 14.8 & 2.5 & 1.1 & \\ \text { Coating } & 7.2 & 12.4 & 13.4 & 11.6 & 11.9 & - \\ \text { Total } & \mathbf{3 4 . 4} & 40.6 & 40.6 & 30.9 & 24.9 & 24.8\end{array}$


TABLE 9

OXIDATION WEIGHT CHANGE OF 348 COATED Ta-1O W ALLOY

Temperature, ${ }^{\circ} F$

Time,

Houㅡㅁㅗ

\begin{tabular}{|c|c|c|c|}
\hline & Cycled & 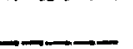 & Isotherma1 \\
\hline 1300 & 2200 & 2300 & 2500 \\
\hline
\end{tabular}

Weight Change in MIIIigrams

1
2
4
8
24
46
70
100

-5.1
-2.9
-13.2
Failed

$-0.5$

$-0.8$

3.2

5.8

6.6

$-0.3$

8.5

9.8

0.2

16.2

16.1

0.8

34.1

27.3

42.4

62.5

47.6

Failed

$\underline{T} \underline{a}=10 \quad$ Hf -5 W Alloy

1
2
4
8
24

$$
\begin{array}{r}
2.3 \\
3.9 \\
7.6 \\
10.3 \\
20.3
\end{array}
$$

Sample Size $\quad-0.5^{\prime \prime} \times 0.75^{\prime \prime} \times 0.10^{\prime \prime}$ uncoated. Coated Weights - 1.2 to 1.5 grams。 


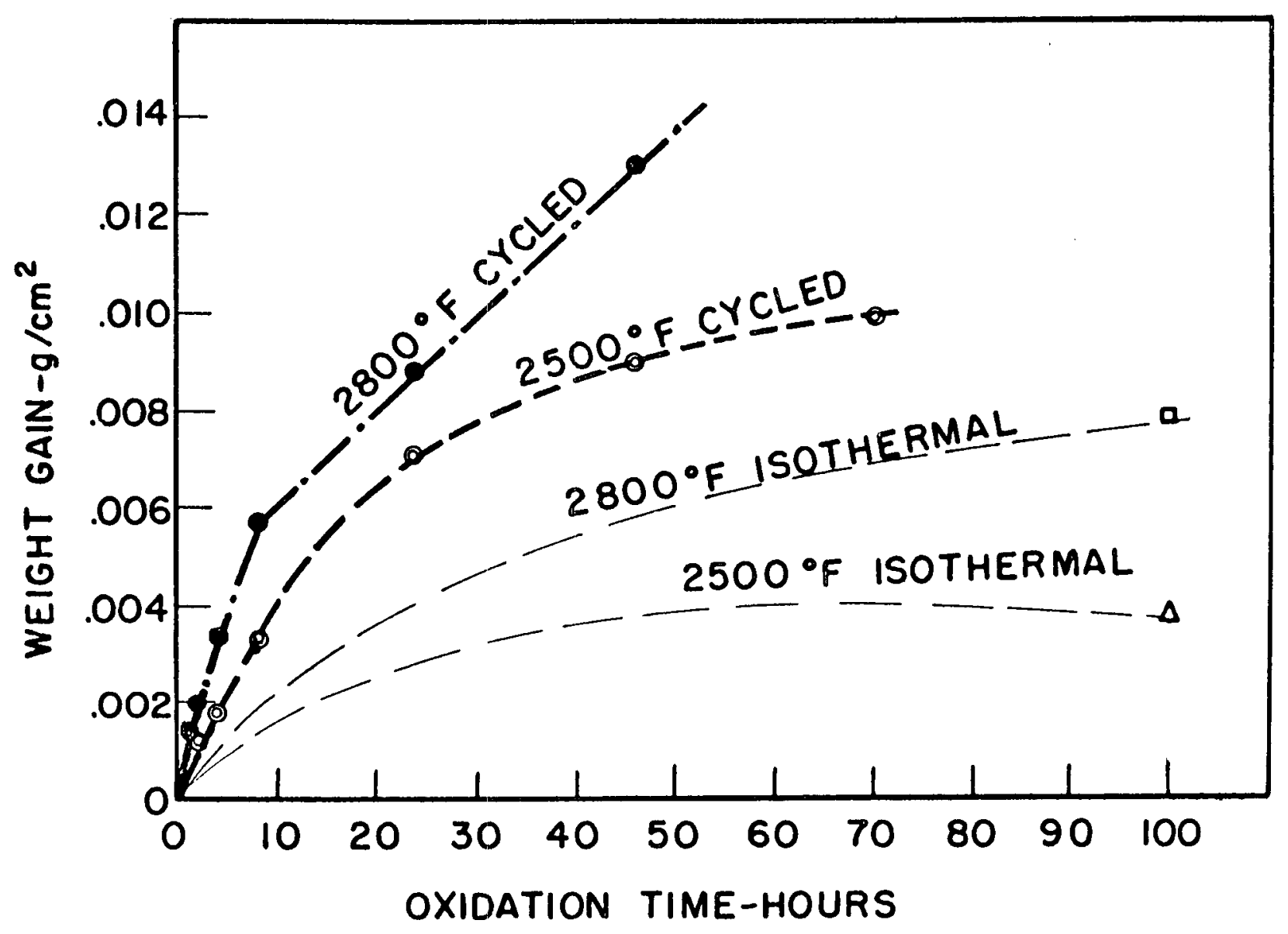

Fig. 13. Weight gains of $34 \mathrm{~S}$ coated Ta-lo $\mathrm{W}$ alloy samples oxidized at $2500^{\circ}$ and $2800^{\circ} \mathrm{F}$. 


\section{F. Electrically Heated Oxidation Data}

Direct resistance heating was used to evaluate many coating compositions。 Two machines were powered by DC current and two by AC current. At first no difference in oxidation results was attributed to AC or DC current. Many samples oxidized and failed in the cooler regions and were classified as cold zone failures, as opposed to those that failed in the hot zone. This could be justified by the poor low temperature oxidation properties of aluminum compositions. But when testing Sn-Al compositions too many duplicate tests were failing at short times in the cold zone. Samples also appeared to be embrittled. The effect of DC and AC power on $34 \mathrm{~S}$ coated Ta-10 W samples is evident in Table 10. A "knuckle" of material is formed at the negative electrode in DC tests no matter if it is at the top or bottom of the fixture and premature failure occurs at this area. Mass transfers occur by electrolytic action. All of the Ta alloy reacts with Al to form $\mathrm{Ta}_{2} \mathrm{Al}$ across the entire cross-section forming the "knuckle". Therefore only AC heated results are valid. These tests do show that the 345 coating can withstand up to 100 cycles in the temperature range of $2500^{\circ}-2800^{\circ} \mathrm{F}$.

\section{G. Creep Oxidation}

To get a better engineering viewpoint with respect to size effects and ability to withstand mechanical stress and resultant strain on coated samples, larger creep samples were fabricated, coated, and oxidation tested. The specimens were welded together using 6" long strip of the Ta-lo W alloy with a final size of $0.010^{\prime \prime}$ thick by $1 "$ wide $x 18^{\prime \prime}$ long. Tabs were spot welded along the side for creep measurement purposes. Holes were punched in the cold ends for gripping. The creep results obtained are listed in Table 11. The coating on the first eight samples was painted on, the balance were sprayed. More extensive work needs to be done in this area. Although a few samples would last 10 hours at temperature with more than $2 \%$ strain, different results were obtained in different furnaces. A better explanation for the random results is that a larger vacuum furnace had to be used for diffusion heat treatments. The heating rate is slower, which could have a harmful effect. Actually no explanation can be given at the present time.

\section{H. Flame Oxidation Tests}

Another screening test used to evaluate coating, especially at temperatures difficult to obtain by more conventional means, was 
TABLE 10

DIRECT RESISTANCE HEATED OXIDATION RESULTS ON $34 S$ COATED Ta-10 W ALLOY

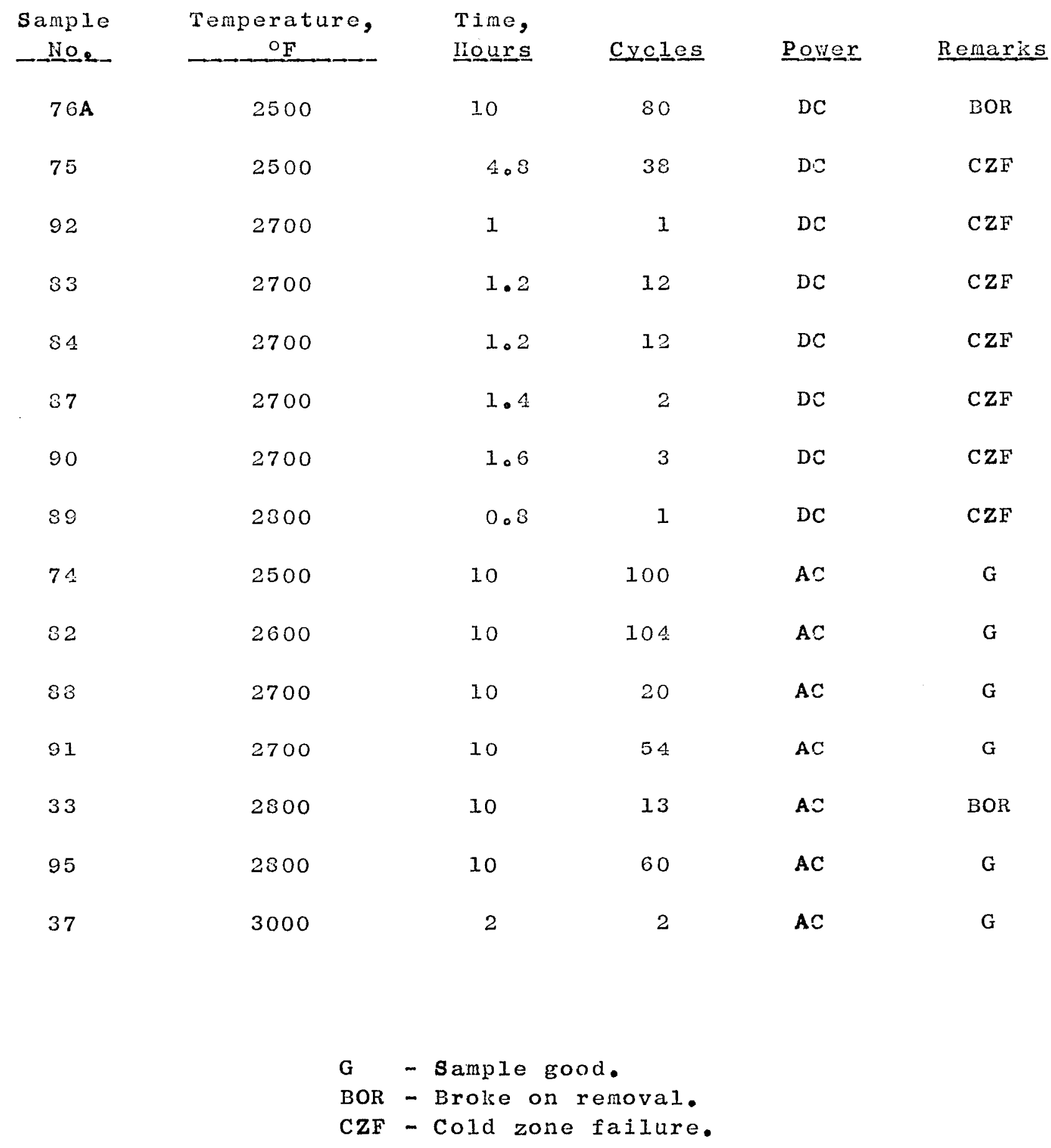


TABLE 11

\section{CREEP REBULTS ON COATED Ta-10 W ALLOY}

Sample $\quad \begin{gathered}\text { Time, } \\ \text { Hours }\end{gathered} \quad$ Cycles $\frac{\begin{array}{c}\text { Stress, } \\ \text { psi }\end{array}}{2500^{\circ} \text { F Tegtg }}$

G 34 Coating

\begin{tabular}{|c|c|c|c|c|c|c|}
\hline $\mathrm{SR}$ & 1 & 9 & & 1300 & & Gr1p Broke \\
\hline $\mathbf{B R}$ & 2 & 6 & 1 & 5700 & 5 & Fatled \\
\hline $8 R$ & 3 & 8.5 & & 4300 & 6 & Good \\
\hline $8 R$ & 4 & 10 & & 4300 & 2 & Good \\
\hline $\mathbf{8 R}$ & 5 & 6.5 & 3 & 4300 & $\theta$ & Fatled \\
\hline $\mathbf{g R}$ & 6 & 7 & 3 & 2500 & 0.3 & Falled \\
\hline $\mathbf{B R}$ & $\theta$ & 6.7 & 3 & 2800 & & Falled \\
\hline $\mathbf{S R}$ & 10 & 0.5 & & 3200 & & Falled \\
\hline $\mathbf{8 R}$ & 11 & 5 & 3 & 2500 & & Falled \\
\hline $\mathbf{8 R}$ & 12 & 6 & 3 & 2700 & & Fa1led \\
\hline
\end{tabular}

SR 7

8.5

8R 8

1.5

4

G_22 coating

2000

2

Falled

2100

0.4

Falled

\section{Coat1ng}

$\begin{array}{llr}\text { SR } & 13 & 10 \\ \text { SR } & 14 & 7 \\ \text { SR } & 16 & 10 \\ \text { SR } & 16 & 0\end{array}$

5

3

10

7

\section{T Teat}

349-Cort1na

SR 17
B. 7

4
2600
3100
Good

Falled

Good

Orip Broko

Ta110d 
the flame test. At first a curved sample was used with the flame from a small oxidizing oxy-acetylene torch impinging against the convex surface. With our coatings it was felt that using a flat sample, $I^{\prime \prime} \times 2^{\prime \prime} \times 0.010^{\prime \prime}$, and a multi-flame torch that a larger area would be heated thereby giving a more representative result. The flame test can only be used to compare coating compositions relative to each other. The results obtained are given in Table 12. Once again thermal cycling causes more rapid failure as compared to isothermal conditions. Nevertheless certain coatings are capable of meeting the requirements of the programo of more importance is the ability of $\mathbf{S n - A}$ l compositions to withstand temperatures about $3000^{\circ} \mathrm{F}$ for practical time periods.

\section{Arc-Plasma Tests}

The $34 \mathrm{~s}$ coating surpassed original requirements. The primary question was what would happen to this coating with its liquid second phase in potential service conditions? of course the answer would eventually be found by testing it in hypersonic and/or space flight. A popular first approach to duplicating re-entry conditions is the arc-plasma jet. Therefore, samples of 348 coated Ta$10 \mathrm{~W}$ alloy were prepared and so tested. The test schedule and results are shown in Table 13. These serve to add further proof that the coating is protective in a relatively fast moving hot air stream to temperatures above $2800^{\circ} \mathrm{F}$ and is.also resistant to thermal cycling. The cyclic results also indicate good reproducibility. The tests were run at the University of Dayton Research Institute and the test conditions were arbitrarily selected by them.

Several optical devices were used for temperature measurements and preliminary indications were that the coatings had a relatively high emissivity. However, no numerical values for this were given.

Comparison tests at sylcor were made using an optical pyrometer and a shawmeter, an instrument claimed to give true temperature regardless of emissivity, atmospheric conditions, etc. These tests also indicated an emissivity value close to unity for the oxidized 345 coating. This is another area that requires more study。

\section{COLUMBIUM OXIDATION RESULTS}

A secondary part of this investigation was to determine how the better tantalum coatings performed when applied to columbium 
TABLE 12

FLAME OXIDATIOH TEST RESULTS ON COATED Ta-10 W ALLOY

Time,

Sample
Temperature, of

Cycles

Curved Samples
8

8

4.7

2.7
G21-5

G 21-10

G $21-9$

G 21-3

G 21-11

G 21-7

G 21-6

G $21-1$

G $21-5$

G 21-3

G 21-2

G21-4

GIs-3

G $1 \leq-1$

G14-2.

G $11-4$

G $\leq 1-3$

G $41-2$

G $41-1$

G $47-4$

G $47-3$

G $47-1$

G $47-2$
8

3.8

2.3

0.3

1

1.2

7.5

7.7

4.5

0.01

0.3

7.5

10

0.1

3

1.7

0.3

1.7

6.5

1.5

0.5

1.5
2700

2700

2300

3000

\section{Flat Samples}

$\begin{array}{ll}8 & 2500 \\ 4 & 2700 \\ 2 & 2800 \\ 3 & 3000 \\ 1 & 3000 \\ 1 & 3000 \\ & 3000 \\ & 3000 \\ 1 & 3200 \\ & 3400 \\ & 3400\end{array}$

Remarks

Good Good

Failed

Failed

Good

Failed

Failed

Failed

Failed

Failed

Good

Good

Failed

Failed

Failed

Good

Good

Failed

Good

Failed

Failed

Failed

Failed

Failed

Failed

Failed 
TABLE_I2 (Cont'd.)

FLAME OXIDATION TEST RESULTS OH COATED Ta-10 W ALLOY

Sample $\quad \begin{aligned} & \text { Time, } \\ & \text { Fours } \quad \text { cycles }\end{aligned}$

\begin{tabular}{|c|c|c|c|c|c|}
\hline $\mathrm{G} 40$ & Paint -1 & 5.5 & 5 & 2700 & Good \\
\hline G 40 & Paint -2 & 4 & 4 & 3000 & Good \\
\hline $\mathrm{G} 40$ & Paint -3 & 3 & 3 & 3000 & Failed \\
\hline G 40 & Pain $t-4$ & 7.5 & 8 & 3000 & Failed \\
\hline $\mathrm{G} 40$ & spray -4 & 4.8 & 5 & 2500 & Failed \\
\hline $\mathrm{G} \triangle 0$ & spray -3 & 2.7 & 2 & 2300 & Failed \\
\hline G 40 & spray -2 & 1 & 1 & 3000 & Failed \\
\hline $\mathrm{G} \triangle 0$ & Spray -1 & 1 & 1 & 3000 & Failed \\
\hline 405 & -16 & 2 & 8 & 3000 & Good \\
\hline 405 & -13 & 0.15 & & 3180 & Failed \\
\hline 405 & -17 & 0.5 & 2 & 3180 & Failed \\
\hline 405 & -11 & 1.7 & 3 & 3180 & Failed \\
\hline $40 \mathrm{~S}$ & -12 & 2 & 2 & 3180 & Failed \\
\hline $40 \mathrm{~S}$ & -13 & 1.3 & & 3270 & Failed \\
\hline $34 \mathrm{~S}$ & & 8 & 3 & 2500 & Good \\
\hline $34 \mathrm{~S}$ & & 8 & 3 & 2600 & Good \\
\hline $34 s$ & & 3 & 8 & 2700 & Good \\
\hline $34 \mathrm{~s}$ & & 3.5 & 3 & 2300 & Failed \\
\hline 345 & & 6.3 & 6 & 2000 & Failed \\
\hline $34 \mathrm{~S}$ & & 3.3 & 4 & 2900 & Failed \\
\hline $34 \mathrm{~s}$ & & 1 & 1 & 3000 & Failed \\
\hline $34 S$ & & 1.3 & 1 & 3000 & Failed \\
\hline $34 \mathrm{~S}$ & -169 & 0.9 & 3 & 3000 & Failed \\
\hline $34 \mathrm{~S}$ & -170 & 2 & 8 & 3000 & Good \\
\hline 345 & -163 & 0.1 & & 3180 & Failed \\
\hline
\end{tabular}


TABLE 13

\section{ARC-PLASMA TEST SCIEDULE ON 345 COATED Ta-10 W ALLOY}

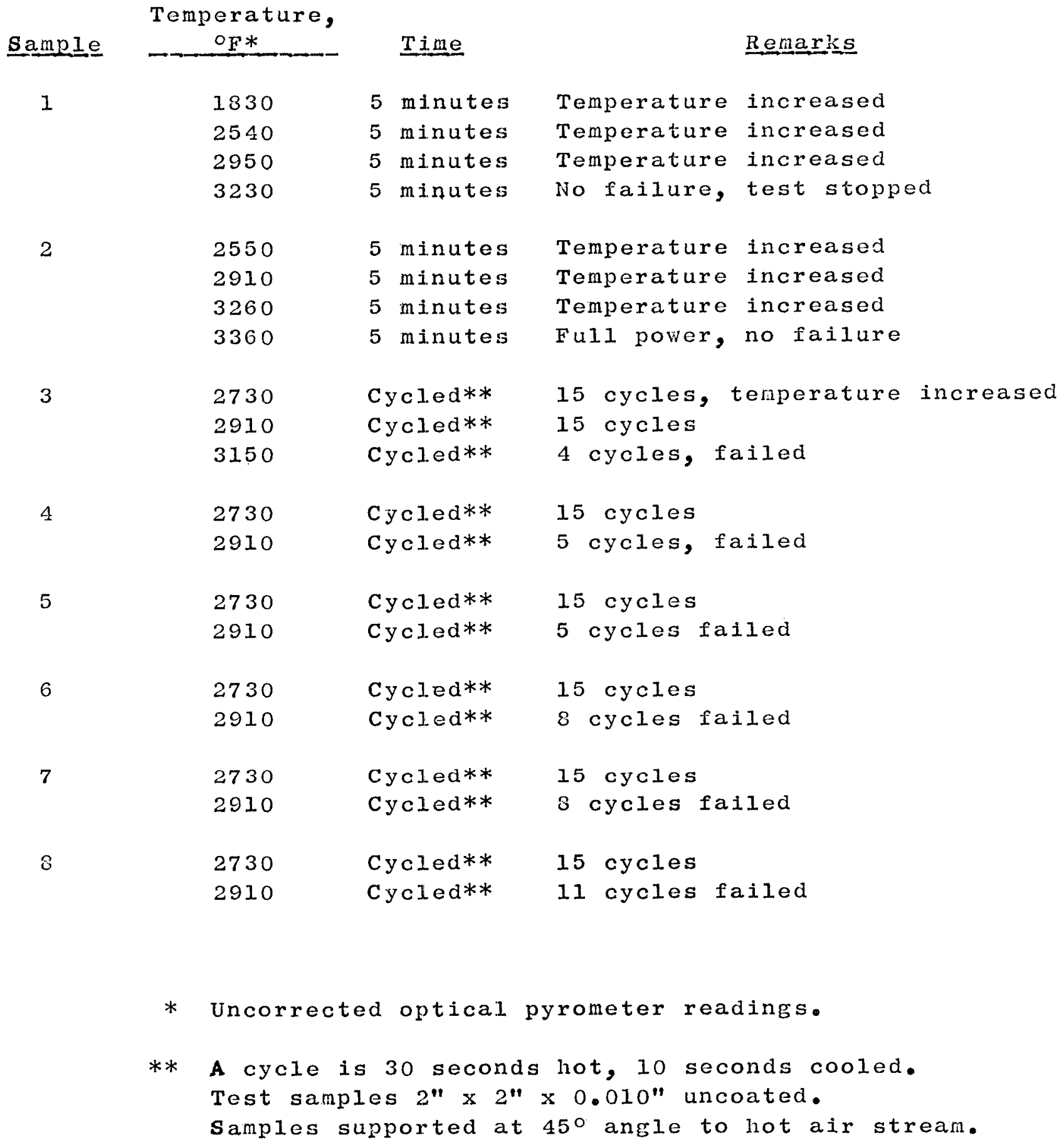


alloys. Oxidation results are summarized in Table 14. Once again the $34 \mathrm{~S}$ system seems to be the best up to and including $2500^{\circ} \mathrm{F}$. Around $2600^{\circ} \mathrm{F}$ and higher rapid reaction takes place between the $\mathrm{Bn}-$ Al coating and the substrate. $2500^{\circ} \mathrm{F}$ appears to be the maximum use temperature for $S \mathrm{n}-\mathrm{Al}$ coated columbium alloys.

\section{OTHER REFRACTORY METALB}

The 345 coating was tried on molybdenum and tungsten. Aroplasma, furnace, and flame test results are given in Table 15。 8 uch promising indications were not entirely expected. Metallographic examination of the tungsten does reveal grain boundary attack. But this coating system requires and deserves much more development work since only a few samples were prepared merely for feasiblilty indications:

\section{BERYLLIUM COATINGS}

It is known that the tantalum beryllides are oxidation resistant at and above $2500^{\circ} \mathrm{F}(3)$ The beryllides are: $\mathrm{TaBe}_{12}, \mathrm{Ta}_{2} \mathrm{Be}_{17}$, $\mathrm{TaBe}_{3}$, and $\mathrm{TaBe}_{2}$ 。 Therefure, coatings were applied to the tantalum materials by vapor deposition techniques. The samples ( 0.5 " $x$ $\left.0.75^{\prime \prime} \times 0.010^{\prime \prime}\right)$ were placed between powder rolled sheets of beryllium and vacuum heat treated. The beryllium sheet would ginter and could be used for many coating runs. The effect of coating conditions on thickness is given in Table 16. All four phases can be seen in the microstructure.

Early oxidation results on pure tantalum indicated that the coating was sengitive to thermal cycling since gross surface checking was noted on oxidized samples. It was apparent that berylilum coatings would confer the required oxidation resistance at $2500^{\circ} \mathrm{F}$ but that the difference in thermal expansion between the coating and the core should be matched more closely. Therefore, attempts were made to produce a lower beryllium content beryllide at the suriace before oxidation testing. Lower beryllides should have lower coefficients of expansion more compatible with that of tantalum. Tartalum samples, 0.010" thick, were vapor coated by two different heat treatments, 25 hours at $1800^{\circ} \mathrm{F}$ and 4 hours at $2000^{\circ} \mathrm{F}$. Half of each sample was then vacuum diffused for 25 hours at $2200^{\circ} \mathrm{F}$. The change in the zone thickness is reported in Table 17. Unfortunately, the same furnace was used for diffusion as for coating and 
TABLE 14

OXIDATION REBULTS ON COATED COLUMBIUM ALLOYB
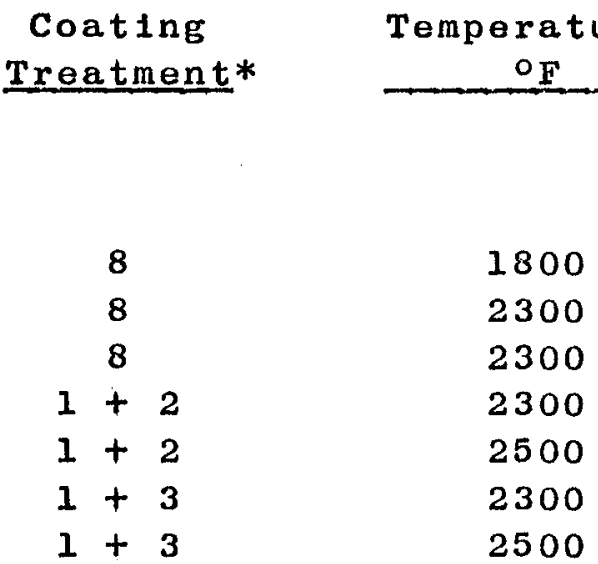

Time,

Treatment*

Hours

Cycles

Remarks

Pure Columbium

8
8
8
$1+2$
$1+2$
$1+3$
$1+3$

1800

1000

148

240

31

13

48

24

30

5

10

15

13

17

24

$\underline{B-22}$

8

8

8

8

7

7

7

5

5

5

6

6

6

7

7

7
$1+2$
$1+2$
$1+4$
$1+4$
$1+3$
$1+3$

1800

2300

2300

2500

2500

2500

2500

2300

2500

2500

2300

2500

2500

2500

2500

2500

2300

2500

2300

2500

2300

2500
1000

112

240

100

10

24

28

96

38

64

96

38

64

10

: 23

32

$\underline{E}=4 \underline{8}$

48

13

72

16

72

16

30
4
10
12
9
1
27
4
38
4
4
38
4
9
22
1

Excellent

Falled

Failed

Corner Failure

Corner Fallure

Good

Good

Excellent

Fatled

Falled

Good

Good

Edge Failure Good

Excellent

Excelient

Excellent

Excellent

Good

Good

Good

Fa1r

Fa1r

Fair

Very Poor

Good

Poor

Good

Good 
TABLE 14 (Cont'd.)

\section{OXIDATION RESULTS ON COATED COLUMBIUM ALLOYS}

Coating

Treatment*

\begin{tabular}{c}
$\begin{array}{c}\text { Temperatu } \\
\text { OF }\end{array}$ \\
\hline \\
2300 \\
2300 \\
2500 \\
2300 \\
2500 \\
2500
\end{tabular}

Time,

Hours Cycles

Remarks

\section{$\underline{F-48}$ (Cont'd.)}

$\begin{array}{rrrrr}5 & 2300 & 120 & 4 & \text { Poor } \\ 5 & 2300 & 24 & & \text { Poor } \\ 5 & 2500 & 7 & 7 & \text { Very Poor } \\ 6 & 48 & 2 & \text { Very Poor } \\ 6 & 2300 & 32 & 2 & \text { Very Poor } \\ 6 & 2500 & 7 & 7 & \text { Very Poor }\end{array}$

\section{* Coating Techniques}

1. Titanized 16 hours at $2280^{\circ} \mathrm{F}$ in vacuum。

2. Pack calorized for 4 hours in argon at $1900^{\circ} \mathrm{F}$ in a powder mix of $40 \%(\mathrm{Al}-11 \mathrm{Si}-10 \mathrm{Cr})-2 \% \quad \mathrm{NH}_{2} \mathrm{Cl}-58 \% \mathrm{Al}_{2} \mathrm{O}_{3}$ 。

3. Dipped for 30 seconds at $1900^{\circ} \mathrm{F}$ in $\mathrm{Al-10} \mathrm{Si}-10 \mathrm{Cr}$ and pack calorized for $l$ hour at $1900^{\circ} \mathrm{F}$ in argon in $90 \% \mathrm{Al}_{2} \mathrm{O}_{3}-10 \% \mathrm{AI}$ powders.

4. Dipped for 2 minutes at $1700^{\circ} \mathrm{F}$ in $\mathrm{Al-11} \mathrm{Si}$ and pack calorized.

5. Dipped for 15 seconds at $1900^{\circ} \mathrm{F}$ in AI-5 Cr-5 Ti and pack calorized.

6. Dipped for 15 seconds at $1900^{\circ} \mathrm{F}$ in Al-15 Cr-9 Si-5 Sn and pack calorized.

7. 365 .

8. 348 。

B-22 alloy is $\mathrm{Cb}-5$ Hf-1 Ti-1 $\mathrm{Zr}$, developed by Westinghouse under Air Force sponsorship. 
Table 15

OXIDATION RESULTS ON COATED MOLYBDENUM AND TUNGSTEN

\begin{tabular}{|c|c|c|c|c|c|c|}
\hline Coating & $\begin{array}{r}\text { Type of } \\
\text { Oxidation } \\
\text { Test }\end{array}$ & $\begin{array}{c}\text { Tempa, } \\
\text { OF } \\
\end{array}$ & \multicolumn{2}{|c|}{ Time } & Cycles & Remarks \\
\hline \multicolumn{7}{|c|}{ Molybdenum } \\
\hline 3.48 & Arc-Plasma & 2550 & 5 & $m i n$ 。 & & Temperature inoreased \\
\hline 345 & Arc-Plasma & 2910 & 5 & $\min$ 。 & & Temperature increased \\
\hline 348 & Arc-P lasma & 3270 & 5 & $\min$ 。 & & Temperature increased \\
\hline $34 \mathrm{~S}$ & Arc-Plasmá & 3450 & & & & Falled \\
\hline 348 & Arc-Plasma & 2550 & 5 & $\min$ & & Temperature increased \\
\hline 348 & Arc-Plasma & 2910 & 5 & $m \perp n$ 。 & & Temperature Increased \\
\hline 348 & Aro-Plasma & 3200 & 5 & $\mathrm{~m} 1 \mathrm{n}$ & & $\begin{array}{l}\text { No fallure, teat } \\
\text { stopped }\end{array}$ \\
\hline 348 & Furnace & 2500 & 46 & hrs。 & 5 & Good \\
\hline $34 S$ & Furnace & 2500 & 240 & hrs. & 11 & Edge failuro \\
\hline $34 \mathrm{~s}$ & Flame & 2730 & 20 & $m i n$ 。 & & Failed \\
\hline $34 \mathrm{~S}$ & Flame & 2820 & 120 & min。 & 4 & Good \\
\hline $34 S$ & Flame & 2910 & 5 & $\min$. & & Fatied \\
\hline $34 \mathrm{~S}$ & Flame & 3000 & 5 & $m i n$ 。 & & Failed \\
\hline $34 S$ & Flame & 3090 & 5 & $\min$ & & Failed \\
\hline $34 \mathrm{~S}$ & Flame & 3180 & 5 & min。 & & Failed \\
\hline $34 \mathrm{~s}$ & Flame & 3360 & 5 & $\min$ & & Falled \\
\hline 348 & Flame & 3270 & 33 & min。 & 3 & Failed \\
\hline 348 & Flame & 3180 & 26 & min. & 5 & Failed \\
\hline 348 & Flame & 3000 & 10 & hrs。 & 18 & Good \\
\hline $40 s$ & Flame & 3300 & 68 & $m i n$. & 5 & Good \\
\hline $40 s$ & Flame & 3400 & 51. & $\min$. & 4 & Failed \\
\hline
\end{tabular}

\section{Tungsten}

348

34.8

348

348

348

348
Arc-Plasma 2730

Arc-Plasma $\quad 2940$

Arc-Plasma $\quad 3090$

Arc-Plasma

Arc-Plasma

Flame
3260

3460

3450

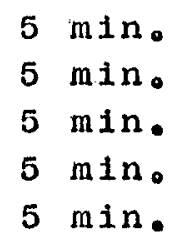

$60 \mathrm{~min}$.
Temperature Increased Temperature inoreased Temperature increased Temperature increased Failed

Good 
TABLE 16

METALLOGRAPHIC THICKNESS OF BERYLLIDE COATINGS

Coating Treatment

Time, Temp.,

Hours

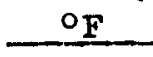

4

4

4

1

2

$\stackrel{\infty}{\infty}$

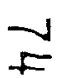

1
Alloy $\frac{\text { Thickness in mils (0.001") }}{\text { Coating core coating Total }}$ Remarks

$\mathrm{Ta}$

0.7

8.7

0.7

10.1

Good

1.8

9.2

$1.7 \quad 12.7$

Satisfactory

$10 \% \mathrm{~W}$

1.4

9.6

$1.7 \quad 12.7$

1.5

Good

Ta

$2 \cdot 6$

8.9

2.4

13.9

Good

$10 \% \mathrm{~W}$

2.2

8.8

2.1

13.1

Good

$\mathrm{Ta}$

1.4

9.8

1.4

12.6

Satisfactory

$10 \% \mathrm{~W}$

1.7

9.4

1.6

12.7

2.9

12.0

2.5

14.3

1.6

12.2

2.5

13.4

4.5

11.9 satisfactory

Good

Satisfactory

Satisfactory

Satisfactory

Oxidized at $2500^{\circ} \mathrm{F}, 93 \mathrm{hrs}$.

Tantalum uncoated 9.7 mils thick Ta-10\% W uncoated 10.4 mils thick 
TABLE 17

GROWTH OIF TANTALUM BERYLLIDES

Thickness in Mils $(0.001 ")$

\begin{tabular}{|c|c|c|c|c|}
\hline \multirow[b]{2}{*}{ Zone } & \multicolumn{2}{|c|}{ As Coated } & \multirow{2}{*}{$\begin{array}{l}\text { Vacuum Diffused } \\
\text { BeS1825VD2225 } \\
\end{array}$} & \multirow{2}{*}{$\begin{array}{c}2200^{\circ} \mathrm{F}, 25 \text { Hours } \\
\text { BeS 204VD2225 }\end{array}$} \\
\hline & $\mathrm{BeS} 1825$ & Bes 204 & & \\
\hline $\mathrm{TaBe}_{12}$ & 1.7 & 1.4 & 1.8 & 2.2 \\
\hline $\mathrm{Ta}_{2} \mathrm{Be}_{17}$ & 0.24 & 0.24 & 0.49 & 0.74 \\
\hline $\mathrm{TaBe}_{3}$ & 0.12 & 0.12 & 2.1 & 2.5 \\
\hline $\mathrm{TaBe}_{2}$ & 0.74 & 0.74 & 0.37 & 0.24 \\
\hline $\mathrm{Ta}$ & 8.6 & 8.7 & 4.2 & 4.2 \\
\hline $\mathrm{TaBe}_{2}$ & 0.74 & 0.74 & 0.24 & 0.24 \\
\hline $\mathrm{TaBe}_{3}$ & 0.12 & 0.12 & 2.2 & 2.1 \\
\hline $\mathrm{Ta}_{2} \mathrm{Be}_{17}$ & 0.24 & 0.24 & 0.71 & 0.74 \\
\hline $\mathrm{TaBe}_{12}$ & 1.6 & 1.7 & 1.9 & 2.7 \\
\hline TOTAL & 14.1 & 14.0 & 14.01 & 15.66 \\
\hline
\end{tabular}


additional beryllium was deposited on the samples. The effect of diffusion is obvious. Notable is the rapid growth of $\mathrm{TaBe}_{3}$. This technique was later found to be unnecessary and impractical.

Furnace oxidation results with different coating treatments for the Ta-10 $\mathrm{W}$ alloy are given in Table 13. Vapor depositing for 4 hours at $2000^{\circ} \mathrm{F}$ gave the best oxidation results. Requirements can be met at $2500^{\circ}$ and $2600^{\circ} \mathrm{F}$ and possibly at $27000^{\circ}$. Experimental difficulties were encountered at $2800^{\circ} \mathrm{F}$ where reactions were sometimes noted between the $\mathrm{Al}_{2} \mathrm{O}_{3}$ boat and/or platinum. Samples of Ta-10 W were resistant at $2500^{\circ}$ to $2800^{\circ} \mathrm{F}$ for 10 hours and 10 cycles under stresses producing 1 to $15 \%$ deformation. Pure tantalum samples stressed during exposure failed in minutes.

The same number of compounds reported to be in the Be-Ta system are found in the layers that comprise the coatings on tantalum, as shown in Figure 19. These layers can be resolved best under polarized light, which makes them optically active. Diffusion effects on core thickness are also illustrated in Figure 19. The coating is primarily TaBe 12 which on exposure to $2500^{\circ} \mathrm{F}$ or higher with pure tantalum causes rapid diffusion, the substrate receding approximately $0.004 "$ in 15 hours at $2500^{\circ} \mathrm{F}$. In Ta-10 W it is somewhat surprising that diffusion occurs much nore slowly. After 10 hours at $2800^{\circ} \mathrm{F}, 300$ degrees higher, surface recession was only $0.002 "$ after 10 hours. This is in contrast to the aluminide system where little difference in diffusion was found between the two substrate materials. Diffusion in the (Ta-lo W)-berylide system was somewhat faster than in the aluminide system. It should be noted that the original beryllium concentration gradient is much higher than with aluminum, thus providing more driving force for reaction. Major growth occurred in the $\mathrm{TaBe}_{3}$ layer at the expense of $\mathrm{TaBe}_{12^{\circ}}$ The $\mathrm{Ta}_{2} \mathrm{Be}_{17}$ layer also thickened and the $\mathrm{TaBe}_{2}$ layer remained relatively constant. Evidence of twinning was noted in the $\mathrm{TaBe}_{2}$ 。

No appreciable internal hardening effects were noted after exposure, an increase of $20 \mathrm{kHN}$ occurring in the pure tantalum after 15 hours at $2500^{\circ} \mathrm{F}$. The surface compounds are extremely hard, brittle, and difficult to maintain intact during metallographic polishing. All of them are over $1000 \mathrm{KHN}$ and as high as $1900 \mathrm{KHN}$.

\section{VII。 DISCUSSION}

Both the aluminide and beryllide systems have provided very interesting results in protecting pure tantalum and the Ta-lo W 
TABLE 18

FURNACE OXIDATION RESULTS ON BERYLLIDE COATED TANTALUM ALLOY

Temperature,

of

1300

1800

2200

2200

2500

2500

2500

2500

2500

2500

2600

2600

2600

2700

1800

2200

2200

2500

2500

2500

2500

2600

2600

2600

2600

2700

2700

2800

Time,

Hours

Cycles

Remarks

Coated 4 hours $1900^{\circ}$ F

4

23

3

4

1

1

6

7

16

21

1

5

16

16

2

6

7

4

Coated 2 hours $2000^{\circ} \mathrm{F}$

16

23

70

2

10

16

110

7

9

16

100

16

16

1
Failed

Failed

Failed

Failed

Failed

Failed

Good

Good

Good

Good

Failed

Failed

Good

Good
Failed

Failed

Failed

Failed

Good

Good

Good

Failed

Failed

Good

Good

Good

Failed

Boat Reaction 
TABLE 13 (Cont'd.)

FURHACE OXIDATION RESULTS ON BERYLLIDE COATED TANTALUM ALLOY

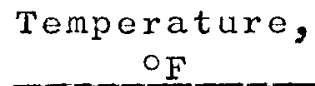

1000

2200

2200

2200

2500

2500

2500

2500

2500

2600

2603

2600

2700

2700

2000

2300

1000

2200

2200

2500

2500

2500

2600

2000

2600

2600
Time,

Houㅡㅁㅗ

Cyclesㅗㅡ

Remarㅡㄹㅗㅡ

Coated 4 hour

$\begin{array}{rr}7 & 1 \\ 27 & 3 \\ 7 & 2 \\ 64 & \\ 120 & 13 \\ 10 & 10 \\ 10 & 10 \\ 62 & 4 \\ 64 & \\ 93 & \\ 10 & 9 \\ 10 & 10 \\ 64 & \\ 7 & 6 \\ 16 & \\ 6 & 5 \\ 3 & 2\end{array}$

Coated 3 hours $2000^{\circ}$ F

$\begin{array}{rr}20 & 1 \\ 64 & \\ 104 & 14 \\ 10 & 10 \\ 24 & 23 \\ 64 & \\ 6 & 6 \\ 10 & 10 \\ 16 & \\ 65 & \end{array}$

Failed Good Good Good

Failed Good

Failed Good Good Good

Failed
Failed
Failed
Good
Failed
Good
Good
Failed
Good
Good
Good
Good
Good
Failed
Good
Reaction
at Reaction


TABLE 13 (Cont'd。)

FURNACE OXIDATION RESULTS ON BERYLLIDE COATED TAITALUM ALIOY

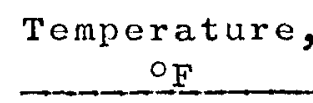

Time,

Hours.

Cycles

Remarkㅗㅗ

Coated d 4 hours 250. ${ }^{\circ} \mathrm{F}$

$$
\text { Ta-1으는 }-5 \text { W Alloy }
$$

2500

2500

2500

2700

2700

2700

$\begin{array}{rr}6 & 5 \\ 20 & 5 \\ 64 & \\ 6 & 5 \\ 16 & \\ <64 & \end{array}$

Good

Failed Good

Failed

Good

Failed 


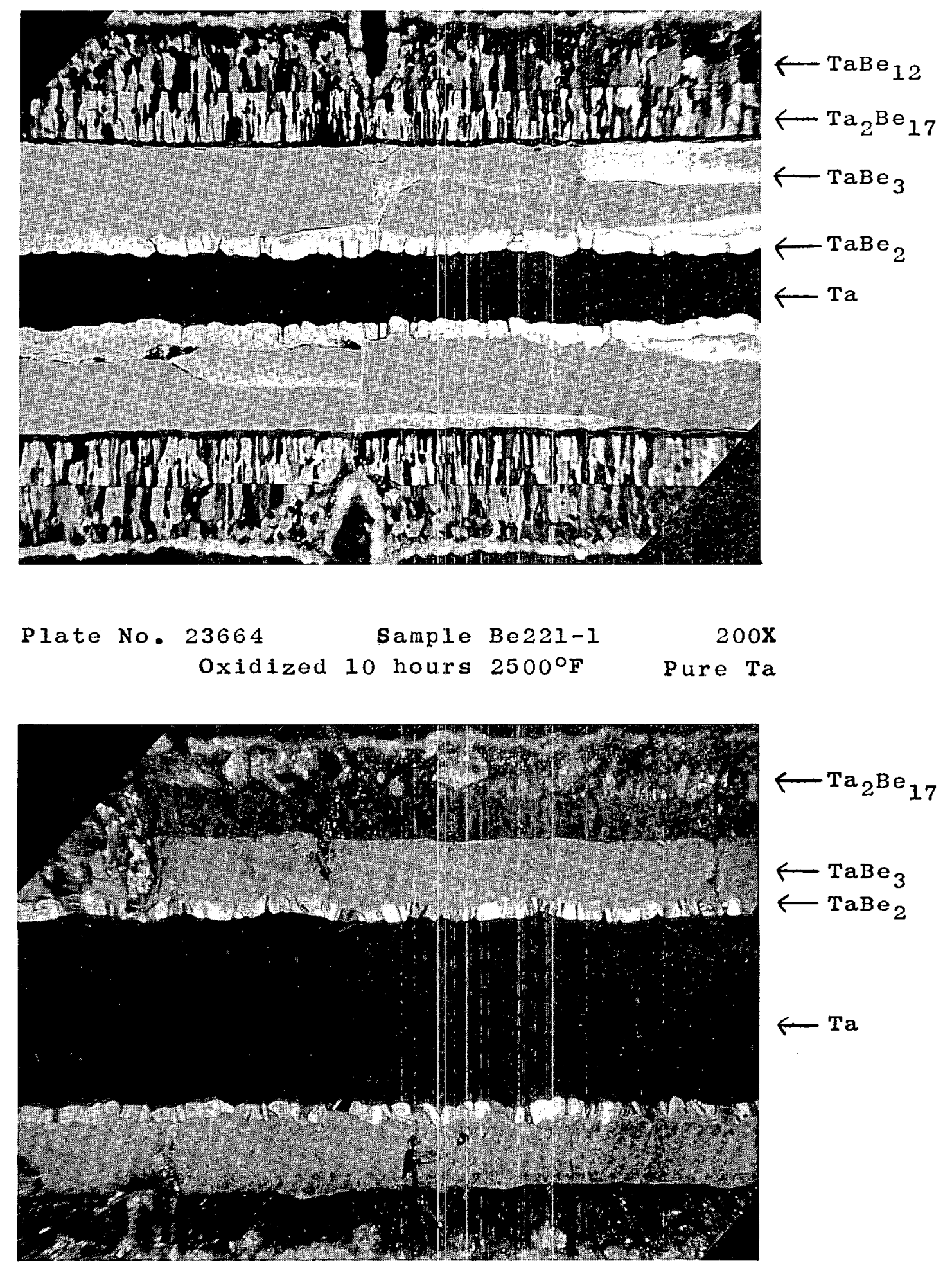

3664

Sample Be221-1

Pure Ta
Plate No. 23748
Sample TBeS204-4
$200 x$

Fig. 19. Beryllium coated samples after oxidation for ten hours. 
alloy sheet from air oxidation for 10 hours with thermal cycling at temperatures up to $2800^{\circ} \mathrm{F}$ or higher. Particular emphasis is laid on the $S_{n}-A 1$ system since it is so simple and practical to use and appears to have considerable flexibility of application. It is also very reliable over a broad temperature range and shows evidence of self-healing characteristics and resistance to abuse in handling after coating.

The role of tin is hard to define and considerable investigative work could be done in tracing the migration and concentration of tin-aluminum in and through the several coating layers. It is also difficult to explain the mechanism of repletion of the protective $\mathrm{Al}_{2} \mathrm{O}_{3}$ îlm and whether or not the oxide is the sole means of protection; it certainly appears to be.

Samples of the Ta-10 W alloy coated with $34 \mathrm{~S}$ have been investigated by $\mathrm{x}$-ray diffraction techniques. As coated the structure is mainly $\mathrm{TaAl}_{3}, \mathrm{Al}, \mathrm{Sn}$, and some amounts of $\mathrm{Ta}_{2} \mathrm{Al}_{\mathrm{A}} \mathrm{A}$ sample after being oxidized for 64 hours at $2700^{\circ} \mathrm{F}$ contained an $\mathrm{Al}_{2} \mathrm{O}_{3}$ surface film. Grinding off successive layers revealed mostly $\mathrm{Ta}_{2} \mathrm{Al}$ plus $\mathrm{Al}_{2} \mathrm{O}_{3}$ and beta tin. These structures corroborate the phases seen in the microstructure。

A suggested mechanism for oxidation protection of tin-aluminum coated tantalum could be the following. An absolute necessity is the presence of $\mathrm{TaAl}_{3}$ during initial exposure to oxidizing conditions. Many samples of $\mathrm{Ta}, \mathrm{Ta}-10 \mathrm{~W}$ and $\mathrm{Ta}-10 \mathrm{Hf}-5 \mathrm{~W}$ during or after coating have been heated to $2000^{\circ} \mathrm{F}$ or higher under non-oxidizing conditions. In every case oxidation failure is immediate. In the later case before oxidation all or most of the TaAl has been converted to $\mathrm{Ta}_{2} \mathrm{Al}$. This compound has no oxidation resistance。 These data prove the first premise. After the TaAl 3 has formed an $\mathrm{Al}_{2} \mathrm{O}_{3}$ oxide layer and been converted to $\mathrm{Ta}_{2} \mathrm{Al}$ by diffusion during oxidation, enough Al (less than $5 \%$ ) is dissolved in the tin from

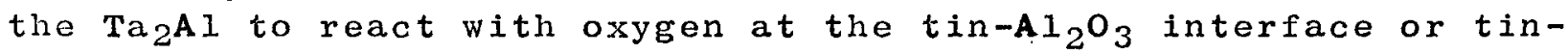
air interface, causing growth of the $\mathrm{Al}_{2} \mathrm{O}_{3}$ layer or to heal any defect in the oxide. There is no indication of the $\mathrm{Al}_{2} \mathrm{O}_{3}$ being formed at the $\mathrm{Ta}_{2} \mathrm{Al}$ interface and floating through the $t$ in to the oxide layer. The small solubility of Al in the $s$ must confer the self-healing characteristics. Tin-free aluminum compositions such as G-14 do not have this ability. Whenever the $\mathrm{Al}_{2} \mathrm{O}_{3}$ layer is broken by thermal shock, etc., the oxygen can react with $\mathrm{Ta}_{2} \mathrm{Al}$ and cause immediate failure without healing the oxide. This theory seems to explain all observed oxidation phenomena with pure Ta and the Ta-10 W alloy. A similar explanation can be used for the 
ability of Sn-Al coating to protect certain columbium alloys. Although $\mathrm{CbAl}_{3}$ is much more thermally stable than $\mathrm{TaAl}_{3}$, it does have a finite life at $2500^{\circ} \mathrm{F}$.

A harmful unknown phase is present in the Sn-Al coated Ta-10 Hf-5 W alloy. Therefore, it may be preferable to use a NavyWestinghouse developed Ta alloy, Ta-8 W-2 Hf, since it has equal high temperature properties and preliminary results at sylcor have shown it can be coated successfully. This is probably due to the lower hafnium content。

It is not suggested that the 50 sn-50 Al coating composition is the best for tantalum alloys. Chemical analysis of the 34 s coating after diffusion shows that $34 \%$ Al is still present in the Sn-Al phase. The Al can still react with Ta to form Ta-Al compounds. Good results were obtained with initial tests of the 408 composition (75 Sn-25 Al) which has less aluminum. Core regression should be less than with the $34 \mathrm{~s}$ coating. Possibly even better would be: (1) a first coat of Sn-25 Al, (2) diffuse, and (3) a second coat of Sn-10 Al and diffuse. The variations are almost infinite。A duplex coating technique seems to be required. The reason is not known but may be associated with reliability of more complete coverage。

The tantalum-beryllium system also merits more work, since BeO has a higher melting point than $\mathrm{Al}_{2} \mathrm{O}_{3}{ }^{\circ} \mathrm{A}$ diluent should be found for the beryliides similar to tin with the aluminideso Although diffusion effects are more rapid with beryllium, tungsten alloying appears to slow down the process and give hope that additions higher than $10 \%$ would be even more effective. It is recognized that elevated temperature oxidation rates of the beryllides is adversely affected by moisture(5). However, the refractory nature of $\mathrm{BeO}$ and the possible gains in protectiveness make it attractive for further study along the lines suggested.

\section{VIII。 SUMMARY}

The objectives of this program were met and surpassed. Aluminides were produced on tantalum materials that would protect the core from oxidation for a minimum of 10 hours with 10 thermal cycles from test temperature to ambient under a stress producing at least $2 \%$ elongation without failure. A dipped and diffused coating of Al-5 Ti-5 Cr (G14) would give 10 hours with 10 cycles protection in the range $2500^{\circ}$ to $2700^{\circ} \mathrm{F}$ to ambient. Lower temperature properties 
were relatively poor. A $90 \mathrm{Sn}-10$ Al (G21) dip coating would meet these same requirements up to $2600^{\circ} \mathrm{F}$ without the poor low temperature phenomenon. The duplex spray coating of 50 Sn-50 AI ( $34 S$ ) would protect tantalum and the Ta-lo W alloy up to 100 hours with 100 cycles to $2300^{\circ} \mathrm{F}$. No anomalous behavior was found between $-320^{\circ} \mathrm{F}$ to $3000^{\circ} \mathrm{F}$ or possibly $3400^{\circ} \mathrm{F}$ with this coating. Diffusion appears to be a problem with Ta-10 Hf-5 W. The $34 \mathrm{~S}$ coating on the Ta-10 W alloy can withstand high velocity hot air streams for reasonable times.

Feasibility of $34 \mathrm{~S}$ protection was shown for a columbium alloy, molybdenum, and tungsten。

Good protection was obtained with beryllide coatings on Ta-10 $W$ in the range of $2500^{\circ}$ to $2700^{\circ} \mathrm{F}$. Samples behaved poorly in the range $1300^{\circ}$ to $2200^{\circ} \mathrm{F}$. Brittleness of the beryllides seems to be the main problem with this type coating.

\section{REFERENCES}

1. F. F. Schmidt, et al, "Investigation of the Properties of Tantalum and its Alloys", WADD Technical Report 61-lo6, March, 1961 。

2. F. Fo Schmidt, et al, "Investigation of the Properties of Tantalum and its Alloys", WADD Technical Report 59-13, December, 1959 。

3. R. M. Paine, A. J. Stonehouse, and W。W。 Beaver, "An Investigation of Intermetallic Compounds for Very High Temperature Applications", WADC Technical Report 59-29, Part I, January, 1960, and Part II, July, 1960 。

4. Private communication with University of Dayton Research Institute personnel。

5. J。R. Lewis, "Evaluation of Beryllides", Journal of Metals, May, 1961, Vol。13, No。5, pp. 357-362。 